UNIVERSIDADE DE SÃO PAULO

FACULDADE DE FILOSOFIA, LETRAS E CIÊNCIAS HUMANAS PROGRAMA DE PÓS-GRADUAÇÃO EM GEOGRAFIA HUMANA

TUWILÊ JORGE KIN BRAGA

\title{
A territorialidade do corpo negro na USP
}

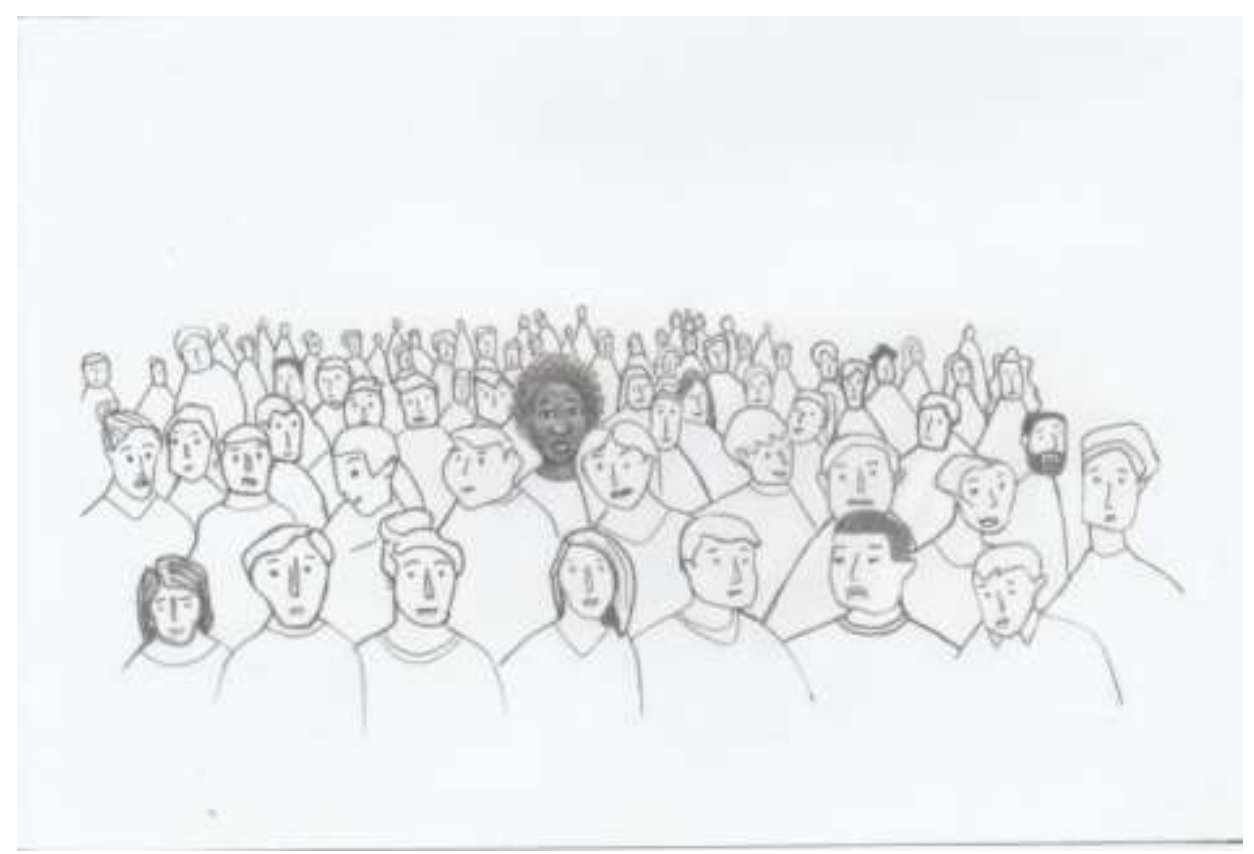

São Paulo

2019 
TUWILÊ JORGE KIN BRAGA

\section{A territorialidade do corpo negro na USP}

\section{Versão Corrigida}

Dissertação apresentada ao Programa de Pós-Graduação em Geografia Humana da Faculdade de Filosofia, Letras e Ciências Humanas para obtenção do título de Mestre em Geografia.

Orientador: Prof. Dr. Francisco Capuano Scarlato 
Autorizo a reprodução e divulgação total ou parcial deste trabalho, por qualquer meio convencional ou eletrônico, para fins de estudo e pesquisa, desde que citada a fonte.

Braga, Tuwile Jorge Kin

Bt

À territorialidade do corpo negro na USP / Tuwilé Jorge Kin Braga ; orientador Francisco Capuano Scarlato. - Săo Paulo, 2019.

$134 \mathrm{f}$.

Dissertaçăo (Mestrado) - Eaculdade de Filosofia, Letras e Ciências Humanas da Universidade de São Paulo. Departamento de Geografia. Area de concentração: Geografia Humana.

1. Geografias Negras. 2. territorialidade. 3. território. 4. USP. 5. relaçōes raciais. I. Scarlato, Francisco Capuano, orient. II. Titulo. 
Q2. fflch universidade de são paulo

FACULDADE DE FLOSOFIA, LFTRAS E CIÉNCIAS HUMANAS

\section{ENTREGA DO EXEMPLAR CORRIGIDO DA DISSERTACĀO/TESE}

Termo de Ciência e Concordância do (a) orientador (a)

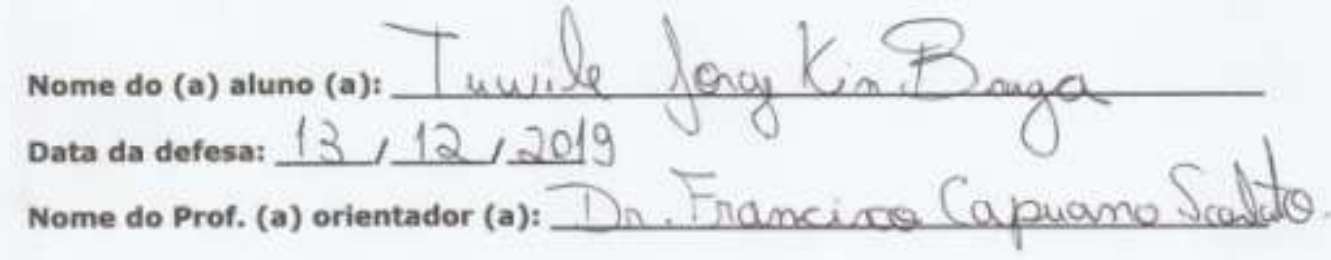

Nos termos da legislaçăo vigente, deciaro ESTAR CIENTE do conteúdo deste EXEMPLAR CORRIGIDQ elaborado em atençẫo d̀s sugestōes dos membros da comissăo Julgadora na sessão de defesa do trabalho, manifestando-me plenamente favorável ao seu encaminhamento e publicaçāo no Portal Digital de Teses da USP.

Săo Paulo, $\mathrm{AH} / \mathrm{2} / 2 \mathrm{2}$

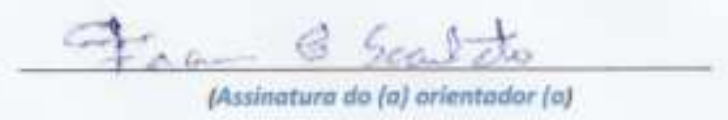


BRAGA, Tuwilê Jorge Kin. A territorialidade do corpo negro na USP. 2019. 134f. Dissertação (Mestrado em Geografia) - Faculdade de Filosofia, Letras e Ciências Humanas, Universidade de São Paulo, São Paulo, 2019.

Aprovado em : 13/12/2019

\section{Banca Examinadora}

Prof. Dr. Salomão Jovino da Silva - Faculdade Santo André (FSA)

Julgamento: Aprovado

Prof. Dra. Geny Ferreira Guimarães - Universidade Federal Rural do Rio de Janeiro (UFRRJ)

Julgamento: Aprovado

Prof. Dra. Glória da Anunciação Alves - Universidade de São Paulo (USP)

Julgamento: Aprovado

São Paulo

2019 
À minha mãe, por ser exemplo de luta. 


\section{AGRADECIMENTOS}

$\mathrm{O}$ ato de agradecer deveria ser sinônimo de fartura pela grandeza sentida por aquele que retribui e, nessa escrevivências minha - que não é somente minha, como diz o querido Alex Ratts, tenho muitos a agradecer.

Primeiramente, agradeço àqueles que não vejo, mas sinto, e que me acompanham muito antes de ser o que sou. Por isso, agradeço aos Orixás e a todas as entidades por alimentarem minha alma de esperança nos momentos mais difíceis.

À minha mãe, Maria do Carmo Lima, por me fazer olhar para dentro de mim e me permitir me inspirar em sua potência para concluir este trabalho. Não foi fácil, mas conseguimos. Me considero um "Preto tipo A" graças a você.

À Mirella A.S Maria, minha noiva, meu amor, que esteve ao meu lado e me ajudou a conseguir escrever este trabalho. Companheira de todas as horas, não deixou minhas mãos a sós e plantou a confiança que me fez colher este mestrado.

À minha querida irmã Tainara Ngabile que quantificou os números que, em muitos momentos, se ofuscavam na minha frente.

À minha querida Tia Ângela Lima, que foi uma das minhas referencias enquanto servidora da Universidade de São Paulo e que, ao longo da pesquisa, trouxe aconchego em palavras mas também morada, permitindo o suporte em tempos difíceis.

Ao Núcleo de Pesquisadores(as) Negros(as) da Geografia (NEPEN-USP) que, nas diversas reuniões no Laboratório de Geografia Urbana, trouxe para minha escrita um olhar enegrecido da Geografia. Ainda sobre o Nepen, é preciso dar nomes a esses(as) protagonistas: Geinne Monteiro, Ricardo Oliveira dos Santos, Fabiana Luz (Fabi), Beatriz Pereira Silva, Celso Oliveira Jr., Amanda Moraes, Tailane Machado, Ana Lígia, Ayana, Felipe Ricardo Lopes, Érica Ferreira, Guilherme Estevão, Billy Malachias, Renato Ribeiro, Rita de Cássia, Everton Apolinário, Igor Santos Valvassori, Jennifer Tarriaga e Isadora Almeida Simões - esses três últimos tiveram uma aproximação muito forte no processo de construção deste trabalho.

À Jennifer Tarriaga e à Darliane Oliveira Santos, que decodificaram a cartografia do trabalho e materializaram os mapas que foram inseridos no mestrado; ao Igor, um grande camarada e irmão, que tirou todas as pedras da burocracia acadêmica e deu um caminho mais 
palpável para prosseguir; à Isadora, a grande ilustradora do meu mestrado, que permitiu a leitura visual das vozes negras deste trabalho.

A todos(as) trabalhadores(as) e estudantes negros(as) que participaram das entrevistas, cujas narrativas sobre o território da USP foram de suma importância, com negras vozes que acarretaram para a escrita geográfica um outro TOM. Cada encontro trouxe um aprendizado fraterno de como é ser negro(a) na USP.

Ao Prof. Dr. Francisco Capuano Scarlato pela oportunidade de desenvolver este projeto tão caro para mim. Suas sugestões e críticas alimentaram ainda mais minha vontade de lutar por uma universidade múltipla de saberes.

Por fim, àqueles que não vieram àqueles que já partiram e àqueles que virão. 


\section{RESUMO}

O presente trabalho busca fazer uma análise territorial da USP-Butantã a partir da perspectiva do corpo negro dos(as) servidores(as) e estudantes de graduação que ocupam esse campus. Pensamos, assim, as territorialidades desses sujeitos como caminho para interpretações das relações raciais e espaciais desiguais e da luta antirracista que se materializam ora em dados quantitativos, ora em dados simbólicos provenientes de narrativas que revelam um conteúdo caracterizado por múltiplas vivências negras no interior da universidade. Para isso, nos ancoramos no método de Milton Santos para compreender o viés do corpo, da individualidade e da cidadania e dos movimentos de luta e de solidariedade que estão presentes na Universidade de São Paulo.

Palav ras-chave: USP; Corpo Negro; Território; Territorialidade; Geografias Negras. 


\begin{abstract}
The present work seeks to make a territorial analysis of USP-Butantã through the perspective of black public servers and black undergraduate students who occupy this space. Thus, we think of the territoriality of these subjects as a way for interpretations of unequal racial and spatial relations and of the antiracist struggle, materialized by quantitative data and qualitative data from narratives that reveal a content characterized by multiple black experiences inside the university. In order to do this, we based this research on the Milton Santos' method to understand in the aspect of the body, individuality and citizenship and of the movements of struggle and solidarity present at the University of São Paulo.
\end{abstract}

Key-words:USP; Black Body; Territory; Territoriality; Black Geographies. 


\section{LISTA DE GRÁFICOS}

Gráfico 1 - Distribuição étnico-racial dos estudantes da USP - Butantã..............................55

Gráfico 2 -Total de estudantes negros e brancos em 2018 na USP - Butantã. .......................57

Gráfico 3 - Distribuição étnico-racial por gênero na USP - Butantã (2018) ..........................57

Gráfico 4 -Espaços ocupados pelos estudantes ne gros na USP - Butantã (2018) ..................61

Gráfico 5 - Comparação entre negros e brancos na Escola Politécnica (2018) ......................62

Gráfico 6 -Espaços ocupados por alunas ne gras na USP - Butantã (2018) ..........................63

Gráfico 7 - Configuração étnico-racial dos(as) servidores(as) da USP no campus Butantã...64

Gráfico 8 -Total de servidores/as negro(as) por espaço ocupado no território da Cidade

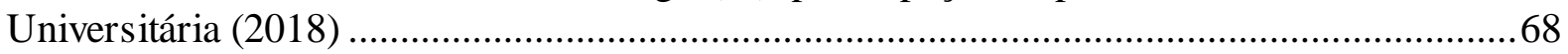

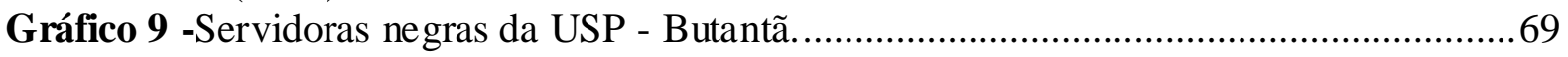

Gráfico 10 -Cargos dos servidores(as) negros(as) da USP - Butantã .................................. 71

Gráfico 11 -Cargo das mulheres ne gras na USP - Butantã ................................................. 73

Gráfico 12 -Cargo de servidores ne gros e de servidores brancos .........................................74

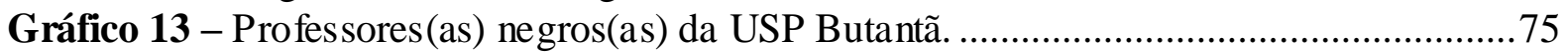

Gráfico 14 -Cargos dos três pontos quentes do território da USP Butantã. ............................76 


\section{LISTA DE FIGURAS}

Figura 1 - Carteira de identificação de funcionário da USP......................................... 15

Figura 2 -Mapa do território da Cidade Universitária. .......................................................18

Figura 3 -Mapa de distribuição da densidade de estudantes negros(as) na USP-Butantã em 2018.

Figura 4 -Espaços ocupados pelos servidores negros/as no território da USP (2018). .........66

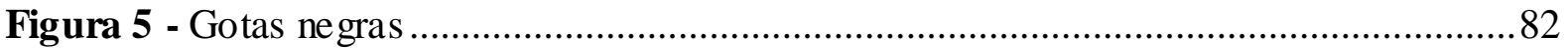

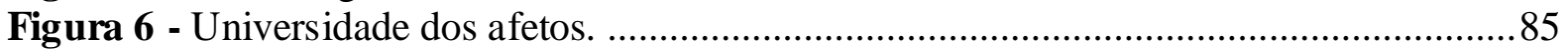

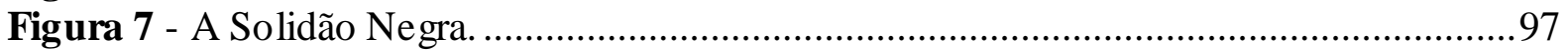

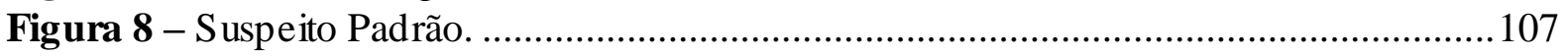

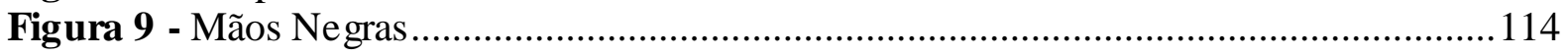

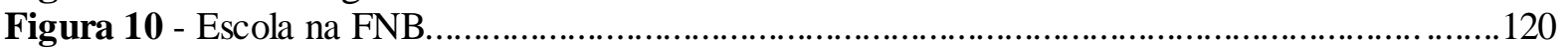

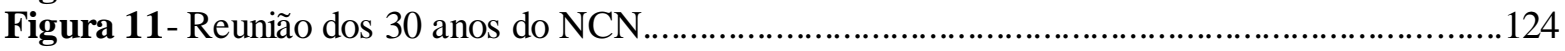

Figura 12 - Protesto a favor da implantação de cotas raciais na USP. ................................133 


\section{LISTA DE SIGLAS}

CEPEUSP - Centro de Práticas Esportivas da USP

CRUSP - Conjunto Residencial da USP

ECA- Escola de Comunicações e Artes

EP - Escola Politécnica

EEFE- Escola de Educação Física e Esporte

FAU - Faculdade de Arquitetura e Urbanismo

FCF- Faculdade de Ciências Farmacêuticas

FEA - Faculdade de Economia, Adminis tração e Contabilidade

FE - Faculdade de Educação

FFLCH - Faculdade de Filosofia, Letras e Ciências Humanas

FO- Faculdade de Odontologia

FUVEST - Fundação Universitária para o Vestibular

IAG - Instituto de Astronomia, Geofísica e Ciências Atmosféricas

ICB - Instituto de Ciências Biomédicas

IF- Instituto de Física

IBGE- Instituto Brasileiro de Geografia e Estatística.

IGC- Instituto de Geociências

IP - Instituto de Psicologia

IME- Instituto de Matemática e Estatística

IO - Instituto Oceanográfico

IQ - Instituto de Química

IRI - Instituto de Relações Internacionais 


\section{SUMÁRIO}

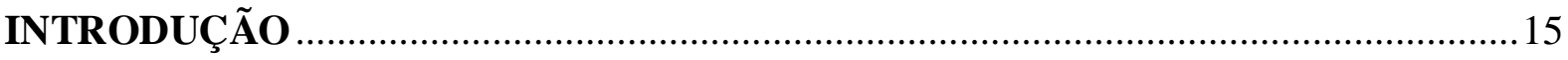

Levantando questões para entender o negro dentro da USP ...........................................19

Organizando os caminhos e estruturando o corpo do trabalho .........................................24

CAPÍTULO 1 - O te rritório da USP e a territorialidade do corpo negro ........................29

1.1 Entendendo conceitos: território, territorialização e territorialidade .............................29

1.2 Raça e racismo nas fronteiras do corpo negro brasileiro .............................................. 36

1.3 Limites distintos: reflexões sobre o negro na cidade de São Paulo .............................41

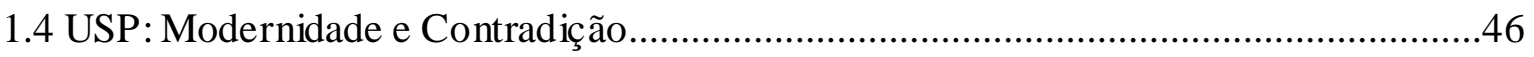

1.5 A configuração do corpo negro no território da USP ..................................................53

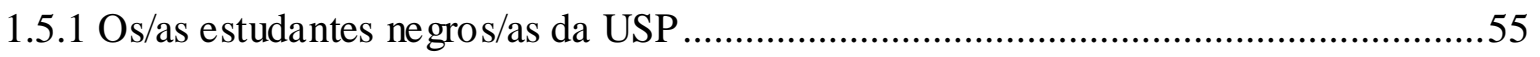

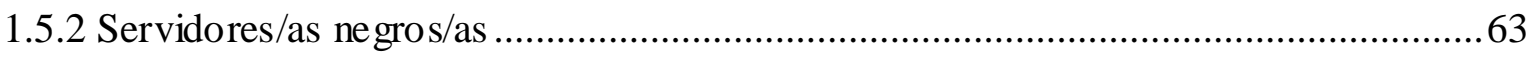

CAPÍTULO 2 - A individualidade da comunidade negra........................................... 78

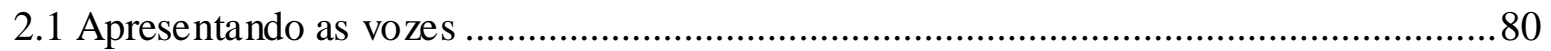

2.2 A trajetória diferenciada e os caminhos que se entrecruzam ..................................... 82

2.2.1 Tornando-se parte da USP como estudante ......................................................... 89

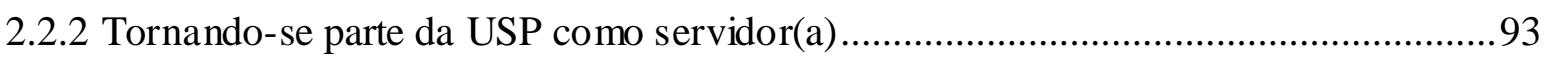

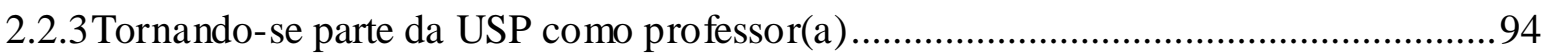

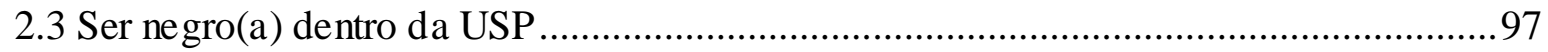

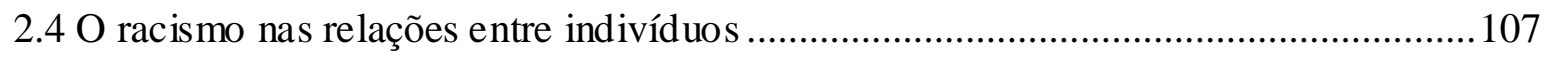

CAPÍTULO 3 - A cidadania e a população negra da USP ......................................... 117

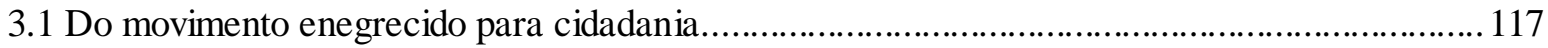

3.1.1. Um olhar sobre o NCN, outro para a cidadania .................................................................123

3.2 As cotas como instrumento de inc lusão do território ...................................................1235

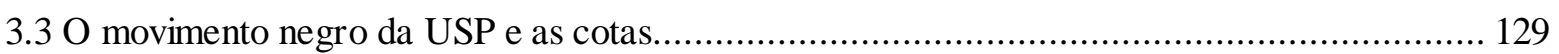

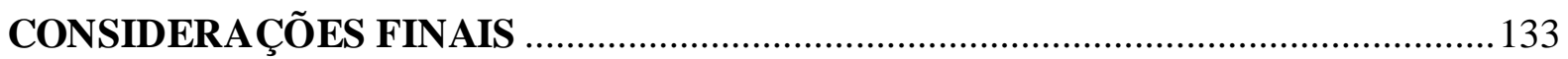

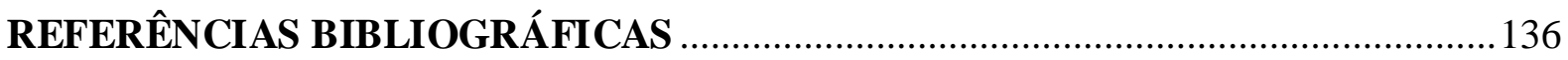




\section{INTRODUÇÃO}

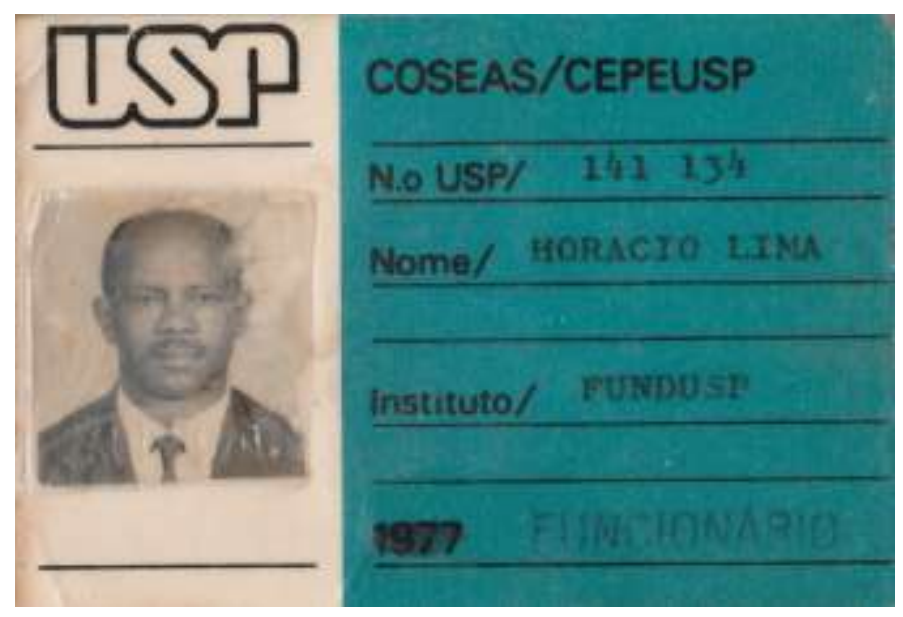

Figura 1 - Carteira de identificação de funcionário da USP. Fonte: Arquivo pessoal do pesquisador

Seu Horácio Lima, meu avô, funcionário do Fundo de Construção da Universidade de São Paulo (FUNDUSP) em 1979, teve parte de sua trajetória marcada como um operário que construiu o que é hoje uma das maiores universidades do mundo, a USP. Seu número de registro não nega que esse servidor foi parte de um conjunto de outros sujeitos que tiveram uma história dentro dos limites que margeiam a universidade. Seu cotidiano nesse espaço foi ditado pelo movimento do trabalho, levantando colunas e vigas que, posteriormente, seriam apropriados por inúmeras pessoas (inclusive, eu, o primeiro da família) ao longo do desenvolvimento da instituição. Apesar de sua relevância na construção do campus, sua trajetória social como servidor negro e homem negro não é uma informação revelada em documentos oficiais da universidade, pois suas especificidades e problemáticas são ocultadas na pequena foto preto e branco de sua carteirinha do COSEAS/CEPEUSP, sob o registro do $n^{\circ} 141134$.

Essa breve narrativa marca uma crítica desenvolvida em meu percurso como estudante de Geografia: compreender como a população negra tem ocupado determinados espaços da sociedade. Em se tratando de espaços universitários, esse questionamento se soma à agenda do movimento negro, caracterizado há anos por um profundo debate sobre a baixa presença 
de estudantes negros(as) nas universidades públicas brasileiras. Essa limitada densidade de estudantes negros(as), constatada na geografia da universidade, nos permite ter uma perspectiva que avalia que esse grupo étnico não apenas tem uma presença reduzida, como também esta é invisiblizada. Contudo, esse mesmo segmento também territorializa a instituição com usos e práticas que não se restringem necessariamente à sala de aula, como é o caso do seu Horácio, meu avô.

Refletindo sobre essa dimensão, tive, em 2013, a oportunidade de desenvolver um trabalho sobre os servidores negros da Universidade Federal de Viçosa, no qual foram analisadas as múltiplas territorialidades desses(as) trabalhadores(as) na Universidade Federal de Viçosa, na Zona da Mata mineira. Na época, o trabalho teve um resultado importante para as discussões étnico-raciais da Federal de Viçosa, já que possibilitou tirar da invisibilidade, a partir do levantamento de dados, sujeitos que tiveram participação no desenvolvimento de diversas práticas dentro desse território universitário.

No caso da USP, é possível compreender que, pela sua escala de participação nacional, uma proposta mais ousada de estudo se faz necessária para analisar seu território sob a ótica da população negra. Sendo assim, apropriando-se das dimensões dos sujeitos e de suas trajetórias, buscamos entender as relações e contradições de territorialidade e territorialização que englobam as especificidades da população negra que ocupa o território da Cidade Universitária (Fig. 1).

Esse espaço que ora é chamado de campus Butantã, ora de Cidade Universitária, foi fundado em 1956, no governo Jânio Quadros, concentrando uma gama de faculdades, escolas, institutos, museus e inclusive uma prefeitura, que fazem deste lugar uma importante esfera de análise no que diz respeito às suas diversas estruturas de funcionamento. Às margens do rio Pinheiros e murada em todas as suas partes, esse território universitário é parte de uma outra importante cidade - a de São Paulo - e dialoga com as contradições sociais e raciais que são produto de ideologias que se mantêm e se ressignificam ao longo do tempo e do espaço.

Nesse sentido, a associação do campus com a ideia de cidade foi um dos motivos que aguçaram a reflexão sobre sua formação territorial e se esta teria a mesma lógica da construção espacial de uma cidade que, historicamente, não contempla os grupos ditos minoritários (CAMPOS, 2005). Coube, então, pensar em que grau a USP tem pertencido a 
esses grupos socialmente desprivilegiados e, ao mesmo tempo, compreender os vínculos que eles possuem simbolicamente com o território do campus Butantã.

Foi, assim, realizado um mergulho de fôlego e que amadureceu ao longo do desenvolvimento do trabalho; porém, não foi um mergulho solitário. Graças às incansáveis trocas de conhecimento com o Núcleo de Estudantes e Pesquisadoras Negras da Geografia da USP (NEPEN-USP), foi possível contar com diversas contribuições bibliográficas e suas discussões e com aquilo que a escritora Conceição Evaristo chama de "escrevivências", em que, no nosso caso, as tramas são narradas e costuradas pelos protagonistas "(geo)grafados", pelos sujeitos negros que espacializam de diferentes formas o território do campus Butantã, registrando, em dados e narrativas, as problemáticas existentes em um país escravocrata (MOURA, 2014), como é o caso do Brasil.

A materialização deste mestrado, além de retomar a questão étnico-racial brasileira, objetiva, portanto, trazer a primazia da contribuição espacial na leitura teórica sobre o corpo negro no território da USP e assim levantar questões para entendermos as disparidades simbólicas e estruturais que movimentam significados dentro da universidade. 
Figura 2 - Mapa do território da Cidade Universitária.

Localização da Cidade Universitária Armando de Salles Oliveira (CUASO)
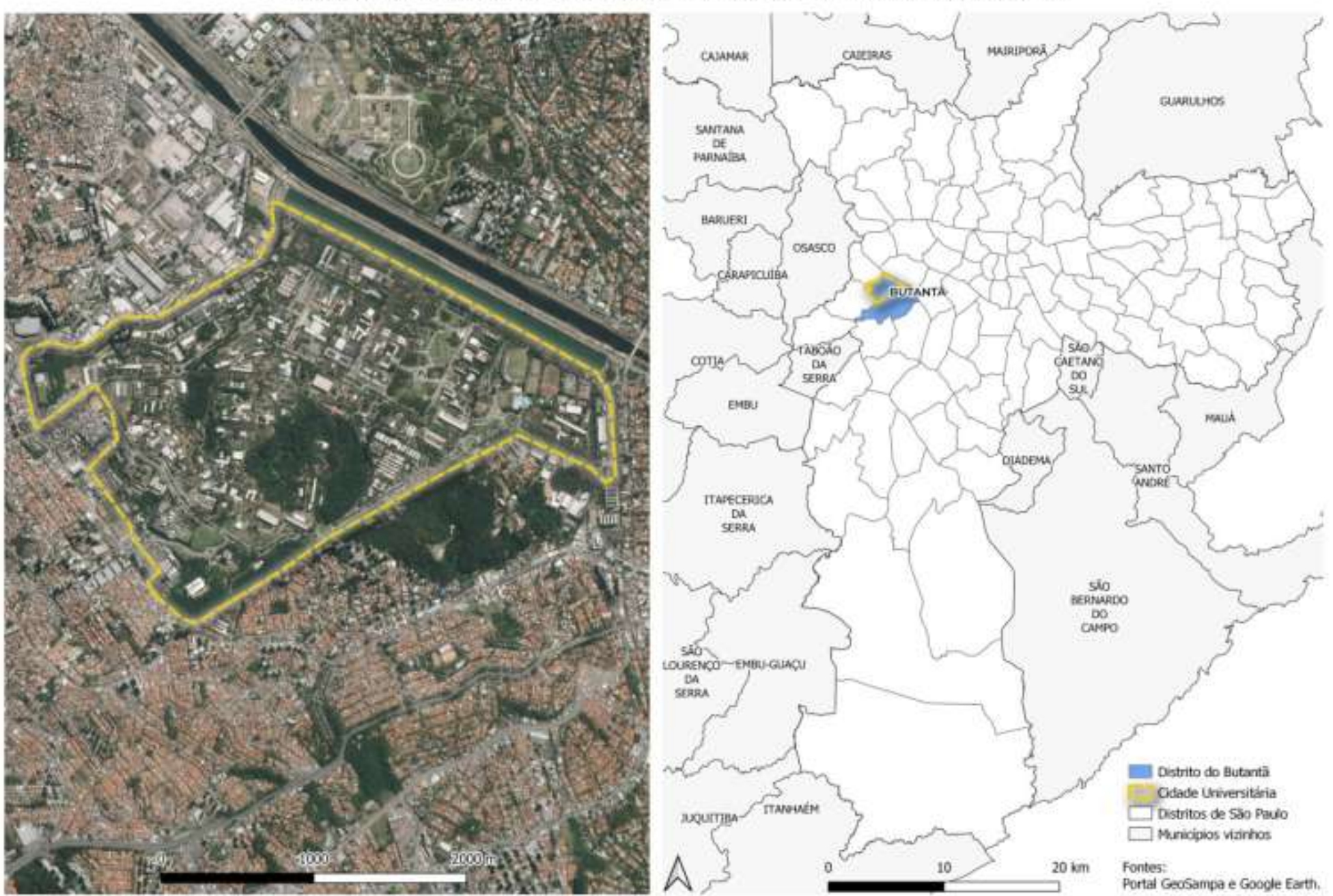

Fonte: Elaborado pelo autor (2018). 


\section{Levantando questões para entender o negro dentro da USP}

Por muito tempo, os estudos que versam sobre a Universidade de São Paulo estiveram - e ainda têm sido - pautados por uma leitura jurídico-política ${ }^{1}$ desse espaço, ou seja, a universidade é vista como um espaço de poder para a manutenção da sociedade. Porém, ao ser um espaço tão privilegiado quanto problemático, como nos lembra Boaventura (2012), a instituição também é palco de movimentos contraditórios derivados de reflexos sociais que, de forma direta ou indireta, dialogam com uma gama de situações que estão presentes nesse lugar.

A Universidade de São Paulo (USP), umas das principais universidades do Brasil, está relacionada, desde a sua fundação, em 1934, a uma tradição jurídico-política. Seu espaço diz respeito a uma importância territorial, a um "projeto político e cultural" (WITTER, 2006, p. 25) que não somente serve como forma de demonstrar o poder cientifico produzido por intelectuais representados pelo estado de São Paulo, como também para elevar o progresso nacional:

É inegável que a criação da USP insira-se num ambicioso projeto político e cultural não só para São Paulo, com também para toda nação brasileira. Esse projeto fora elaborado por um grupo paulista que, dotado do espírito bandeirantismo e visão política, via na criação da Universidade um instrumento de progresso. (Ibid., p. 25)

Essa ótica, que posiciona a criação da universidade como produto para o progresso em escala local e nacional, apenas desenha um dos diversos movimentos que o território universitário tem capacidade de agregar. O território, sendo mais do que um espaço delimitado com seus conjuntos de prédios, moradias, guaritas, praças, vias, ou melhor, objetos, direciona uma proposta conceitual para o nosso trabalho que provoca nosso entendimento para uma abertura mais ampla da leitura do território do saber universitário: aquela que situa o território como "dado simbólico" (SANTOS, 2012, p. 82) para compreender as relações sociais que se apropriam dos movimentos e são construídas dentro dele. No nosso caso, concebemos o território como elemento ativo para a discussão sobre a população negra.

Caminhamos, assim, para um olhar territorial de universidade, que possui:

\footnotetext{
1 Aqui estamos nos referindo à proposta levantada por Hasbaert (2016), em que o território, com um vínculo mais tradicional, é associado a fundamentos materiais do Estado.
} 
Uma existência material própria, mas sua existência social ocorre por via das relações sociais. Esta é outra forma de apreender o objeto da Geografia; e com o fluir do tempo, cria-se uma configuração territorial que é a cada vez mais o resultado de uma produção histórica.

(SANTOS apud MORAIS, 2013, p. 93)

Nesse sentido, podemos analisar o território da universidade por meio do diálogo com o binômio conceitual de território espaço-tempo, de Rogério Hasbaert (2016), que tem dois sentidos:

i: seu caráter mais absoluto ou relacional: ou seja, no sentido de incorporar ou não a dinâmica temporal (re lativizadora, seja na distinção entre entidades físico-material(como coisa ou objeto) e social-histórica(como relação).ii: Sua historicidade e geograficidade, isto é, se trata de um componente ou condição geral de qualquer sociedade e espaço geográfico ou se essa historicidade está circunscrita a determinado(s) período(s), grupo(s) social(is) e/ou espaço(s) geográficos. (Ibid., p. 41)

O primeiro sentido (i) pensado por Hasbaert leva em consideração a possibilidade de vinculação das características tempo-históricas do território com as produções sóciohistóricas. É nesse âmbito que o entendimento da própria formação da USP está inserido, a ponto de apresentar uma noção da importância das dinâmicas do território e enriquecer uma contextualização histórica das transformações sucessivas que se inscrevem interna e externamente nesse espaço (TURRI apud SAQUET, 2008). De alguma forma, a compreensão do espaço da USP caminha para a relação da história da universidade com os sujeitos que a ocupam. O segundo significado conceitual é, por sua vez, uma perspectiva teórica territorial que dialoga com a historicidade e a geograficidade, com seus determinados grupos sociais e espaços geográficos.

Esses dois significados apresentam pontos importantes a serem discutidos ao longo deste trabalho: historicidade, território e grupos sociais étnicos. São pontos que se relacionam com o debate em busca de compreender o território da Universidade de São Paulo a partir da forma como a população negra ocupa esse espaço, costurando, provocando e fazendo uma reflexão sobre território a partir da individualidade e da coletividade que engloba esse grupo étnico e das múltiplas possibilidades de análise das relações de poder existentes dentro do espaço universitário.

A Universidade de São Paulo, ao ser um importante espaço social para o desenvolvimento territorial da manutenção do saber, permite a formação de recursos humanos, mostrando-se como um decisivo laboratório para a compreensão da produção e 
reprodução do poder e da territorialização e territorialidade ${ }^{2}$, que se manifestam de forma específica em relação a determinados grupos da sociedade. A população negra representa um desses grupos que possui especificidades (OSÓRIO, 2006), fruto de um processo histórico que, como pontua Milton Santos (1987, p. 135), “marcou o território, marcou o espírito e marca até hoje as relações sociais deste país". Dentro da universidade, essa marca específica da população negra pode ser apresentada a partir de espaços de trabalho ou de estudo em que ela tem (ou não) ocupado mais do que o não ne gro ou mesmo estado presente em reproduções ideológicas de poder que fazem com que ela possa ser coagida em determinados espaços da universidade.

O território como fator ${ }^{3}$ (SANTOS, 1987) também produz e reproduz ideologias que tangem as diversas relações sociais existentes na universidade e fora dela. No caso da população negra, vemos que esse grupo tem sido marcado pela clivagem da ideologia racial ${ }^{4}$, que pode condicionar sua trajetória de forma diferenciada em comparação aos sujeitos não negros.

É importante salientar que, quando estamos nos referindo à clivagem criada pela ideologia racial, estamos rediscutindo o conceito de raça, que surge como um discurso biológico e um instrumento de dominação colonial da Europa sobre o resto da população do mundo (QUIJANO, 2005; MOURA, 2014). Com o avanço da ciência no final do século XIX, as teorias raciais adquirem uma nova roupagem, deslocando-se da proposta biológica mantida inicialmente e sendo ressignificadas como um construtor ideológico:

Se mostra, portanto, profunda, perdurável e virtualmente universal a admissão de que a 'raça' é um fenômeno da biologia humana que tem implicações necessárias da história natural da espécie humana e, em consequência, na história das relações de poder entre as pessoas. Nisto se radica, sem dúvida, a excepcional eficácia desde moderno instrumento de dominação social. Não obstante, trata-se de um evidente constructo ideológico que não tem, literalmente nada a ver com a estrutura biológica da espécie humana- e tudo a ver, por outro lado com a história das relações de poder no capitalismo mundial, colonia1/moderno, eurocêntrico. (QUIJANO, 2007, p. 45)

\footnotetext{
${ }^{2}$ Segundo Fernandes (2005), territorialidade e territorialização são dois processos geográficos que estão ligados ao território. A territorialização é resultado da expansão do território, enquanto a territorialidade é o movimento das relações mantenedoras do território e que produzem ações próprias ou apropriadas.

3 Território como motivo, co mo explicação.

${ }^{4}$ Para Johns on (1997, p. 126), as ideologias podem ser consideradas: "um conjunto de CRENÇAS, VALORES e ATITUDES culturais que servem de base e, por isso, justificam até certo ponto e tomam legítimos o status quo ou movimentos para mudá-lo[...].Este fato é especialmente verdadeiro no caso de sistemas opressivos, que requerem justificação detalhada para que continuem a existir. O racismo branco, por exemplo, inclui ideias sobre diferenças raciais que são usadas para convalidar e defender privilégios dos brancos".
} 
A ideia de raça se torna, então, um princípio de classificação que ordena (cliva) e regula o comportamento das relações sociais brasileiras (SANTOS, 2012). A própria história do movimento da população negra no território nacional será caracterizada por mecanismos de controle da mobilidade desse grupo, cujo corpo será marcado e seu território, demarcado (VAINER, 2000), de modo que o conceito de raça se torna um projeto político que se fundava na possibilidade de diferenciação por meio de instrumentos sutis de racismo para construir critérios de distinção da população, como Schwarcz (1993, p. 24) pontua em seu livro $O$ espetáculo das raças:

Em meio a um contexto caracterizado pelo enfraquecimento e final da escravidão e pela realização de um novo projeto político para o país, as teorias raciais se apresentam enquanto modelo teórico viável na justificação do complicado jogo de interesses que se montava. Para além dos problemas mais prementes relativos à substituição da mão-de-obra ou mesmo à conservação de uma hierarquia social bastante rígida, parecia ser preciso manter critérios diferenciados de cidadania.

Nesse livro, a antropóloga discorre a respeito da articulação e da combinação da ideologia racial com o processo político-social que marcou o pensamento do século XIX. Apesar de trazer um relato de um período diferente do qual pretendemos trabalhar aqui, o receio de cometer anacronismos - muito necessário para a seriedade de um trabalho científico - fica fora de questão, já que, no que se refere à ideia de raça, esta parece estar constantemente sendo "renegociada" (SCWARCZ, 1993). Dentro de uma instituição pública como a USP, as trajetórias dos sujeitos negros podem apresentar um indicativo sobre as combinações dessa ideologia racial que, para esses sujeitos pertencentes ao território, cons troem movimentos estereotipados em relação a eles - como é o caso da descriminação e, ao mesmo tempo, criam movimentos de luta e resistência contra essa ideologia presente como é o caso do movimento negro.

Todavia, para o desdobramento de uma proposta que tende a trazer a leitura do território da USP, articulando-o com a população negra que o ocupa, é preciso ser feito um levantamento conceitual extremamente sólido. Hasbaert (2015), em seu trabalho sobre os dilemas e conceitos de espaço-território e contenção territorial, relata, inclusive, a importância de não vincular as categorias a uma mera abstração ou a uma mera representação de uma reflexão sobre o real. Para o autor, os conceitos não são algo "estanque" ou que se pode dividir claramente em um universo, seja ele empírico ou eminentemente teórico. Dessa forma, para a compreensão da geografia da população negra na USP, precisamos ter o entendimento 
dessa construção conceitual sobre o real que envolve esse grupo e que acaba sendo uma manifestação de cruzamentos e uma multiplicidade de influencias teóricas:

Devemos reconhecer que vivemos hoje um entrecruzamento de propostas teóricas, e são muitos, por exemplo, os que contestam a leitura materialista com aquela que responde pelos fundamentos primeiros da organização social. Somos levados, mais uma vez, a buscar superar a dicotomia matéria/ideal, o território envolvendo ao mesmo tempo, a dimensão espacial material das relações sociais e o conjunto de representação sobre o espaço ou o imaginário geográfico que não move como integra ou é parte indissociável destas relações. (Ibid., p. 42)

Essa diversidade de propostas conceituais dá significado para Geografia do Trabalho, enriquecendo a nossa proposta de estudo sobre o território da USP, a qual, atrelada a teorias historiográficas, antropológicas e sociológicas, possibilita o entendimento de um todo que circunscreve o debate das relações raciais no Brasil. A costura que permeia o debate territorial nos faz, portanto, pensar e criticar o movimento que a comunidade negra universitária faz nesse espaço, fundamentando, assim, múltiplos conceitos que permeiam uma dialética de produtor e produto das relações que se materializam dentro da Universidade de São Paulo.

Na Geografia brasileira, autores como Santos (2007), Campos (2005), Cirqueira (2010) , Ratts (1996), Guimarães(2015), Malachias(2006), Vieira(2017), Gomes(2009) têm, em suas diversas abordagens, permitido a aproximação da disc ussão espacial com a leitura das relações raciais no espaço. São trabalhos que, apesar de serem relativamente recentes na Geografia nacional, já apresentam em sua densidade teórica um grande avanço para compreender as desigualdades geográficas que são registradas a partir do critério do corpo negro. Sodré (1982, p. 119-120), por sua vez, já fazia críticas ao pensamento geográfico humano e à sua miopia sobre a análise do conceito racial:

Os principais trabalhos vinculados à geografia humana trazem capítulos acerca da distribuição espacial da raça. No entanto, o pensamento geográfico em curso e a geografia moderna possuem vínculo pouco evidente com as teorias raciais e racistas que ora enfatizam superioridade de uma raça/etnia sobre outra(s), ora desqualificam a variável raça na análise geográfica.

Não cabe aqui fazermos uma discussão sobre o pensamento moderno geográfico, mas é necessário pontuar a importância que Sodré atribui ao debate das ideologias raciais e como este poderia enriquecer conceitualmente os estudos espaciais. Essa perspectiva nos auxilia, no presente trabalho, a compreender possíveis influências que o racismo teria na produção do 
movimento territorial da população negra universitária da USP, criando espaços dentro da instituição onde essa população estaria mais ou menos ocupando e determinando relações e contradições entre os sujeitos a partir da clivagem do racismo. Dessa maneira, com a nosso trabalho, é possível contribuir para alavancar esse debate no âmbito das discussões das desigualdades espaciais que, a partir de um pensamento que rediscute o papel da ideologia racial dentro do território da USP, possibilita leituras das múltiplas ferramentas de poder a que um grupo está sujeito.

Assim, muito além da referência de localização (GOMES, 2008), o conceito de território, a partir da lógica do poder, autoriza nossa discussão a ir mais a fundo no que tange às relações sociais. Analisando a territorialidade como uma dinâmica territorial e entendendo esta como uma manifestação (ação) do poder que influencia ou controla estrategicamente as pessoas no espaço (GOMES, 2008), percebemos que a territorialidade e a territorialização se tornam ferramentas que oferecem um necessário caminho para a construção do pensamento que relaciona a Geografia da população negra com as ideologias raciais que ainda produzem, para esse grupo social, "trajetórias diferenciadas" (SANTOS, 2012, p. 42).

\section{Organizando os caminhos e estruturando o corpo do trabalho}

Para compreender a totalidade das múltiplas relações que a população negra universitária - servidores(as), docentes, estudantes - terá com o território da USP, iremos estruturar nosso trabalho nos três pontos desenvolvidos por Santos $(2000)^{5}$ para pensar como a questão do negro transpassa o Brasil e a escala da academia. Por meio da corporalidade, da individualidade e da cidadania, a pesquisa pretende costurar um caro debate sobre a espacialização e a produção do território a partir da perspectiva da população negra.

Quando objetivamos discutir a geografia do território da Cidade Universitária por meio da corporalidade da comunidade negra, ou seja, do corpo de uma população presente nesse espaço do saber acadêmico, visualizamos nessa proposta uma abertura para o estudo das questões que interligam as especificidades contidas na trajetória histórica da população negra, as ideologias que constroem para o corpo negro, as desigualdades marcadas pelas relações étnico-raciais e a relação dessa população com o território da universidade.

Assim, nesse primeiro momento, o que pretendemos expor é a íntima ligação que o corpo da população negra tem não somente com a universidade, mas também com todo o

\footnotetext{
5 Milton Santos (2000), em um artigo para a Folha de S. Paulo chamado "Ser negro no Brasil", escreve que existem marcas visíveis que caracterizam o negro brasileiro. Segundo o geógrafo, a discussão desse problema poderia partir de três dados de base: a corporeidade, a individualidade e a cidadania.
} 
processo histórico de formação do território nacional (VAINER, 2000). Esse processo, que criou uma vivência, ou melhor, um cotidiano, que supõe o passado como herança (SANTOS, 1996), nos permite aguçar nossa discussão para averiguarmos se esse corpo ainda se mantém marcado com "símbolos sociais" (FERNANDES, 2008, p. 95) que determinam uma padronização em torno da etnia ou da cor e, de alguma forma, causariam uma condição operante para territorialização da corporalidade negra na Universidade de São Paulo. Nesse sentido, o corpo será tomado como uma "realidade que se avulta e se impõe" (SANTOS, 1996, p. 10) para analisarmos as funções que estão predispostas nos diferentes usos do espaço universitário por parte dessa população, de modo que, nesse primeiro momento, aprofundaremos os estudos das características que se referem tanto aos(às) estudantes como aos(às) servidores(as) negros(as) da Universidade de São Paulo.

É importante salientar que, para Milton Santos, a corporalidade é uma dimensão objetiva que envolve a forma com a qual o sujeito se apresenta e se enxerga, a sua virtualidade, educação, riqueza, capacidade, mobilidade, localidade e lugaridade. Acreditamos, além disso, que a corporalidade também possibilita analisar as múltiplas territorialidades e territorializações da população negra dentro da Universidade de São Paulo, permitindo, desse modo, um estudo sobre as possibilidades e dificuldades existentes no processo de ocupação da USP como negro.

Cabe também, aliás, fazer uma observação mais minuciosa no que diz respeito à questão de gênero para o entendimento da totalidade das relações da comunidade negra da USP, pois, no desenvolvimento dessa corporalidade, as barreiras para as mulheres negras (GONZALES, 1982; DAVIS, 1982) marcam o corpo negro feminino e seu trânsito no território (RATTS, 2010), criando uma característica específica para essa corporalidade e entrando em diálogo direto com a questão étnico-racial e de gênero.

Portanto, a corporalidade negra presente na USP ditará o trabalho de forma objetiva. Além do levantamento teórico, que será caracterizado pela compreensão da espacialização desse grupo no território, o debate sobre a corporalidade estará também vinculado ao sentido dos objetos que estão presentes na USP que, de alguma forma, dão significado para o todo. Acreditamos, como Gomes (2008, p. 39), que o território, além da proposta de delimitação, proporciona um estudo sobre "a forma de espacialização dos objetos, ou seja, a maneira como esses objetos estão distribuídos e relacionados no espaço" que permite que esta "seja um dos fundamentos que delimitam e condicionam as dinâmicas sociais que aí tem lugar”. Assim, a partir da criação de um mapa de densidade da população ne gra que ocupa o campus Butantã, 
iremos propor uma descrição teórica e visual sobre as dinâmicas espaciais que tomam em notas as formas como a USP é usada por esse grupo, possibilitando um debate a respeito dos modos e características de apropriação do território e dos objetos existentes na USP por parte da comunidade negra.

O segundo ponto que estrutura o trabalho se refere à individualidade dos sujeitos estudados. Nesse sentido, esse objetivo implica buscar entender a subjetividade através de uma pergunta: o que é ser negro(a) no território da Universidade de São Paulo? Para Santos (1996, p. 10), a subjetividade é:

\begin{abstract}
Aquela que têm a ver com a individualidade que conduzem a considerar os graus diversos de consciência dos homens. Consciência do mundo, consciência do lugar, consciência de si, consciência do outro, consciência de nós. Toda esta forma de consciência tem a ver com a individualidade e lhe constituem gamas diferentes, tendo também que ver com a transindividualidade, isto é, com as relações entre indivíduos, relações que são uma parte das condições de produção da sociedade, isto é, do fenômeno de estar juntos.
\end{abstract}

A pergunta acima se relaciona com a consciência que os sujeitos da pesquisa têm sobre a sua individualidade, que também pode ser entendida como um dado necessár io para a formação da identidade de um grupo (RATTS, 2004) e pode proporcionar para a população negra da USP sentidos, valores, apropriações e produções distintas de acordo com o nível de sua trajetória ou consciência de mundo. A consciência do outro - o não negro - e a sua branquitude(SCHUCMAN, 2014) também são caracterizadas por essa proposta de compreensão da subjetividade, já que as relações sociais entre negro e não negro resultam, no Brasil, em um debate sobre os privilégios existentes dentro do território e que estão além do espaço universitário da USP, pois são intrínsecos à sociedade.

Para a análise dessa segunda etapa foram realizadas entrevistas ${ }^{6}$ semiestruturadas, que constituem "uma técnica alternativa para se coletarem dados não documentados sobre determinado tema" (GERHARDT; SILVEIRA, 2009, p. 72) e, nesse caso, os dados são articulados com os diferentes sujeitos. Desse modo, para proporcionar um verdadeiro entendimento de como essa população se apropria do território, coletamos entrevistas de uma gama de sujeitos e funções - professores(as), estudantes, servidores(as) técnicoadministrativos, etc. - para traçar um caminho que leve à compreensão dessa totalidade territorial.

\footnotetext{
${ }^{6}$ As entrevistas foram conduzidas por um roteiro comum e agendadas de acordo com a disponibilidade do entrevistado, escolhendo o lugar e o horário que melhor se enquadras sem com as suas especificidades.
} 
As entrevistas enriquecem o trabalho com o conhecimento prévio dos sujeitos pesquisados. É de extrema importância que essa etapa avance na discussão sobre o território universitário - mesmo que em uma escala individual -, apresentando a consciência do debate coletivo do negro brasileiro. Como o trabalho irá tratar em especial de um ambiente acadêmico, decidimos utilizar a técnica metodológica snowball, também conhecida como snowballsampling (bola de neve), usada em pesquisas sociais "onde os participantes iniciais de um estudo indicam novos participantes que por sua vez indicam novos participantes e assim sucessivamente, até que seja alcançado o objetivo proposto (o 'ponto de saturação')[...]" (BALDIN \& MUNHOZ, 2011, p. 332).

No caso da comunidade negra, o ponto de saturação é baseado em dois fatores importantes: a amostra percentual referente aos dados oficiais da USP sobre essa população que se reconhece como negra ${ }^{7}$ dentro do campus e as repetições dos conteúdos das entrevistas, que tenderam, no decorrer da "bola de neve", a saturar as informações relevantes à pesquisa. Essa técnica permite a construção de uma espécie de rede na medida em que é solicitada dos primeiros participantes do estudo a indicação de sujeitos que sejam interessantes e possam contribuir com informações para a pesquisa, permitindo, assim, uma articulação potencial e dando uma visibilidade "a atores sociais específicos e relevantes dentro de suas comunidades" (Ibid., p. 333).

A última parte do trabalho envolve a busca pelo entendimento dessa população da USP sob a ótica da cidadania. Compreendemos que, no sistema capitalista, através de um conjunto de relações de dominação e exploração, tem sido construídas hierarquias sociais que organizam trajetórias desiguais dos indivíduos (SANTOS, 2012), ou melhor, "cidadanias mutiladas" (SANTOS, 1996/1997). Nesse momento, o presente trabalho intenta apreender como tem sido marcada a luta pela cidadania para e da população negra dentro da USP, deslocando nosso olhar para o movimento negro universitário, que tem, a partir das políticas afirmativas como as cotas, buscado questionar os lugares da população negra (GONZALES, 1982) determinados pelas relações étnico-raciais brasileiras, fazendo com que esta crie como resposta um espaço de luta e reivindicação por seus direitos dentro do campus. Percebemos que a relação do debate da cidadania com o movimento negro segue também como uma crítica contundente às relações étnico-raciais brasileiras, especificamente à mitologia criada pela política da democracia racial (MUNANGA, 1999).

\footnotetext{
${ }^{7}$ A autodeclaração respeita os critérios utilizados pelo IBGE.
} 
A presente pesquisa procura, portanto, outras interpretações sobre o território da USP a partir das percepções da comunidade negra. Apoiamo-nos no pensamento de Deleuze, lembrado por Hasbaert (2015, p. 94), de que as interpretações "nunca são descomprometidas e neutras, mas também uma forma de implicação/recriação do/com o mundo”. Deseja-se, então, de forma contundente e madura, propor uma (re)visão dessa importante universidade a partir do olhar dos sujeitos que produzem, com suas trajetórias e práticas, uma variedade de interpretações que enriquecem o debate - não só com base em uma materialidade territorial, mas também em uma subjetividade social - em torno da relevância que a USP possui. 


\section{CAPÍTULO 1- O territónio da USP e a territorialidade do corpo negro}

\subsection{Entendendo conceitos: território, territorialização e territorialidade}

A leitura que a categoria de território traz para a discussão geográfica sobre o mundo e suas amplas relações permite que o debate sobre o espaço convirja para uma indagação primordial, feita por Souza (1995, p. 78): "quem domina ou influencia esse espaço e como?" Essa indagação abre caminho para a possibilidade de se discutir de maneira mais aprofundada os modos de utilização e apropriação do território.

Autor importante para o entendimento do território e suas premissas, Rogério Hasbaert (2016) faz um resgate da origem da palavra território. Segundo ele, a palavra território "é diretamente derivada do vocábulo latino terra, e era utilizada pelo sistema jurídico romano dentro do jus[...] como pedaço de terra apropriado, dentro dos limites de uma determinada jurisdição político-administrativa" (Ibid., p. 43). A etimologia do conceito de território revela, portanto, uma relação entre apropriação e domínio, que Hasbaert (2008, p. 21) conceitua como "dupla conotação, material e simbólica", já que a terra, sendo a camada superficial do globo, é operada como elemento material para a manutenção da vida, mas, ao mesmo tempo, também é restrita aos que possuem o "privilégio em usufrui-lo", de modo que "o território se torna uma identidade (positiva)" (Ibid., p. 44).

A compreensão do território faz com que a Geografia, enquanto ciência estuda a forma como os sujeitos, de modo estraté gico, mantêm o espaço. Sack (1986) dialoga com um debate importante sobre esse esforço de entendimento do conceito de território, pois:

Os territórios requerem esforço constante para estabelecê-los e mantê-lo. Eles são resultados de estratégias para afetar, influenciar e controlar pessoas, fenômenos e relações. Circunscrevendo coisas no espaço ou em um mapa, como quando um geógrafo delimita uma área para ilustrar onde o milho cresce ou onde a indústria está concentrada, identificar locais, áreas ou regiões no senso comum, mas não criando propriamente um território. Esta delimitação se torna um território somente quando as suas fronteiras são usadas para afetar o comportamento ou para controlar o acesso. (Ibid., p. 20)

A delimitação construída por uma fronteira é a caracterização clássica do conceito de território. Para Morais (2002), a fronteira é constituída por linhas que delimitam formalmente áreas de soberania, norteando e desenhando, inclusive, as propostas de uma Geografia política tradicional, em que o território será fundamentalmente, como Souza (1995) o concebe, um espaço concreto, com seus atributos naturais e socialmente construídos e ocupado/apropriado 
por um grupo social.

Nessa Geografia política clássica encontramos a amplitude do debate territorial que Hasbaert (2016) define como jurídico-político. No interior dessa discussão, são abordadas, em uma perspectiva materialista, questões que têm um enfoque nas leituras políticas do território, principalmente aquelas que abrangem o Estado.

Um importante autor clássico da Geografia que recorre a essa linguagem política do território, fazendo um trabalho que constrói uma ponte para a relação do povo com seu território, é o alemão Friedrich Ratzel (1990). Para ele, a existência do Estado só se dá por causa de seu território e de suas respectivas fronteiras, sendo fácil convencer-se de que, do mesmo modo como não se pode considerar mesmo o Estado mais simples sem seu território, assim também a sociedade mais simples só pode ser concebida junto com o território que lhe pertence, de maneira que o envolvimento que o Estado tem na função da existência e da manutenção do seu território é primordial para o desenvolvimento político:

O Estado protege o território contra as violações vindas de fora, que podem reduzi-lo. Naqueles países que alcançaram o apogeu do desenvolvimento político, servem este objetivo não só as fronteiras e as disposições para a defesa destas, mas também o tráfico e o desenvolvimento dos recursos do solo, em suma todos os meios que servem para aumentar a potência do Estado, cuja missão é e continua sendo sempre da proteção. (Ibid., p. 76)

Dessa forma, o território, para o geógrafo alemão, se torna elemento de pertença tanto para o Estado - que possui a função de protegê- $\mathrm{lo}^{8}$ - quanto para a sociedade que, profundamente enraizada nesse território, só alcança o desenvolvimento potencial se as suas fronteiras estiverem de fato bem protegidas, permitindo, desse modo, a solidez das propriedades naturais necessárias para o crescimento econômico.

Essa ótica, vigente em uma Geografia política tradicional, que configura um território como um espaço "concreto em si" (SOUZA, 1995, p. 84 ), tendo seus atributos naturais socialmente construídos e apropriados por um grupo social, faz com que essa categoria geográfica se torne um elemento para entender as relações que se referem ao espaço. Porém, é notória, muitas vezes, uma leitura aproximada dessa categoria com a categoria de espaço em discussões que caminham para o debate das relações sociais na Geografia.

Essa aproximação entre as categorias geográficas de espaço e território é entendida por

\footnotetext{
${ }^{8}$ Como foi o caso do conceito de "Espaço vital" (RATZEL, 1990), que nada mais é do que um território estratégico para a manutenção do poder do Estado.
} 
Medeiros (2015, p. 215) como “condição para que o espaço se humanize", já que, para o autor, tanto a categoria de espaço como a categoria de território são correlacionadas pela existência uma da outra. Nessa mesma linha de pensamento, mas representando uma análise processual de desenvolvimento dessas categorias, Raffestin $(2015$, p. 27) afirma que o espaço antecede o território, pois "este é gerado a partir do espaço, constituído o resultado de uma ação conduzida por um ator que realiza um programa em qualquer nível. Apropriando-se concretamente ou abstratamente (por exemplo, atra vés da reprodução) de um espaço, o ator o territorializa".

Outro importante geógrafo para aguçar/criticar os sentidos sobre o envolvimento entre essas duas categorias geográficas é Milton Santos. A partir do conceito de território usado é possível propor uma relação direta do território com o espaço como base do processo histórico e das ações humanas:

Foi por isso que propusemos considerar o espaço geográfico não como sinônimo de território, mas como território usado; e este é tanto o resultado do processo histórico quanto a base material e social das novas ações humanas. Tal ponto de vista permite uma consideração abrangente da totalidade das causas e dos efeitos do processo socioterritorial. (SANTOS, 2000, p.104)

Milton Santos foi um autor que, nesse sentido, estimulou o debate sobre território, pontuando que:

Imutável em seus limites, uma linha traçada de comum acordo ou pela força. Este território não tem forçosamente a mesma extensão através da história. Mas em um dado momento ele representa um dado fixo. Ele se chama espaço logo que encarado segundo a sucessão histórica de situações de ocupação efetiva por um povo - inclusive a situação atual - como resultado da ação de um povo, do trabalho de um povo, resultado do trabalho realizado segundo as regras fundamentadas do modo e produção adotados e que o poder soberano torna em seguida coercitivas. É o uso desse poder que, de resto, determina os tipos de relações entre classes sociais e as formas de ocupação do território. (SANTOS, 2012, p. 233)

Apesar desse envolvimento indissociável entre as duas categorias, será no território que ocorrerá um foco centralizado da "espacialidade das relações de poder" (HASBAERT 2012, p. 101), ou seja:

o território se define mais estritamente a partir de uma abordagem sobre o espaço que prioriza ou coloca seu foco no interior dessa dimensão espacial, na 'dimensão', ou nas problemáticas de caráter político ou que envolvem a 
manifestação/realização das relações de poder em suas múltiplas esferas. (Ibid., p. 103)

Esse poder, que Raffestin (1993, p. 53) compreende como a "multiplicidade das relações de forças que são iminentes ao domínio em que elas se exercem e são constituídas de sua organização", estrutura a forma como se articula o território no âmbito das relações, sendo o meio de instrumentalização do domínio da distribuição e/ou controle dos objetos especializados (GOMES, 2008). Essa característica, que guia diferentes sentidos e significados para território, permite uma análise do espaço de acordo com os objetivos pesquisados, ou, nas palavras de Milton Santos (2012, p. 233), será determinante para "entender os tipos de classes sociais e as formas como se usa o território".

É importante salientar que o território sempre foi posto como instrumento de manutenção, conquista e exercício do poder (SOUZA, 1995). Na literatura não é difícil encontrar exemplo de batalhas que foram vencidas simplesmente pelo entendimento e pelo domínio territorial. Essa leitura clássica e materialista, em que a imagem territorial acaba sucumbindo, é essencial, mas não suficiente para a compreensão total das diversas possibilidades que o debate pode acarretar na Geografia. A partir do poder, temos uma amplitude de abordagem do que "uma pessoa ou um grupo alcança impor sobre outro indivíduo", de modo que "isso significa que o título ou os títulos desse domínio logram êxito na ação de influenciar ou controlar outra pessoa desde uma estratégia verdadeiramente espacial" (GOMES, 2008 ,p. 38).

A discussão a respeito do poder, em que o território acaba sendo pautado, faz com que essa categoria seja palco para uma abordagem que não se limita apenas ao lado material e funcional que a Geografia política tradicional trazia com sua face concreta e fechada, baseada em fronteiras e convergente com o Estado. O olhar sobre as relações de poder permite um envolvimento com o controle territorial, que depende do tipo (funcional ou simbólico) dos sujeitos que promovem o território, fazendo com que a intencionalidade não seja centralizada apenas na figura do Estado, pois tem uma intencionalidade mais diversa (HASBAERT, 2016). Essa diversidade territorial do poder, que nada mais é do que uma multiplicidade "das relações de força que são iminentes ao domínio em que elas se exercem e são constituídas" (RAFFESTIN, 1993, p. 52), faz do território um espaço rico em possibilidades de estudo, entendendo o poder, nesse contexto, tanto no seu sentido concreto de dominação, quanto no sentido mais simbólico de apropriação.

Apesar de suas especificidades, nas sociedades indígenas ou quilombolas - que são 
casos expressivos dessa multiplicidade de relações -, a análise do poder se torna importante para a compreensão do uso e da apropriação dos territórios, em que a ideia de poder exige, nesses casos, um entrelaçamento das percepções simbólica e material do território. Desse modo,

Facilmente podemos afirmar que ela constrói o seu território como áreas controladas para usufruto de seus recursos, especialmente os recursos naturais (algo bastante genérico e, portanto, variável entre os diferentes grupos). Mas os referentes espaciais, aí, também fazem parte da vida dos índios como elementos indissociáve is na criação e recriação de mitos e símbolos, podendo mesmo ser responsável pela própria definição do grupo enquanto tal. (HASBAERT, 2016, p. 69)

É notório que o autor acima está se fundamentando em uma perspectiva territorial que ele assinala como sendo idealista, ou melhor, um território que reforça "sua dimensão enquanto representação do simbólico" (Ibid., p. 71). Nesse caso, a dinâmica de comunicação que o espaço tem com os sujeitos que o ocupam liga-se fortemente à sua existência, em que esta pode se confundir com o discurso levantado pela proposta clássica de território, embora os valores sejam distintos, principalmente quando se baseia na ótica local dos sujeitos. Sobre isso, Hasbaert (2016), ao discutir o conceito de território, vale-se da linha de pensamento de dois geó grafos franceses, Bonnemaison e Cambrèzy (1996), segundo os quais:

O território reforça sua dimensão enquanto representação local. A abordagem utilitarista de território não dá conta dos principa is conflitos do mundo contemporâneo. Por isso, 'o território é primeiro um valor', pois é 'a existência humana de estabelecer uma relação forte, ou uma relação espiritual com seu espaço de vida, claramente estabelecida. (Ibid., p. 71)

Essa multiplicidade de sentidos que a discussão territorial evoca é difundida na primazia das relações sociais que serão costuradas sob a ótica do poder. Para Rasffettin (1993, p. 53), essa ideia das relações é o "ponto de surgimento do poder" e fundamenta sua variabilidade.

Dessa maneira, as diversas relações que dão luz para o território autorizam essa categoria geográfica a oferecer um leque de análises que só faz sentido aos sujeitos quando relacionamos estes ao contexto temporal em que estão inseridos. Em outras palavras, o território se define antes de tudo "com referência às relações sociais [...] e ao contexto histórico" dos indivíduos (HASBAERT, 2015, p. 78).

Quando Saquet (2015), ao complementar as ideias de Quaini (1974; 1974a), 
Dismattéis (1985) e Turri (2002), discute a abordagem temporal na Geografia a partir do aspecto territorial, o território é visto como produto social constituído na história, na economia, na política e na cultura e fruto de uma articulação maior. Sendo resultado das relações espaço-tempo, o conceito de tempo histórico tem uma centralidade para o território e, nesse sentido, ao ser apresentado como elemento histórico, se afasta da proposta de um espaço cristalizado e se torna objeto de mudança, com dinâmicas que variam de acordo com as relações que nele ocorrem.

As relações sociais, por não serem fixas, são produtoras de movimentos territoriais que Fernandes (2005, p. 32) pontua como:

[...] desiguais, contraditórias e completivas. Este movimento nada mais é que ações, movimentos e expressões, materiais e imateriais dentro do território multidimensional, que cria/descria, expande/comprime o território. Tal fluxo do território será conhecido como territorialização e permite interpretar as relações que estão dialogando - ou não - dentro do território.

À luz disso, enquanto a territorialização é resultado da expansão do território, sendo contínua ou ininterrupta, a territorialidade seria a manifestação dos movimentos das relações mantenedoras dos territórios que produzem e reproduzem ações próprias ou apropriadas (FERNANDES, 2005).

Muito além do conceito político, a territorialidade também é um conceito fundamental para compreendermos a forma como os diversos sujeitos produzem e reproduzem o espaço, pois esse aspecto está "intimamente ligado ao modo como as pessoas utilizam a terra, como elas próprias se organizam no espaço e como elas dão significado ao lugar" (SACK, 1986, p. 6776), de maneira que

\footnotetext{
A territorialidade como um componente do poder não é apenas um meio para criar e manter a ordem, mas é uma estratégia para criar e manter grande parte do contexto geográfico através do qual nós experimentamos o mundo e o dotamos de significado. (HASBAERT, 1989 apud HASBAERT, 2005, p. 6776)
}

Sendo uma estratégia, a territorialidade se transforma em um instrumento para a leitura das ações existentes no território, atribuindo-lhes significados diferentes de acordo com a forma como essa prática territorial se manifesta, inclusive no modo de controle das pessoas. A respeito disso, Sack (1986, p. 6) afirma que: 
A Territorialidade para os humanos é uma estratégia geográfica poderosa para controlar pessoas e coisas através de um controle de área. Os territórios políticos e a propriedade privada da terra podem ser as suas formas mais familiares, mas a Territorialidade ocorre em vários graus e em inúmeros contextos sociais. Ela é usada nas relações do dia-a-dia e nas organizações complexas. A Territorialidade é uma expressão geográfica primária do poder social. Ela é um meio pelo qual o espaço e o tempo estão interrelacionados. A mudança de funções da Territorialidade nos ajuda a entender as relações históricas entre a sociedade, o espaço e o tempo.

Esse controle mencionado pelo autor é "aquilo que faz qualquer território, um território, isto é, de acordo com o que se disse há pouco, relações de poder espacialmente delimitadas e operando sobre um substrato de referência" (SOUZA,1995, p. 99). Assim, independentemente das diversas perspectivas sob as quais um território pode ser concebido das materialistas até as mais simbólicas -, esse controle busca costurar os interesses dos sujeitos que produzem o espaço para a delimitação e organização do poder existente nele:

A Territorialidade, então, forma um cenário para as relações espaciais humanas e as concepções do espaço. A Territorialidade aponta para o fato de que as relações espaciais humanas não são neutras. As pessoas simplesmente não interagem no espaço e se movem através do espaço como bolas de bilhar. Ao invés disso, a interação humana, o movimento e o contato são também questões de transmissão de energia e informação, para afetar, influenciar e controlar as ideias e ações de outros e seus acessos às fontes. As relações espaciais humanas são resultados da influência e do poder. A Territorialidade é a forma espacial primária do poder. (SACK, 1986, p. 30)

Esse poder já mencionado, atrelado às relações espaciais que produzem e dão ao território sua multiplicidade, será a característica de controle que revela a importância e a finalidade de constituição de um território como fundamentalmente "um espaço definido e delimitado por e a partir de relações de poder" (SOUZA, 1995, p. 78). Porém, o mesmo autor lembra que qualquer poder precisa de uma base ou de um referencial para ser compreendido por exemplo, o contexto histórico do território e dos sujeitos que fazem parte desse espaço e que representam significativamente a base estrutural necessária para o entendimento da totalidade. Assim, iremos nos prender a esses dois apontamentos para encorpar ainda mais o debate sobre o território da USP e a própria construção histórica do negro brasileiro como uma problemática territorial. 


\subsection{Raça e racismo nas fronteiras do corpo negro brasileiro}

O contexto histórico da população negra brasileira no período escravocrata envolve, sobretudo, uma discussão territorial entrelaçada às questões específicas que se referem à população negra. A migração forçada, que criou um movimento do continente africano para as Américas de histórias e geografias de diversas etnias negras, teve consequências diaspóricas profundas. Mesmo no período de ensaio para a "libertação" negra, entre 1850 e 1888, a geografia territorial se fez presente com inúmeras políticas territoriais e institucionais que, "do escravo para o cidadão" (FERNANDES, 2008, p. 63), permitiram o controle da mobilidade dessa população (VAINER, 1987) ao longo do território nacional.

Assim, em 1850, ano do fim do tráfico externo de escravizados, é instituída a Lei de Terras, que versava a respeito das terras devolutas do Império: “acerca das que são possuídas por título de sesmaria sem preenchimento das condições legais, bem como por simples título de posse mansa e pacífica; e determina que, medidas e demarcadas as primeiras, sejam elas cedidas a título oneroso" ", ou seja, só poderiam ter as terras - e por que não territórios - quem tivesse dinheiro o bastante para comprá-las, o que era bastante raro para a população negra. Outro exemplo de restrição à mobilidade territorial ocorreu também em 1871, com a Lei do Ventre Livre, por meio da qual foi determinado que todo negro que nascesse depois da promulgação da lei seria livre, mas sob a condição de ficar até os 21 anos com o senhor na fazenda.

Mesmo com o a Lei Áurea em 1888, que decretou formalmente o fim da escravidão, esse conjunto de causas complexas, em diálogo com o sistema capitalista e as práticas e teorias raciais, fez com que o negro, apesar de não ser mais escravizado, ficasse condenado ao estigma da colonização, com estereótipos que relacionavam sua cor a uma conotação negativa. Assim, o negro, que antes estava com o corpo marcado, agora teria seu território demarcado (VAINER, 1987). Nessas condições históricas, "aqueles que haviam durante outro século, marcado o corpo do negro no exercício privado, da condição de proletariado, agora demarcam seu território no exercício político da condição de classe dominante" (Ibid., p. 68). Assim:

Apesar dos ideais humanitários que inspiravam as ações dos agitadores abolicionistas, a lei que promulgou a abolição dos cativos consagrou uma autêntica espoliação dos escravos pelos senhores. Ao sereno foi concedida uma libertação teórica sem qualquer garantia de segurança econômica ou

\footnotetext{
${ }^{9}$ Disponível em: <http://www.planalto.gov.br/ccivil_03/Leis/L0601-1850.html〉. Acesso em 10 ago. 2019.
} 
assistência compulsória, aos senhores e o Estado não foi atribuída nenhuma obrigação com referência às pessoas dos libertos, abandonados à própria sorte daí em diante. (FERNANDES, 2008, p. 66)

Quando Florestan Fernandes pontua sobre uma dita "libertação teórica", ele está se embasando nas políticas de branqueamento, quando o Estado moderno brasileiro normatiza o território em "busca da nação civilizada" (Ibid., p. 71). Desse modo, o branqueamento da população, causado pela vinda dos imigrantes europeus, foi uma política territorial para reconstruir uma nação a partir de uma base europeia, sobretudo com o objetivo de apagar da história e geografia brasileiras a participação negra. Alguns dados mostram que o fenômeno do branqueamento era tratado como um processo irreversível, tendo, inclusive, a explícita ambição de extinção - leia-se genocídio - da população negra nos censos nacionais, a exemplo do que aconteceu em São Paulo, que recebeu a maior leva de imigrantes.

As políticas de branqueamento demonstram que as relações que se referem ao território e à abolição não significaram o fim das práticas sociais e espaciais pautadas pela raça. Nesse sentido, embora o fim da escravidão tenha sido um marco simbólico fundamental na história, principalmente na estrutura funcional do trabalho, o mosaico colonial que regia as relações cotidianas não cessou com o passar do século; ao contrário, permanece como discurso teórico do pós-colonialismo, a partir de uma relação de colonialidade do saber e do poder.

Milton Santos não traça um debate profundo a respeito disso, mas era, como ele mesmo salientava, um homem negro que não pode ser "indiferente à questão" (SANTOS, 2000, p. 1), trazendo, então, uma leitura muito crítica desse período histórico pós-libertação. Segundo ele, "os interesses cristalizados produzem convicções escravocratas arraigadas e mantêm estereótipos que ultrapassam os limites do simbólico e têm incidência sobre os demais aspectos das relações sociais" (Ibid., p. 1). Dessa forma, apesar do fim da escravidão, ainda existiam políticas cristalizadas que se baseavam no critério racial para limitar os direitos da população negra ao território nacional.

Se, de um lado, o avanço da ciência genética reivindicou o fim da racialização humana; de outro, o processo de hierarquização conformou uma relação perversa e estagnada entre o biológico - cor da pele e traços fenotípicos - e o psicológico, moral, intelectual e cultural (MUNANGA, 2003), que direta ou indiretamente marca o cotidiano do homem negro e da mulher negra recém-libertos. Desse modo, a produção e a reprodução das relações sociais são regulamentadas por uma clivagem e uma hierarquias de indivíduos ou grupos a partir de 
seu pertencimento racial. Ora, como o historiador Clovis Moura (2014) pontua, em um país onde se teve mais de 400 anos de escravidão, não há como descrever as desigualdades sociais e territoriais sem falar sobre as especificidades que estão presentes na trajetória histórica da população negra.

A hierarquia racial no Brasil é engendrada de forma complexa, articulando inúmeros processos, inscritos inclusive no cotidiano dos sujeitos, sejam eles brancos ou negros, de maneira que o mecanismo social ligado ao racismo organiza esses indivíduos em "trajetórias desiguais" (SANTOS, 2012, p. 42), mesmo que ambos estejam no mesmo contexto econômico. Para o professor Renato Emerson dos Santos (2012), a compreensão dessas combinações ou superposições de hierarquias define "múltiplos eixos de subalternização e discriminação de indivíduos e grupos" (Ibid., p. 42), em que nesse sistema de classificação racial os espaços são dimensionados em momentos de horizontalidade e verticalidade ${ }^{10}$ que, de forma combinatória, trariam para os indivíduos a sensação de democracia:

Essa organização espacial-temporal das relações sociais delineia que nos momentos e lugares em que se define o acesso às riquezas que a sociedade produz (acesso à educação, emprego, saúde, conhecimento e seus instrumentos de produção, posição de poder, etc.) as diferenças raciais são mobilizadas nas formas verticalizadas e hierarquizadas, assim produzindo e reproduzindo inequivocamente as desigualdades raciais. (Ibid., p. 44)

A hierarquização dos territórios, causada principalmente por esse conflito de poder que reproduz os grupos hegemonizados, não negros, construiu fronteiras simbólicas que criaram dificuldades para a população negra. Vemos, no debate sobre negros inseridos na universidade, inúmeras especificidades que tendem a territorializá-los como sem espaços distintos em relação aos não negros. Nesse sentido, o território como processo que reflete um contexto histórico, um espaço não inocente e que passou por uma aceleração desigual (SANTOS, 2005), permite compreender de uma forma minuciosa as relações étnico-raciais no interior de uma falsa democracia racial.

Sobre essa democracia, é importante ressaltar que a obra de Gilberto Freyre (2005) contribui para a ideia de que não existe racismo no Brasil, nem mesmo discriminação contra os negros brasileiros, legitimando o pressuposto de que vivemos em um "paraíso racial" que oferece oportunidades iguais a negros e brancos, ou seja, uma verdadeira "democracia racial"

\footnotetext{
${ }^{10}$ Sansone (1996 apud SANTOS, 2012) utiliza de forma semelhante esse critério para diferentes hierarquias, classificando as hierarquias como áreas duras ou moles. As áreas duras seriam os lugares(espaços) em que as dimensões raciais são relevantes; já as áreas moles são espaços onde o negro não encontra dificuldades por causa do seu pertencimento racial.
} 
(CARDOSO, 2002, p. 94). Nessa democracia, a miscigenação seria a variável vital para a criação de um povo sem barreiras, sem preconceito e com uma diversidade cultural, movimento que, de acordo com Kabengele Munanga (1999, p. 80):

Baseado na dupla mestiçagem biológica e cultural entre as três raças, tem uma penetração muito profunda na sociedade brasileira, exalta a ideia de convivência harmoniosa entre os indivíduos de todas as camadas sociais e grupos étnicos, permitindo a elite dominante dissimular as desigualdades e impedindo os membros das comunidades não brancas de terem consciência dos sutis mecanismos de exclusão das quais são vítimas na sociedade.

A territorialidade, movimento dinâmico do espaço, tende a dialogar com esse mecanismo observado por Kabengele Munanga partir das múltiplas características que envolvem o negro na sociedade e fazem com que a comunidade negra ocupe ou não determinados espaços.

É fundamental observar que a ideia de raça foi um instrumento social construído entre os séculos XV e XVI com o intuito de estabelecer a dominação colonial e a diferenciação das "novas identidades sociais e geoculturais de mundos" (QUIJANO, 2007, p. 41) a partir do modelo eurocêntrico. No século XX, por sua vez, o racismo foi trabalhado como uma teoria científica para o projeto do nacional-socialismo, o nazismo, em que derrota deste em 1945 foi fundamental para a deslegitimação do racismo "pelo menos como ideologia formal e explícita, para grande parte da população mundial" (Ibid., p. 41) - o que não significou que as práticas sociais deixassem de ser pautadas pela raça -, influenciando, no Brasil, a consolidação do mito da democracia racial, em que "mesmo aqueles que não são vítimas do racismo (ao menos, diretamente) admitem de bom grado que as relações entre as 'raças' são democráticas, ou mesmo, que são exatamente iguais" (Ibid., p. 41):

Se mostra, portanto, profunda, perdurável e virtualmente universal a admissão de que a 'raça' é um fenômeno da biologia humana que tem implicações necessárias para história natural da espécie e, em consequência, na história das relações de poder entre as pessoas. Nisto se radica, sem dúvida, a excepcional eficácia deste moderno instrumento de dominação social. Não obstante, trata-se de um evidente constructo ideológico que não tem, literalmente, nada a ver com nada na estrutura biológica da espécie - e tudo a ver, por outro lado - com a história das relações de poder no capitalismo mundial, colonia1/moderno, eurocêntrico. (Ibid., p. 45)

Nesse caso, "a raça é um princípio ordenador das relações sociais que opera decisivamente na produção de desigualdade" (SANTOS, 2010, p. 31) e fica evidente no 
espaço universitário, onde o negro expande seu território em lugares onde ele não tem o acesso à riqueza produzida pela sociedade:

Uma sociedade que constitui suas relações por meio do racismo, [...] tem em sua geografia lugares e espaços com as marcas dessa distinção social, no caso brasileiro, a população negra é francamente majoritária nos presíd ios e absolutamente minoritária nas universidades [...]. Essa diferente configuração espacial se constitui em espaço de conformação da subjetividade de cada qual. (SANTOS, 2007, p. 29)

Quando se analisa a presença de negros dentro da universidade, percebe-se, por exemplo, que esses sujeitos estão, sim, espacialmente inseridos, mas são territorializados por uma lógica perversa das relações raciais em nosso país, ou, nas palavras de Carlos Bernardo Vainer (2000, p. 68), o negro possuiu ao longo de sua trajetória o "território demarcado".

No trabalho realizado por Braga (2014) foi retratado como servidores negros estavam espacialmente ocupando os espaços da Universidade Federal de Viçosa (UFV), em Minas Gerais, de forma distinta dos não negros, de maneira que o debate levantado sobre o território da UFV levou à análise das relações que eram produzidas e reproduzidas dentro do território do saber que é a universidade. A partir de levantamentos de dados e das descrições feitas pelos próprios servidores negros, constatou-se que o movimento e a territorialidade desses sujeitos dentro do campus se expressavam de modo diferente dos não negros. Essa territorialidade representou a materialização do racismo institucional e a forma transformadora como este condicionou diferentes trajetórias dentro do ambiente de trabalho. Assim, foi possível constatar que:

A territorialidade apresenta-se como uma estratégia para compreensão do
controle das hierarquias espaciais que se mantém nas múltiplas relações de
poder. Assim, muito além de um processo de entendimento de sujeitos e suas
individualidades, grafar um debate sobre o território/territorialidade, é
emergir em uma narrativa de distinções entre os sujeitos que efetivamente
exercem o poder e aqueles que de fato o controlam e têm o domínio do
espaço. Esse domínio, quando se trata do contexto dos sujeitos de pele negra,
passeia em um translado que se apropria do campo político, econômico e
cultural dos servidores. (Ibid., p. 62)

A compreensão das dinâmicas que se referem à população negra envolve uma denúncia embasada nos "grupos socialmente excluídos e/ou profundamente segregados e, como tal, de fato impossibilitados de construir efetivo controle sobre seus territórios, seja no sentido de dominação político-econômico, seja no sentido de apropriação simbólica-cultural" (HASBAERT, 2004, p. 37). O difícil controle dentro do território ou a impossibilidade de se 
territorializar ou se apropriar de outros espaços é fruto do contexto histórico da formação da nação brasileira que, sustentada em uma falsa democracia racial, criou momentos, como relata Santos(2012), de horizontalidade, ou seja, de integração e igualdade entre brancos e negros, e momentos de verticalidade, isto é, de hierarquias que transformam diferenças em desvantagens que, mesmo contraditórias, coexistem socialmente.

Conforme apontado por Hasbaert (2004, p. 78), "o território de qualquer forma, define-se antes de tudo com referência às relações sociais (ou culturais, em sentido amplo) e ao contexto histórico em que está inserido”. Assim, em uma perspectiva integradora - que não segrega o espaço natural nem o político, econômico ou natural - com as diferentes relações, incluindo a racial, o conceito de território reorienta os estudos espaciais para diferentes leituras, possibilitando que se tenha um entendimento da complexa organização dos sujeitos negros em seus espaços ocupados.

Entendemos, desse modo, que o estudo sobre o território da USP representa não apenas um estudo crítico, desde o pensamento geográfico, do corpo-território, mas também levanta um questionamento sobre como o racismo, enquanto ideologia, forma, transforma e conduz a história e a geografia no território brasileiro, devolvendo para a população negra fronteiras simbólicas que condicionam sua trajetória.

\subsection{Limites distintos: reflexões sobre o negro na cidade de São Paulo}

São Paulo, capital paulista onde a USP está localizada, possui uma gênese peculiar em relação ao contexto de colonização portuguesa no Brasil (FERNANDES, 2008). Essa diferença leva a uma historiografia da presença negra na São Paulo que se difere de outras cidades que já contavam com uma numerosa população negra desde o período colonial. No caso de São Paulo, a população negra só seria marcante a partir do ciclo da mineração. ${ }^{11}$

Outro fator histórico que impacta na geografia negra dessa população é a expansão da economia exploratória de açúcar e café no período da Independência e no processo de constituição do Estado nacional. Esse crescimento permite uma nova relação entre o mercado internacional e o território paulista que, com a intensificação do capital comercial, transfiguraria a imagem dos senhores rurais em uma verdadeira aristocracia agrária paulista.

\footnotetext{
11 "Não obstante, o negro já tinha um nicho na economia paulista ocupando-se em trabalho relacionados com a lavoura e com a obtenção de ouro por lavagem. Assim, quando se intensificavam as bandeiras de capturas de índios, no fím do século XVI e no começo do século XVI, ele se incorpora ocasionalmente à organização; e, quando se constituem as expedições de maior vulto, ele passa a fazer parte da sua estrutura (...) Mas, com a descoberta das minas de ouro, manifestam crescente interesse e empenho na aquisição de escravos africanos, de modo que é pelos fins do século XVII que avulta a importância do negro" (FERNANDES, 2007, p. 155).
} 
No período de destituição do sistema escravocrata, essa mesma aristocracia agrária mira na cidade de São Paulo como uma válvula de escape para os novos investimentos do capital acumulado, construindo na embrionária cidade palacetes e indústrias (SANTOS, 2017). Essa movimentação arquitetônica e industrial não significou apenas uma mudança dos objetos que ocupavam a paisagem da cidade, mas também um deslocamento populacional de antigos senhores de engenhos e de seus investimentos para São Paulo, o que acarretou a "vinda de milhares de negros libertos originários das fazendas de cana-de-açúcar e café espalhadas pelo interior do Estado", que "viam concretizar a sua tão gloriosa liberdade na embrionária metrópole paulista" (Ibid.,p. 24).

Esse processo de transição de regime será, em todo o território, atrelado a difere ntes tipos de contradições; entretanto, em terras paulistas, o rompimento da estrutura escravocrata será muito mais dura e desumana (FERNANDES, 2008), principalmente por terem na sua frente a figura de outro sujeito social: o imigrante europeu.

Os negros e mulatos 'livres', especialmente, encontravam certas oportunidades econômicas, sociais e intelectuais apenas quando a estrutura do sistema escravista funcionou em condições de relativo equilíbrio. Logo que este se rompeu e o polo de equilíbrio deslocou-se para o desenvolvimento gradual do trabalho livre (...) os negros e mulatos 'livres' tiveram pela frente o imigrante, melhor qualificado, mais cotado e sempre preferido. (FERNANDES, 2008, p. 171)

A entrada de imigrantes brancos europeus no Brasil, sobretudo em São Paulo, foi construída com roupagem de progresso. O entendimento de que esses sujeitos chegariam ao território paulista e seriam mais "qualificados" para o trabalho se difundiu no ideário paulista desse período. Porém, além de um projeto econômico do Estado, a apropriação do território paulista pela presença do corpo branco e europeu, principalmente italiano, era também um projeto de branqueamento da população:

A imigração europeia obedece a uma extrema racionalização da elite brasileira, obedecendo a tendência mundial-industrial sobre a necessidade de efetivar no país, especialmente em São Paulo, o marco concorrencial do trabalho livre. Foi um projeto assumido e financiado pe lo Estado brasileiro [...] Tal projeto obedecia a um caráter não só econômico, mas também racial, que instituiu enquanto caráter subjetivo, forma de consciência que vai guiar a concorrência no mercado de trabalho em São Paulo, e vai se enraizar, novamente, enquanto naturalização. (SANTOS, 2017, p. 25)

Como Santos (2017) pontua, esse projeto foi construído para uma ótica de cidade que investia na chegada dos imigrantes europeus para criar, em um primeiro plano, a concorrência 
de mercado entre os variados grupos que ocupavam a cidade. Porém, em um segundo plano, esse projeto revelava que, na prática, existia uma concentração das oportunidades e do prestígio social nas mãos desses imigrantes europeus, que ficaram nas posições mais vantajosas (FERNANDES,2008) se comparados com a população negra, tendo uma “orientação predominantemente racista” (NASCIMENTO, 2016, p. 85).

A territorialização da mão-de-obra branca em São Paulo instituiu um processo de branqueamento que articulou o espaço do trabalho com todo um aparato das relações subjetivas na cidade e em sua população. O branqueamento foi operado principalmente com normas e projetos de leis que tinham como objetivo diluir ou apagar qualquer tipo de geografia que rememorava a presença negra no espaço urbano. São condutas criadas pelo Estado que construíram fronteiras a partir de ideias como a da vadiagem, em que modos racistas de dominação produziam uma imagem negativa sobre a população negra e interferiam diretamente na escolha de quem deveria ou não ter qualidade para assumir um posto de trabalho (SANTOS, 2017). Todavia, ser vadio, não estar na condição de trabalho, não era, para essa população negra, uma escolha, pois dizia respeito a um estado de violência sofrido pelo corpo no pós- abolição e que o posicionou em um quadro desolado de um "período de desorganização social, de apatia e de desmoralização coletiva” (FERNANDES, 2007, p. 171). Dessa maneira, o Estado paulista reduzia toda a especificidade negra ao considerar esses sujeitos como preguiçosos, indolentes e vadios (SANTOS, 2017), tendo como principal objetivo, então, torná-los um problema a ser resolvido na cidade. E qual problema era esse? Segundo Abdias Nascimento (2016, p. 81), esse problema:

Não foi, como devia ser, identificar e implementar a providencia econômica capaz de assegurar a esta nova parcela do povo brasileiro sua própria subsistência. Nem foi o aspecto cerne do "problema", isto é, de que maneira o negro, cidadão recém-proclamado, participaria nos negócios da nação que ele fundara com seu trabalho. E muito menos significava, o 'problema' posto para a elite dominante, a procurar instrumentos válidos e capazes de integrar e promover a colaboração criativa na construção da cultura nacional desse grupo humano recém incorporado à sua cidadania. Autoridades governamentais e a sociedade dominante se mostraram perfeitamente satisfeitas com o ato de condenar os africanos 'livres', e seus descendentes, a um novo estado econômico, político, social e cultural de escravidão em liberdade. Nutrido no ventre do racismo, o 'problema' só podia ser, como de fato era, cruamente racial: como salvar a raça branca da ameaça do sangue negro, considerado de forma explícita ou implícita como 'inferior". 
Assim, essa 'escravidão em liberdade', nutrida pelo racismo, incide no cotidiano desses homens e mulheres negras no pós-abolição no território da cidade de São Paulo. Além disso, a articulação das autoridades governamentais e da elite branca com suas normas sociais de controle e/ou neutralização do corpo negro na cidade (SANTOS, 2017) resultou também em planos de reforma que tinham como objetivo não só "salvar a raça branca da ameaça do sangue negro" (NASCIMENTO, 2016, p. 85), como também apagar toda uma memória arquitetônica negra, presente na geografia da cidade. Com o critério de destruição ou de deslocamento de toda uma arquitetura que remontava a elementos de um Brasil Império escravista para uma São Paulo republicana, industrial e com portes de uma cidade europeia leia-se moderna -, foram introduzidas, nessa explícita construção do 'problema', diversas transformações nas estruturas de vias da cidade que acarretaram uma violência material e simbólica contra a população negra, que viu todo e qualquer tipo de espaço de territorialidade negra ser afetado com os projetos de modernização da cidade de São Paulo.

A pesquisadora Amanda de Lima Moraes (2017), em seu trabalho intitulado "Memória da população negra na cidade de São Paulo: Igreja de Nossa Senhora do Rosário dos Homens Pretos", relata como esse projeto violento e racista de branqueamento da cidade está atrelado ao apagamento de toda uma memória negra no território de São Paulo. Nesse sentido, ela ressalta a função ativa dos decretos e normas urbanas para a criação de uma cidade moderna com características estruturais europeias - leia-se branca. O caso da Igreja de Nossa Senhora do Rosário dos Homens Pretos, localizada no centro da cidade e construída por negros e pela Irmandade do Rosário, é um exemplo, para Moraes (2017), do fatídico branqueamento de São Paulo. A igreja era onde a sociabilidade negra existia, ou como pesquisadora descreve, "local onde a população negra podia frequentar para fazer suas orações, festas de devoção aos santos" (Ibid., p. 9); porém, esse espaço de encontro negro, por não se encaixar no perfil urbano europeu, será diretamente afetado e deslocado para as margens de um centro que surgia, em que o

O apagamento deste suporte material, a igreja, além de ser uma tentativa de remover as manifestações ali realizadas, se coloca como uma tentativa de apagar da memória urbana, a presença destes sujeitos contra hegemônicos visto o contexto de uma cidade que de inúmeras maneiras tentou afastá-los das áreas centrais. (Ibid., p. 39)

Esse afastamento das áreas centrais representou na esfera das manifestações culturais da população negra mais uma forma de controle da circulação desse corpo/memória pelo 
território da cidade de São Paulo, sendo uma das tipologias da violência sobre o corpo negro paulista que se materializava por meio de normas e padrões que contribuíam com a lógica de branqueamento da metrópole. Esta, em seu processo de urbanização, parte para ações que, de tão violentas, podem ora flexibilizar, como no caso da Igreja do Rosário dos Homens Pretos que, apesar de demolida, foi reconstruída em outro espaço, ora, endurecer, a ponto de culminar não só no controle de toda uma simbologia material negra da cidade, mas também na dominação e apagamento de todo um corpo negro. Santos $(2017$, p. 40) afirma que a dominação e o controle se dão

dentro de um modo de produção em colapso, que não mais absorve essa força de trabalho, e que teme pelo descontrole social se tais sujeitos permanecerem soltos e vivos. Impõem-se, assim, à população negra, principalmente aos homens negros jovens, uma morte social, que tem como fim a neutralização violenta desses indivíduos, enquanto regulação produtiva da população que habita o território urbano.

Essa neutralização violenta dialoga novamente com as normas sociais que classificam os sujeitos negros como perigosos e vadios no pós-abolição, classificação que desenha um estereótipo de pessoas perigosas, desenvolvendo, no caso da violência na cidade, um perfil padrão para os sujeitos com altos índices de periculosidade e que segue um termômetro crescente de acordo com a melanina dos indivíduos envolvidos.

O temor do descontrole da população subalternizada não se dilui com o tempo; apenas se remodela, criando, assim, novos métodos, mas com o mesmo objetivo: reduzir a circulação desses corpos negros no território. Santos (2017), em sua pesquisa sobre o racismo e o sistema prisional no Brasil contemporâneo, parte de alguns dados para discorrer sobre esse importante debate, revelando em sua escrita o enorme esforço institucional de aplicação dessa norma social (racializada) presente no imaginário da segurança pública brasileira contemporânea. Segundo o pesquisador:

Ao observar que existe um certo perfil recorrente entre as pessoas encarceradas e assassinadas, podemos notar que a lógica de segurança pública brasileira, ao invés de caminhar para a melhora da condição da vida, segurança e longevidade dessa população, a reduz a uma realidade classista, racista e genocida sob a forma do seletivo encarceramento em massa e do extermínio dos 'marginalizados'. (Ibid., p. 13)

Essa lógica de segurança pública se mantém em São Paulo. Atrelada às gêneses da cidade, o branqueamento da população e da estrutura urbana é sinalizada a partir de um discurso moderno e higienista (SANTOS, 2017) que faz com que a paisagem do território 
paulista seja branca nos espaços de poder e negro nas bordas da metrópole ${ }^{12}$, constituindo limites distintos nas relações entres negros e brancos. ${ }^{13}$

É nesse processo de fortalecimento de limites distintos entre uma corporalidade e uma subjetividade negras e uma corporalidade e uma subjetividade brancas que ocorre a construção de uma das mais importantes universidades do país, a USP, que materializa o discurso de modernidade a partir da produção do conhecimento científico. O progresso e a ciência são, portanto, os títulos que trazem a necessidade de alavancar todo um projeto de modernidade para o estado de São Paulo por meio das veias da USP. Porém, como já abordado, a instauração desse projeto também foi carregada de uma normatização de limites distintos entre a população negra e a branca. Assim, cabe averiguar como o discurso do progresso dialogou com a prática, principalmente no que tange ao imaginário branco desse território e à ciência, para pensar a universidade que se territorializava na cidade.

\subsection{USP: modernidade e contradição}

Em janeiro de 1934 foi assinado um decreto para a fundação da Universidade de São Paulo. Porém, muito antes dessa assinatura, a universidade já estava sendo construída com as ideias dos intelectuais Júlio de Mesquita Filho e Fernando de Azevedo ${ }^{14}$, que já escreviam textos nas primeiras décadas do século XX sobre a importância de se criar uma universidade em São Paulo.

A derrota de São Paulo na Revolução Constitucionalista ${ }^{15}$ em 1932 é um marco que evidencia não somente o início do desenvolvimento da proposta de criação de uma universidade paulista, mas também o momento em que a disputa pelo poder nacional passaria a ser travada no campo do conhecimento científico. O discurso político foi uma das pontes importantes para nutrir o pensamento sobre a estratégia de uso do saber como arma geopolítica de dominação paulista sobre o território nacional, como ilustra o trecho da

\footnotetext{
${ }^{12}$ O mapa racial da cidade de São Paulo, desenvolvido pelo pesquisador Hugo Nicolau Barbosa de Gusmão em 2016, revela o esvaziamento de pessoas negras do centro da cidade e a concentração destas nas periferias. Ver mais em 〈https://desigualdadesespaciais.wordpress.com〉. Acesso em 14 set. 2019.

${ }^{13}$ Entretanto, apesar da existência desse movimento, o que veremos ainda neste trabalho é que "nem tudo era italiano" (SANTOS, 2017) e que, na virada do século, com suas múltiplas transformações sociais, o espaço urbano de São Paulo será grafado também com sujeitos (movimentos) políticos negros, que organizam e reivindicam seus direitos - sua geografia - ness a cidade paulista.

${ }^{14} \mathrm{O}$ professor Fernando de Azevedo, junto com o jornalista Júlio de Mesquita Filho, fizeram inú meros trabalhos preparatórios, manifestos e inquéritos, promovidos pelo jornal Estado de S. Paulo, para ressaltar a importância da criação de u ma universidade em São Paulo.

${ }^{15}$ A revolução constitucionalista de 1932 foi um movimento que se iniciou em São Paulo contra o governo Getúlio Vargas, quando as elites paulistas buscavam recuperar o comando político nacional.
} 
reportagem "USP, um sonho paulista de 40 anos", publicada no jornal $O$ Estado de S. Paulo, em 1974:

"vencidos pelas armas, sabíamos que só pela ciência e pela perseverança, no esforço, voltaríamos a exercer a hegemonia que durante longa década desfrutarmos no seio da Federação [...] Oras, que maior monumento poderíamos erguer as que haviam consentido no sacrifício supremo para preservar contra o vandalismo [...] do que a Universidade".

(WITTER, 2006, p. 25)

Em alguns momentos, esse discurso político tendia a uma explanação quase que messiânica sobre o papel do Estado de São Paulo e o conhecimento nacional, como aparece em uma reportagem do mesmo jornal em 1934:

"São Paulo tem uma missão dentro da nacionalidade, e essa ninguém pode negar, não será aqui apenas contribuir com sua riqueza para a prosperidade nacional, mas sim a de poder alavancar, dentro de sua população, como pelo país inteiro, o formato de grandes ide ias civilizatórias e inteligentes".

(Ibid., p. 24)

Nesses dois fragmentos, retirados de uma obra comemorativa ${ }^{16}$, podemos observar que a construção da USP tinha como intuito conceber para o território paulista, a partir da ciênc ia, uma hegemonia nacional. Assim, a partir de uma ideologia geográfica (MORAIS, 2005), o Estado paulista alimentou-se de concepções que regeriam a política territorial. A Universidade de São Paulo seria, então, uma alternativa que não se limita ao ato de criação de um polo de desenvolvimento do conhecimento cientifico em território paulista, pois também seria uma alavanca que soergueria o poder fragilizado do Estado com a derrota de 1932.

É essencial salientar que o uso da ciência como uma forma de alcance de um poder hegemônico era apenas um reflexo da "convulsão mundial" (MOTOYAMA, 2006, p. 22) e diretamente relacionado com um projeto de modernidade ${ }^{17}$ que forçava, na escala paulista, transformações que dialogam com os acontecimentos pelo mundo nesse período, marcado por turbulências geopolíticas e econômicas - como revoluções, guerras mundiais, etc. - que, de

\footnotetext{
${ }^{16}$ A pesquisadora Silva (2015) classifica - como u ma forma de diferenciar os diferentes livros que abordam a historiografia da Universidade de São Paulo - essas obras comemorativas em dois grupos: os comemorativos e os analíticos. Os comemorativos seriam aqueles que não buscam analisar a universidade de forma crítica, reiterando "sua importância a partir da afirmação de identidade" (Ibid., p. 272), enquanto os analíticos teriam análises críticas do desenvolvimento histórico da Universidade de São Paulo.

${ }^{17}$ Segundo David Harvey (1990, p. 23), o projeto de modernidade: “entrou em foco durante o século XVII. Esse projeto equivale a um extraordinário esforço intelectual dos pensadores iluministas para desenvolver a ciência objetiva, a moralidade e as leis universais e à arte autônoma nos termos da própria lógica desta. [...] O domínio científico da natureza prometia liberdade da escassez, da necessidade e da arbitrariedade das calamidades naturais. O desenvolvimento de formas racionais de organização social e de modo racionais de pensamento prometia a libertação da irracionalidade do mito, da religião, da superstição, liberação do uso arbitrário do poder, bem co mo do lado sombrio da nossa própria natureza humana".
} 
alguma forma, abalaram o fervor desenvolvimentista da sociedade nesse período (MOTOYAMA, 2006).

No Brasil, essas turbulências foram necessárias para dar caminho em direção a uma industrialização que, mesmo tardia, permitiu um processo de transformação "de um país totalmente agrícola para um modelo econômico mais moderno, mais diversificado" (Ibid., p. 121). Cabia à universidade que se projetava nesse momento permanecer nessa linha de pensamento progressista e

[...] atender aos reclamos da convulsão mundial e as transformações que ocorriam no País. Efetivamente, na década de 20, os limites da política do café com leite ${ }^{18}$ tornavam-se cada vez mais evidentes. O Brasil crescia, provocando, entre outros, o crescimento das cidades e a sua consequente urbanização [...] era muito incipiente no país, necessitando de modernização e de desenvolvimento de parque industrial. (Ibid., p. 23)

Essa necessidade de desenvolvimento era entendida, como já pontuado, a partir de uma lógica marcada por um projeto de modernidade que, em suma, representou também o domínio científico da natureza pelo ser humano, prometendo por meio de um discurso a liberdade da escassez, da necessidade e da arbitrariedade das calamidades vinculadas ao meio natural (HARVEY, 1990). Esse discurso, que possuía a roupagem do desenvolvimento para a organização social e a eliminação das problemáticas humanas via racionalidade do saber e dominação do meio natural, esteve parale lamente vinculado ao projeto de desenvolvimento da Universidade de São Paulo. Essa proposta apresentou, inclusive, características contraditórias que marcaram o pensamento iluminista, trazendo inúmeros problemas que envolveram o projeto moderno. Como salienta David Harvey (1990, p. 24):

O pensamento iluminista internalizava uma imensa gama de problemas e não possuía poucas contradições incômodas. Para começar, a questão da relação entre o meio e os fins era onipresente enquanto os alvos em si nunca podiam ser especificados precisamente, exceto em termos de alguns planos utópicos que, com frequência, parecia tão opressores para alguns quanto emancipadores para outro.

Essa narrativa que rege os meios e os fins para o desenvolvimento do que aqui chamamos de projeto moderno direcionou, consequentemente, problemáticas que estiveram presentes na própria construção da Universidade de São Paulo. Não cabe, pela própria

\footnotetext{
${ }^{18}$ Baseado no rodízio de forças entre Minas e São Paulo, a política do café com leite - café por ser São Paulo o maior produtor de café no início do século XX, e leite por ser Minas o maior produtor de leite no mesmo período -, era u ma disputa pelo monopólio da Primeira República (NEGRO; BRITO, 2013).
} 
estrutura do trabalho, discorrer minuciosamente sobre como se deu essa larga marcha para instauração de uma das principais universidades brasileiras; porém, é necessário fazer uma reflexão a respeito das contradições oriundas desses problemas existentes no projeto moderno e que incidem na relação da universidade com os sujeitos que deveriam ou não ocupar seu espaço, em sintonia com questões que envolvem um projeto ora emancipador, ora opressor.

Vale lembrar que, tão importante quanto compreender a relevância do conhecimento científico da racionalidade como instrumento de respostas das necessidades humanas (HARVEY, 1990), é observar como a universidade serviu, no caso de São Paulo, como projeto para a manutenção do poder territorial paulista sobre a escala nacional, selecionando, consequentemente, quem de fato poderia dominar esse espaço, pois o sujeito que tivesse o domínio científico também exerceria a responsabilidade por toda uma estratégia territorial paulista e nacional. A universidade se tornaria, como efeito dessa seletividade, uma ferramenta não só de elaboração de um projeto de domínio científico paulista, mas também de elaboração de uma classe dominante que reproduziria ideias de uma elite nacional. Dessa forma:

Não se trata de simplesmente ampliar a rede de ensino oficial, nem de mais uma reforma organizada ou curricular. Tratava-se de definir quem educaria os educadores, ou seja, num sentido bem amplo, quem formaria as novas elites intelectuais e dirigentes da sociedade em trânsito, para sua nova fase. (WITTER, 2006, p. 103)

É fundamental pontuar que a universidade, na ótica da elite nacional, se enquadrava em um projeto maior de educação que estava em curso desde o início do século XIX. Esse projeto vinculava a escolarização a um processo de desenvolvimento de uma sociedade desejada por liberais, civis e eclesiásticos que, nesse período, se movimentavam para oferecer ações no campo da cultura e da educação para a população (MACHADO, 2009). Assim, ser um sujeito instruído era visto como algo de grande importância para essa elite que entendia a educação do povo como diretamente relacionada à ascensão da nação (MACHADO, 2009). Porém, na Primeira República, esse discurso progressista apresenta em sua prática uma lógica opressora e excludente de educação não apenas $d a$ população negra, mas sobretudo para a população negra (MACHADO, 2009), pois, contraditoriamente, as políticas educacionais que estavam associadas a uma busca de um sonho utópico de uma elite também se associavam à 
brancura $^{19}$ do povo (DÁVILA, 2006). Nesse sentido, a definição dos sujeitos com o papel de educar quem de fato controlaria não só a universidade, mas também a sociedade, fazia parte de um pensamento recorrente de um grupo intelectual na segunda década do século XX, que acreditava que a evolução da nação estaria atrelada a projetos educacionais ${ }^{20}$ com cunho eugenista $^{21}$ (DAVILA, 2006).

Em sua tese intitulada "Um projeto civilizatório e regenerador: análise sobre a raça no projeto da Universidade de São Pulo”, Priscila Elisabete da Silva (2015) traz à tona o tema da raça e da eugenia ${ }^{22}$ como selos do projeto de construção da USP. Em seu trabalho, a pesquisadora, a partir da análise de alguns arquivos, cartas pessoais escritas pelos principais intelectuais e personagens importantes ${ }^{23}$ para a criação da universidade, revelou a forte identificação dessas pessoas com políticas higienistas, eugenistas e raciais que estavam muito presentes nesse período de criação da universidade:

o eugenismo desempenhou papel central para época, seja ao contribuir para a afirmação do saber médico como o único capaz de guiar a nação ao progresso, seja por colaborar e para a constituição de instituições de controle social e ainda pela influência desenvolvidas junto à implantação de políticas de cunho eugênico. (SILVA, 2015, p. 123)

É importante salientar que, como a pesquisadora mesmo resgata, as ideias eugenistas já estavam sendo grafadas bem antes da construção da Universidade de São Paulo. Essa ideologia foi muito popular ${ }^{24}$ no Brasil nesse período ${ }^{25}$, com o uso da teoria original à moda

\footnotetext{
19 A brancura era "uma forma de afirmar a 'europeidade' que, por sua vez, carregava todas as armadilhas da modernidade, da urbanização à industrialização, racionalis mo, ciência e virtude cívica. Além disso, a brancura transmitia um senso racial de saúde, vigor e superioridade darwinista. A brancura era também, contudo, a ausência da negritude, que era uma afirmação negativa da virtude racial [...] (DA VILA, 2006, p. 27).

${ }^{20}$ Esses projetos educacionais modernos que, já na década de 1920, avançaram com força durante a era Vargas, lançaram "luzes sobre uma das questões mais parado xais do Brasil moderno: como a ideia de que o Brasil era uma democracia racial se tornou o mito orientador da nação durante a maior parte do século XX" (DÁ VILA, 2006, p. 57).

21 Segundo o pesquisado Carlos Eduardo Dias Machado (2009, p. 54), o movimento eugênico descobriu na escola um importante "fórum de gerencia populacional". No imaginário de uma democracia liberal, o uso da ciência no ensino poderia definir não só o futuro da nação como também preparar o "povo" para tal.

${ }^{22}$ Segundo Dávila (2006, p. 31), “A eugenia foi uma tentativa cientifica de 'aperfeiçoar' a população humana por me io do aprimoramento de traços hereditários - noção popular por toda Europa e América no período entre guerras. Os cientistas voltaram-se para a eugenia como uma ciência de ampla abrangência, que combinava diferentes teorias sobre raça, hereditariedade, cultura e influência do meio ambiente em práticas e receitas que visavam 'melhorar' u ma população nacional".

23 Júlio de Mesquita Filho e Fernando de Azevedo apontavam a educação como instrumento de mudança para o povo. Eles se aproximaram da eugenia em um momento em que era forte a associação dessa ideia com a prática de higiene física e social (SILVA, 2015).

${ }^{24}$ Como salienta Dávila (2006, p. 52): "No período entre as duas guerras mundiais, o Brasil foi uma nação seduzida pela ideia de que a ciência poderia ser o árbitro final das relações sociais. Essa causa era defendida por uma crescente casta de cientistas sociais que dominavam as políticas sociais e prometia a aplicação eficaz e imparcial de teorias científicas estrangeiras aos problemas nacionais do Brasil".
} 
brasileira $^{26}$ e a combinação das interpretações do darwinismo social com as perceptivas evolucionistas e monogenistas, para explicar as diferenças e hierarquias (SCHWARCZ, 1993). Assim:

$\mathrm{Na}$ medida em que esse tipo de teoria se transformou no Brasil em uma espécie de jargão comum até os anos 30, tornou-se quase impossível o estudo da totalidade dos intelectuais que opinavam sobre a questão racial. Opção será, dessa maneira tomar os atores não de forma isolada, mas vinculada a diferentes instituições das quais participavam e representavam, por sua vez, seu contexto maior de discurso intelectual. (Ibid., p. 65)

Nesse sentido, o trabalho de Silva (2015) contribuiu para a compreensão não apenas do papele da força do eugenismo nacional no início do século XX, mas também da regulação de normas que estereotipavam o corpo negro e o posicionavam em um lugar inferior, comprovando, desse modo, que uma dessas diferentes instituições que alimentaram essa ideologia do eugenismo foi a Universidade de São Paulo. Mais da metade das cartas que chegavam para o eugenista Renato. $\mathrm{F}$. Kehl ${ }^{27}$ "apresentavam nomes de intelectuais ligados à história da USP" (SILVA, 2015, p. 152), formando uma rede de contato que fortalecia um discurso em que

É possível afirmar que, da parte de figuras que estavam vinculadas às faculdades e instituições ligadas à USP, houve uma boa receptividade para com as ideias eugênicas e para com o eugenista Renato. F. Kehl, fato ocorrido seja antes da fundação dessa Universidade, seja após sua fundação, o que nos conduz a pensar que, tanto pelo vínculo cientifico, quanto pela crença ideológica defendida pela eugenia, os intelectuais e, consequentemente, as instituições que representavam não só estiveram ligados, mas contribuíram para a expansão do movimento eugenista nacional

\footnotetext{
25 A própria América Latina era tratada não como contribuidora, mas como consumidora das ideias e uma consumidora bastante passiva" (MACHADO, 2009, p. 50).

${ }^{26}$ Dávila (2006) pontua que há dois tipos de eugenismo nesse período, o "leve" e o "pesado". Segundo o autor, os eugenistas leves seriam aqueles que aceitavam que a melhoria racial - as mudanças de traços - estava relacionada a cuidados com a saúde, influências ambientais, valores culturais e circunstâncias de reprodução. Os eugenistas "pesados", por sua vez, não aceitavam a modificação de traços e se dedicavam em eliminar os traços indesejados por meio do controle da reprodução. Essas duas divisões estavam associadas a duas vertentes teóricas da genética, a de Lamarck e a de Mendel. Lamarck sustentava que o comportamento e o meio ambiente moldavam os genes, enquanto Mendel acreditava que o material genético poderia ser alterado ao longo da vida. No Brasil, os eugenistas escolheram a genética francesa lamarckinana, que prometia retornos mais imediatos e positivos.

${ }^{27}$ Renato F. Kehl foi u m dos principais eugenistas brasileiros do início de século XX e organizador da Sociedade Eugênica de São Paulo (DÁ VILA,2006). Segundo Silva (2015, p. 150): "O proje to eugênico defendido pelo eugenista nacional, particularmente por Renato F. Kehl, encontrava-se esboçado em um projeto eugênico de educação, is to é, uma concepção de educação construída sob os preceitos da eugenia. Uma visão de educação instrumentalizada para atender aos propósitos de uma construção de uma nação eugenizada, o que era apres entado como sinônimo para civilizado, adiantado, moderno co mo os europeus".
} 
e, particularmente, para a validação das ideias de Renato F. Kehl. (Ibid., p. 184)

Com um maior entendimento sobre as diversas propostas que rodeiam a criação dessa instituição, essa constatação sobre o discurso eugenista tem um significado especial ao revelar que o processo de modernização, como todo processo social, é desigual (SOJA, 1993), agindo de forma diferenciada em cada grupo social. No caso da USP, temos a hipótese de que a existência do diálogo entre pensadores da USP e o eugenista Renato F. Kehl pode ter influenciado a articulação para a criação de uma rede intelectual do pensamento eugênico e pensando a universidade como cons trutora da elite nacional - o projeto de uma elite com uma consciência eugênica (SILVA, 2015), ou de "uma nação moderna e civilizada - "leia-se branca, física e culturalmente" (Ibid., p. 152).

Essa armadilha da modernidade (DÁVILA, 2006) que faz parte do projeto USP conferiu uma tonalidade progressista ao discurso sobre a nação como um projeto de sociedade. Porém, com um olhar mais preciso, visualizamos que toda essa manifestação sobre o que é ou não ser civilizado é carregada de contradições opressoras, como afirma o professor David Harvey (1990). Essa dimensão também revela que, mesmo biologicamente inexistente, raça foi e ainda é sustentáculo das relações sociais que envolvem não só a instituição universitária sobre a qual estamos nos debruçando, mas também toda uma discussão a respeito da formação territorial da população brasileira. Dessa forma, pensar a comunidade negra $^{28}$ que ocupa a Universidade de São Paulo, no campus Butantã, sem fazer essa análise sobre os conceitos de raça, racis mo e eugenismo nas relações e tensões que estão incorporadas na sociedade e no interior dos muros da USP, esvaziaria toda uma possibilidade de debate que enriquece o trabalho e que estamos buscamos com esta pesquisa.

Para concluir essa primeira análise sobre o território da USP, entendemos que a compreensão, a formação e as contradições entre o pensamento dos intelectuais paulistas e o ideário moderno dão sentido e direcionamento ao estudo. Nesse sentido, a pesquisa não apenas compreende de forma material os caminhos que tornaram possível a fundação de um território universitário marcado espacialmente e cercado por muros na zona oeste da cidade de São Paulo, como também permite interpretar historicamente como foram tecidas algumas narrativas que estão nas entrelinhas da história e que, de alguma forma, estão atreladas às

\footnotetext{
28 Lembrando que nosso recorte se baseia na análise de trajetórias de servidores(as) técnico-administrativos, professores e alunos e alunas de diferentes faculdades.
} 
temáticas que envolvem a Universidade de São Paulo e às diversas relações de poder dentro dela que se refletem na configuração do corpo negro nes se território.

\section{A configuração do corpo negro no território da USP}

A maneira como a população negra - estudantes, servidores(as) e docentes - usa e ocupa o território da USP projeta, para a investigação deste trabalho, uma perspectiva necessária para a leitura da geografia das relações étnico-raciais no campus do Butantã. Nesse sentido, optamos por uma análise quantitativa para identificar como se dá a presença desses sujeitos que marcam o território de uma das maiores universidades do Brasil.

A importância da busca e da construção de uma análise atual sobre a configuração da população negra no território do campus Butantã é um princípio norteador para o entendimento das contradições que estão materializadas dentro das universidades e que, a partir de uma profunda investigação, podem ser também um eixo condutor para compreensão das relações raciais brasileiras.

O primeiro desafio para a realização dessa análise foi encontrar dados referentes à distribuição étnico-racial dos sujeitos negros na universidade. Ao buscar o recorte dessas informações pelos acessos diretos - sites, livros oficiais da universidade ou até mesmo matérias audiovisuais sobre a instituição - nos deparamos com um penoso caminho, que exigiu um garimpo de dados em que pouco ou quase nada se tinha acerca do que precisávamos. Apesar da existência da Lei Estadual n. 14.187, contra a discriminação racial, da Lei n. 16.279/16, referente ao Plano Estadual de Educação, em que um dos princípios é a promoção da diversidade étnico-racial, e do Decreto de Lei 44.228/02, no âmbito das instituições públicas federais, com o programa de ações afirmativas, leis que justificariam a necessidade de acesso a fontes diretas para avançar nas questões relacionadas às desigualdades raciais, o esvaziamento dos dados é ainda uma constante regra nas pesquisas ligadas à população negra.

No caso da composição negra da USP, mesmo com esses avanços provocados por leis, a dificuldade de encontrar referências determina uma realidade de inexistência ou de ocultamento dos dados do banco oficial da instituição. A invisibilidade de uma característica dessa natureza, "num espaço de produção e transformação de conhecimento sobre a sociedade" (OSÓRIO, 2004, p. 36), como a USP, já tem sido apontada por diversos trabalhos 
como um dos sintomas decorrentes do racismo institucional ${ }^{29}$ (OSÓRIO, 2006; SILVA, 2015; GONZAGA, 2001; TEIXEIRA, 1998). A ausência de um diagnóstico a respeito das desigualdades étnico-raciais por parte da USP apenas reforça o mito presente no discurso sobre a democracia racial brasileira, a partir do qual, em valores quantitativos, negros e outros grupos estariam espacialmente justificados como iguais.

A despeito do portal da transparência da universidade contribuir com alguns documentos assegurados pela Lei Federal de Acesso à Informação n. 12.527/11 e pelo Decreto Estadual 58.052/12, esses dados encontram-se espaçados no que tange aos atributos dos estudantes e diluídos quanto à distribuição étnico-racial da universidade.

Ainda sobre os dados coletados de forma direta, tivemos acesso a uma outra plataforma importante, que é a da FUVEST; porém, as referências cedidas pelo órgão apenas possibilitam a identificação de alunos e alunas que tiveram aprovação em um dado momento e não necessariamente delimita aqueles que estão materializados efetivamente nas diversas faculdades do território da USP Butantã. Para isso, optamos em recorrer a dados indiretos aqueles cedidos via pedido - da Pró-Reitoria de Graduação, que, como um dos órgãos centrais da universidade no quesito planejamento e acompanhamento dos conhecimentos relacionados a diretrizes da vida dos estudantes, permite a "(des)invisibilidade" dos registros de cor dos estudantes e dos espaços ocupados.

No caso dos servidores(as) da USP, optamos por um caminho diferente em relação ao caminho adotado sobre os(as) estudantes. Os dados referentes aos servidores foram requisitados pelo Portal de Transparência do Governo do Estado de São Paulo, já que os trabalhadores(as) da USP também se enquadram como servidores públicos do Estado.

O segundo desafio se fez presente na organização dos dados recebidos. A sistematização a partir do uso de filtros normais e planilhas dinâmicas em aplicativos como o Excel possibilitaram a organização daquilo que tínhamos de mais precioso para uma leitura fundamentada no "enegrecimento" dos dados. Para isso, tivemos que adequar as informações recebidas ao sistema de classificação de cor/raça do IBGE (OSORIO, 2003), já que não estavam devidamente unificados de acordo com os parâmetros do Censo de 2010.

O sistema do IBGE tem adotado, desde 2010, a agregação das subcategorias Preto e Pardo para a formação da categoria Negro, pois entende-se que o papel da classificação racial

29 Segundo Gonzaga (2011), o racismo institucional pode ser identificado como normas, práticas e comportamentos discriminatórios adotados no espaço do trabalho - como na USP -, sendo resultado da ignorância, da falta de atenção, do preconceito ou de estereótipos racistas. 
não é estabelecer com precisão um tipo biológico, mas se apoiar em uma característica sociocultural e socioeconômica dos dois grupos, que possuem os mesmos potenciais e sofrem com problemas da mesma natureza (OSÓRIO, 2003). Assim, unificamos pretos e pardos nos dados cedidos tanto pelo governo do Estado quanto pela Pró-Reitoria de Graduação, pois compreendemos também que as desigualdades entre os dois grupos são comuns e qualquer ação que seja tomada no sentido de reverter o quadro histórico de desigualdade racial (OSÓRIO, 2003) dentro da universidade deve ser analisada de forma conjunta.

O terceiro desafio será apresentado na próxima parte do trabalho, em que, a partir da combinação e articulação dos dados coletados em 2018, analisaremos o corpo de es tudantes e de trabalhadores(as) negros(as) da USP para aprofundar nossas leituras sobre a ocupação e o uso que esses sujeitos fazem da Cidade Universitária.

\section{.1 Os/as estudantes negros/as da USP}

Em 2018, quando os dados foram coletados, a Cidade Universitária possuía um total de 29.897 mil estudantes de graduação em seu território. Esse contingente populacional reafirma, em números, a importância da Universidade de São Paulo como uma das principais universidades do país e levanta, já de início, a necessidade de entender a fundo esse contingente no que diz respeito ao aspecto étnico-racial.

Inicialmente, para conseguirmos fazer uma análise do corpo discente negro, tivemos que unificar os dados dos estudantes pretos e pardos e, assim, termos uma primeira observação a partir do sistema de classificação do IBGE. O resultado foi o gráfico abaixo:

Gráfico 1- Distribuição étnico-racial dos estudantes da USP - Butantã

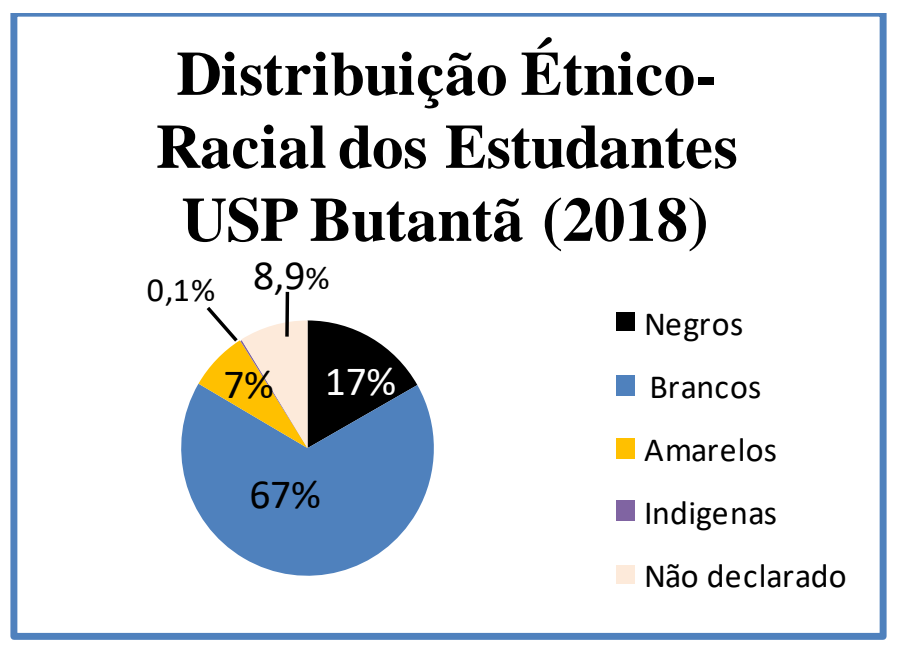

Fonte: Elaborado pelo autor (2018). 
O gráfico indica como está sendo a distribuição em porcentagem dos estudantes do campus Butantã em 2018. Como salientado por documentos oficiais do município ${ }^{30}$ de São Paulo, a desigualdade de gênero e cor/raça é um fenômeno que afeta diretamente os segmentos negros da população da cidade. No gráfico do recorte do território da USP, vemos que essas diferenças entre grupos étnicos também se mantêm na universidade. Como pode ser observado, a população branca de estudantes é a mais expressiva, correspondendo a $67 \%$, o que, em números de pessoas, representa aproximadamente 19.967 pessoas. Os estudantes negros - somando pretos e pardos - correspondem a 4.994 alunos/as, o que é sinalizado pelos $17 \%$ aproximados do gráfico. O menor contingente é, por sua vez, dos povos indígenas, sendo apenas $0,1 \%^{31}$ do total de estudantes da USP.

Ao fazermos uma comparação entre a população negra e o grupo em destaque da USP, temos uma diferença que chega a ser aproximadamente 4 vezes maior, ou seja, em 2018, para cada negro dentro do território do Butantã, temos quase quatro estudantes brancos (Gráfico 2).

A realidade da distribuição étnico-racial da cidade de São Paulo e a existente dentro do campus Butantã podem trazer também uma face interessante para a reflexão, pois, a partir dos dados publicados pela Secretaria Municipal de Igualdade Racial da Prefeitura de São Paulo, em 2016, vemos que os valores que mais se aproximam são aqueles encontrados em relação ao percentual de população branca no município - 60,6\% dos habitantes da cidade. É interessante essa comparação, uma vez que, ao nos voltarmos para a população negra, observamos que esta possui um porcentual muito maior fora dos muros do território uspiano do que dentro dele, correspondendo a $37 \%$ dos habitantes de São Paulo ${ }^{32}$. Essa constatação levanta uma discussão acerca da representatividade populacional do campus que, ainda, em 2018, não parelha com a realidade do seu entorno:

\footnotetext{
${ }^{30}$ Um importante fórum de análise desses dados sobre as desigualdades raciais na cidade de São Paulo é o Fórum de Desenvolvimento Econômico Inclusivo, criado pela Secretaria Municipal de Promoção da Igualdade Racial na Prefeitura de São Paulo (SMPIR), que tem como objetivo contribuir com o desenvolvimento socioeconômico da população afrodescendente na cidade de São Paulo

${ }^{31}$ Este é um dado muito importante, embora a pesquisa não tenha se aprofundado nele, pois retoma a ideia de eliminação populacional, pensada por Abdias do Nascimento (2016), processo calculado de forma especifica e estratégica para a população negra e que se reflete em dados demográficos que "iluminam os mecanis mos deste linchamento social" (Ibid., p. 89).

${ }^{32}$ Segundo o Censo de 2010, a cidade de São Paulo é a que possui maior o número de negros no país $(4,2$ milhões).
} 
Gráfico 2 -Total de estudantes negros e brancos em 2018 na USP - Butantã.

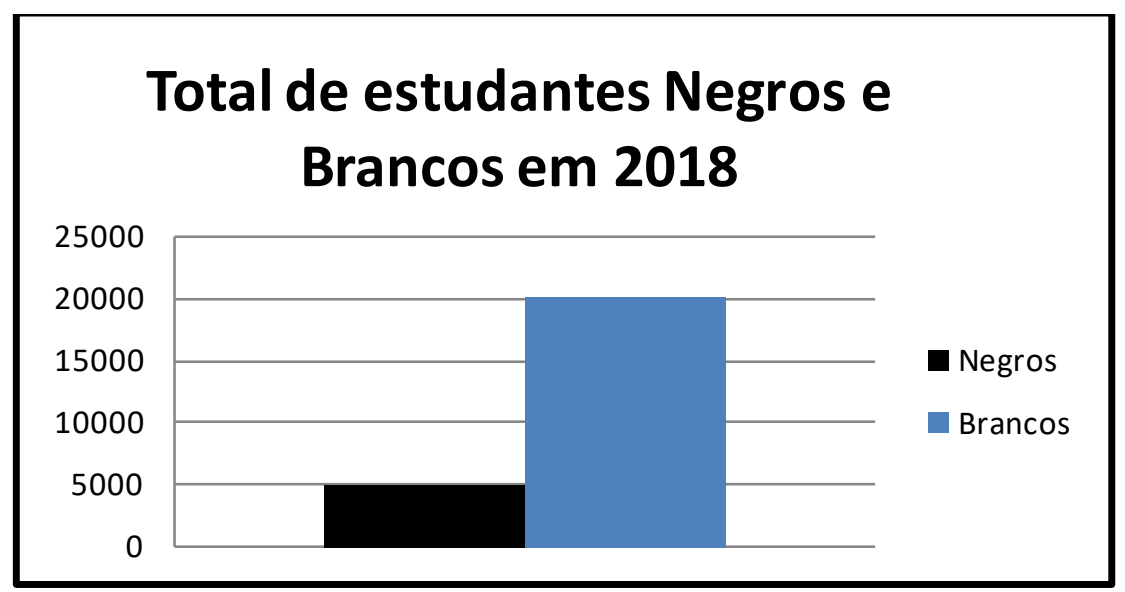

Fonte: Elaborado pelo autor (2018).

Outro importante olhar sobre esse dado se refere à questão de gênero dentro do campus. Do total de estudantes da universidade, aproximadamente $57 \%$ representavam a população de homens e $43 \%$ de mulheres. No contexto do racismo, em que as relações são medidas de forma assimétrica e hierárquica (GONZALES, 1984), cabe também fazer um recorte que envolva as alunas negras do campus, pois, no total de estudantes negros, 2.045 são mulheres negras, representando, as sim, aproximadamente $40 \%$ dos estudantes negros da USP Butantã. O gráfico 3, a respeito da distribuição étnico-racial por gênero, permite também partilhar que, apesar das diferenças de gênero entre homens e mulheres nos valores totais de alunos do campus, as mulheres brancas ainda estão numericamente acima do total da população negra e das mulheres negras:

Gráfico 3- Distribuição étnico-racial por gênero na USP - Butantã (2018)

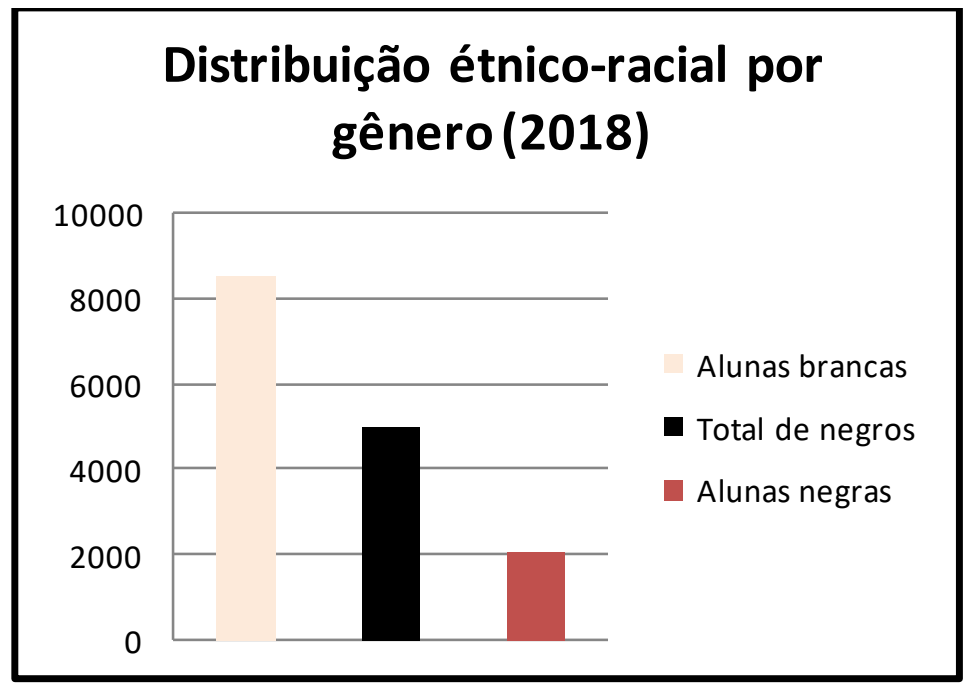

Fonte: Elaborado pelo autor (2018). 
Além dos números gerais, o debate que tentaremos fazer a partir de agora é sobre a configuração dos espaços ocupados pelos estudantes negros. Entendemos esses espaços como sendo as faculdades, escolas e institutos que estão materializados por toda a Cidade Universitária, com sua diversidade de cursos. Interpretamos as escolhas comuns de curso como um fator possível para compreensão das relações étnico-raciais e do ensino universitário. O resultado dessa espacialização foi o mapa de distribuição da densidade de estudantes negros(as) na USP-Butantã em 2018, enquanto o Gráfico 4 representa os cursos ocupados pelos(as) estudantes negros(as).

O mapa de calor permite compreender como e onde se apresentam os espaços de maior ou menor densidade de estudantes negros(as) da USP, 58specializando, a partir de pontos quentes (hot points), como os(as) estudantes negros(as) do campus têm territorializado a universidade No caso desse mapa, as áreas que estão em branco representam espaços sobre os quais a pesquisa não conseguiu dados, já as áreas em amarelo são lugares onde a presença negra é baixa. É importante salientar a predominância das manchas amarelas juntamente com as laranjas escuras, vermelhas e as na cor vinho, palhetas de cores que, no mapa, simbolizam as faculdades e institutos onde os(as) estudantes negros(as) estão se concentrando e, por isso, estão em destaque no mapa. A predominância da coloração amarelada no mapa do território da USP Butantã reafirma, por sua vez, os gráficos que se referem à totalidade distributiva de estudantes negros(as) no campus.

Ao listarmos os espaços ocupados pelos(as) estudantes negros(as) em 2018, temos uma representação gráfica que destaca as escolhas feitas e os espaços ocupados por eles(as) no campus, abarcando três colunas de destaque para a investigação, que nada mais são do que as principais áreas de escolha desses estudantes. A coluna mais expressiva do gráfico é a da Faculdade de Filosofia, Letras e Ciências Humanas(FFLCH), com um total de 1.948 estudantes, a maioria nos cursos de História e Geografia do período noturno e, logo em seguida, em ordem decrescente, a Escola Politécnica(EP), com 559 estudantes e, em terceiro lugar, a Escola de Comunicação e Artes (ECA), com 441. 


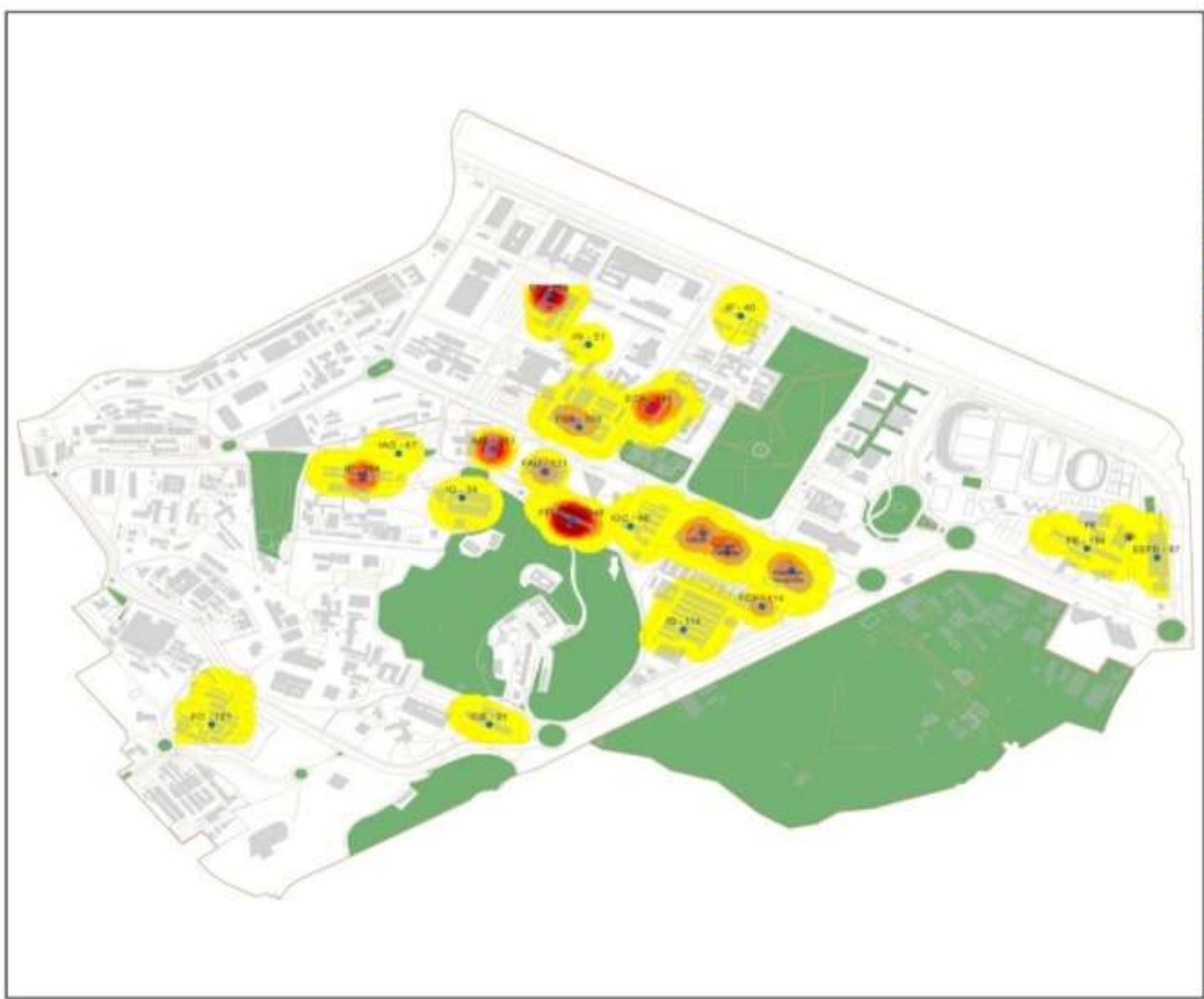

Legenda

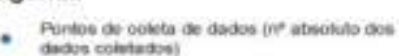

- Parata on onteur

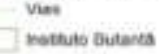

Eatroapbes

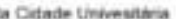

Den hivas veeder

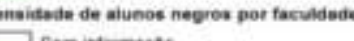

Siem indormasto

Nite

Muts anta

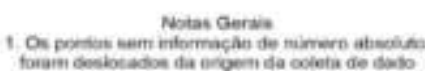

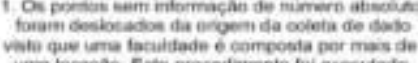

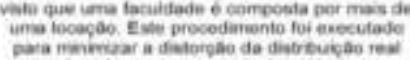

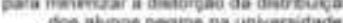

Figura 3-Mapa de distribuição da densidade de estudantes negros(as) na USP-Butantã em 2018 Fonte: Elaborado pelo autor (2018). 
A concentração de estudantes negros/as nesses espaços do território da USP representa um sintoma que, para o presente trabalho, escapa do campo das escolhas individuais e traça uma oportunidade para o aprofundamento das questões que desembocam no debate sobre o negro dentro da universidade. Em seus estudos sobre a USP e as desigualdades, Dilcele Mascarenhas Queiroz (2004) nos ajuda a responder os motivos que fariam os negros estarem ocupando majoritariamente a FLLCH. Segundo ela:

Os negros, mesmo aque les que conseguiram ingressar na universidade, são, de modo geral, pessoas que vêm de uma origem social social modesta, que frequentaram escola de primeiro e segundo grau de ensino precário, cuja escolha da carreira universitária recai, frequentemente, sobre aquelas menos valorizadas e menos concorridas, sobretudo nas áreas de Humanas. (Ibid., 2004, p. 65)

Sendo a FFLCH a faculdade que possui a maior concentração de cursos da área de Ciências Humanas, ou seja, com forte nível de criticidade sobre a sociedade, observar no gráfico de ocupação uma territorialização mais intensa da presença negra nesse espaço pode ser um indício que relaciona carreira e demandas sociais com o sujeito e sua trajetória no vestibular. Mesmo sabendo que a maioria dos cursos de Ciências Humanas tendem a serem postulados, em uma visão capitalista, como cursos de "menor valor", são eles os que permitem minimamente ofertar respostas sobre as mazelas sociais e aproximar os grupos minorizados, como no caso da população negra. Outro ponto importante, levantado pelos dados da FFLCH, é o fato de a maioria dos estudantes negros escolher cursos noturnos, o que reforça a relação entre trabalho e estudo, conciliados na vida da grande parte desses(as) alunos(as) negros(as). 
Gráfico 4-Espaços ocupados pelos estudantes negros na USP - Butantã (2018)

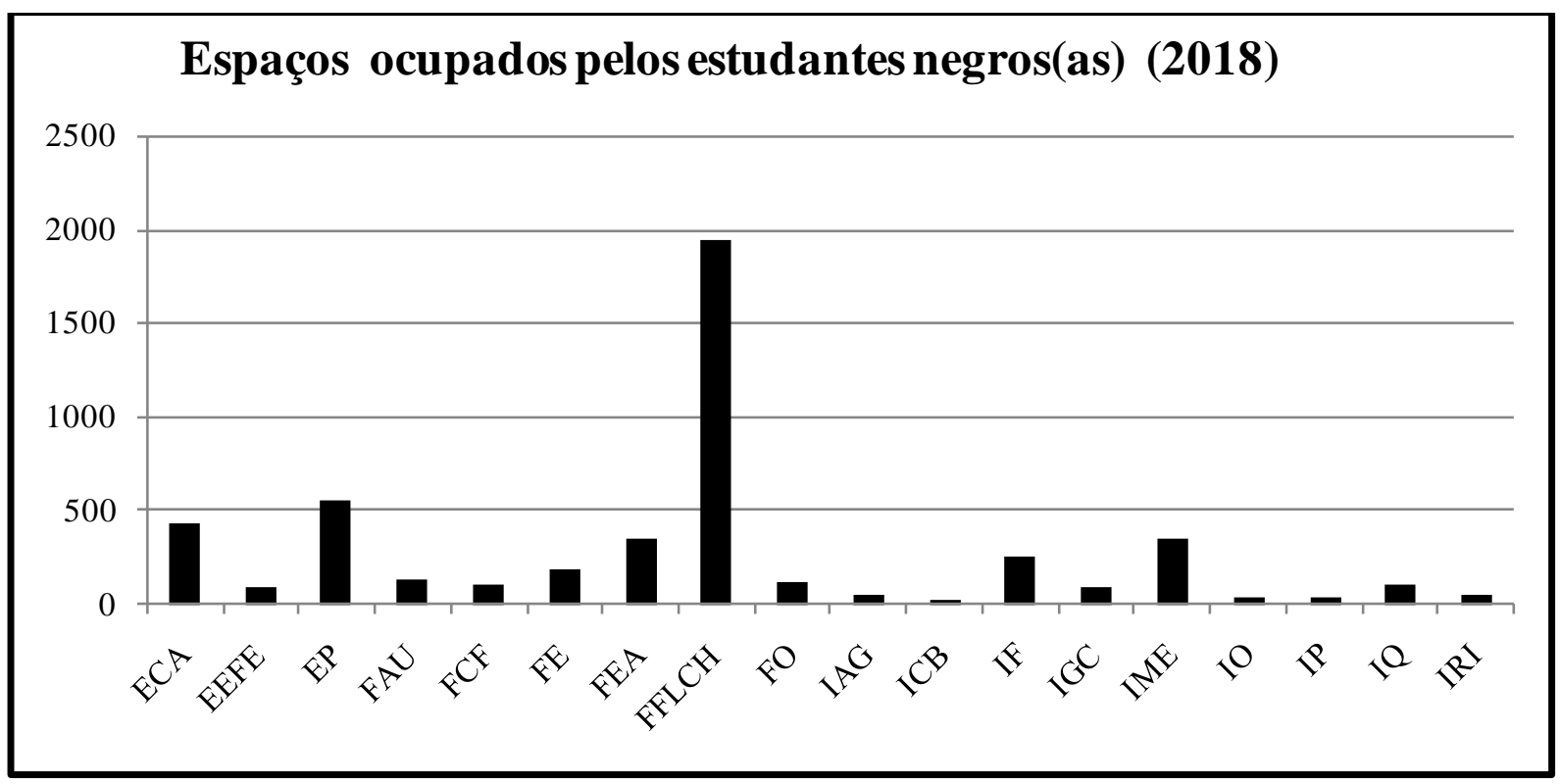

Fonte: Elaborado pelo autor (2018).

O segundo espaço no território da Cidade Universitária onde se tem maior presença negra é a Escola Politécnica (EP). Em um primeiro olhar, esse dado pode causar dois sentimentos no leitor: o sentimento de contradição e o de comemoração. A contradição se refere ao contraponto em relação à exposição dos dados da FFLCH, quando se argumentou que os(as) estudantes negros(as) estariam optando por cursos com uma menor concorrência no vestibular, enquanto o sentimento de comemoração viria por parte dos diversos movimentos sociais que lutam pela integração dos grupos minorizados em cursos ditos de "elite". Porém, um olhar cauteloso do observador pode revelar uma miragem quantitativa. Mesmo os dados apontando a EP como um espaço de concentração negra, isso não significa que, em um resgate da totalidade dos estudantes da faculdade, esse grupo seja expressivo. $\mathrm{Na}$ verdade, quando fazemos um paralelo com o grupo majoritário (Gráfico 5), temos, por exemplo, uma diluição da presença negra. Portanto, se por um lado os dados evidenciam a importância da EP como um espaço onde se tem, entre a população negra universitária, um contingente significativo de territorialização de sujeitos negros/as; por outro, quando esses mesmos números são emparelhados com os estudantes brancos(as), essa realidade é colocada em xeque. 
Gráfico 5- Comparação entre negros e brancos na Escola Politécnica na USP - Butantã (2018)

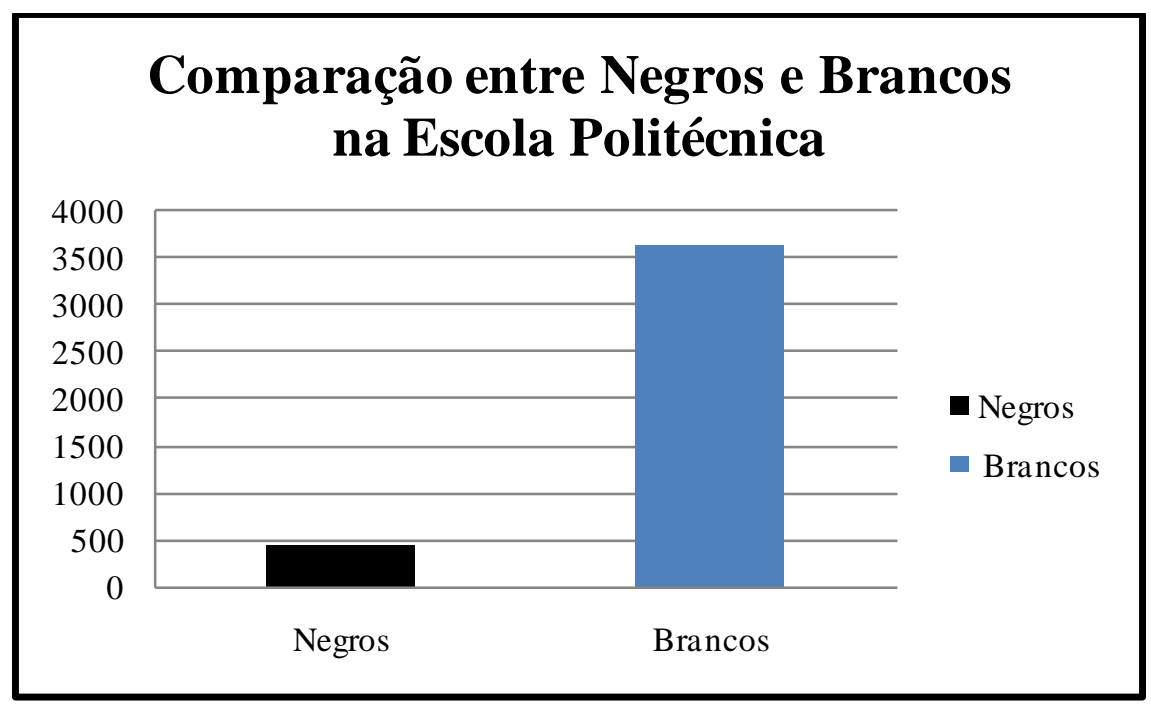

Fonte: Elaborado pelo autor (2018).

Quando nos propomos a fazer um recorte de gênero dos dados referentes aos estudantes negros(as) da USP, temos uma ligeira mudança na estrutura organizacional do gráfico sobre os espaços ocupados por eles. No gráfico das alunas negras (Gráfico 6), há um deslocamento de posições de maior densidade e o afloramento de outros espaços que, nos dados gerais, aparentavam serem mais baixos. Nessa observação, a FFLCH continua sendo a faculdade onde se tem uma maior quantidade de mulheres negras no território, enquanto a mudança ocorre na EP, que deixa de ser o segundo lugar para se tornar o quarto, e a ECA, que antes era a terceira, se torna o segundo espaço mais ocupado pela mulher negra. A novidade chega na terceira coluna que, para as alunas, é representada pela Faculdade de Educação (FE). A mudança de posições das colunas é, nesse sentido, um resultado direto do machismo na representatividade feminina em determinas profissões, pois mesmo em ascensão (BASTOS, 2017) a presença das mulheres negras em determinados espaços, como a FE, e a reduzida presença em outros, como em EP, revelam o papel ativo do machismo na delimitação das mulheres negras em determinados cursos e formações do campus da USP. 
Gráfico 6 -Espaços ocupados por alunas negras na USP - Butantã (2018)

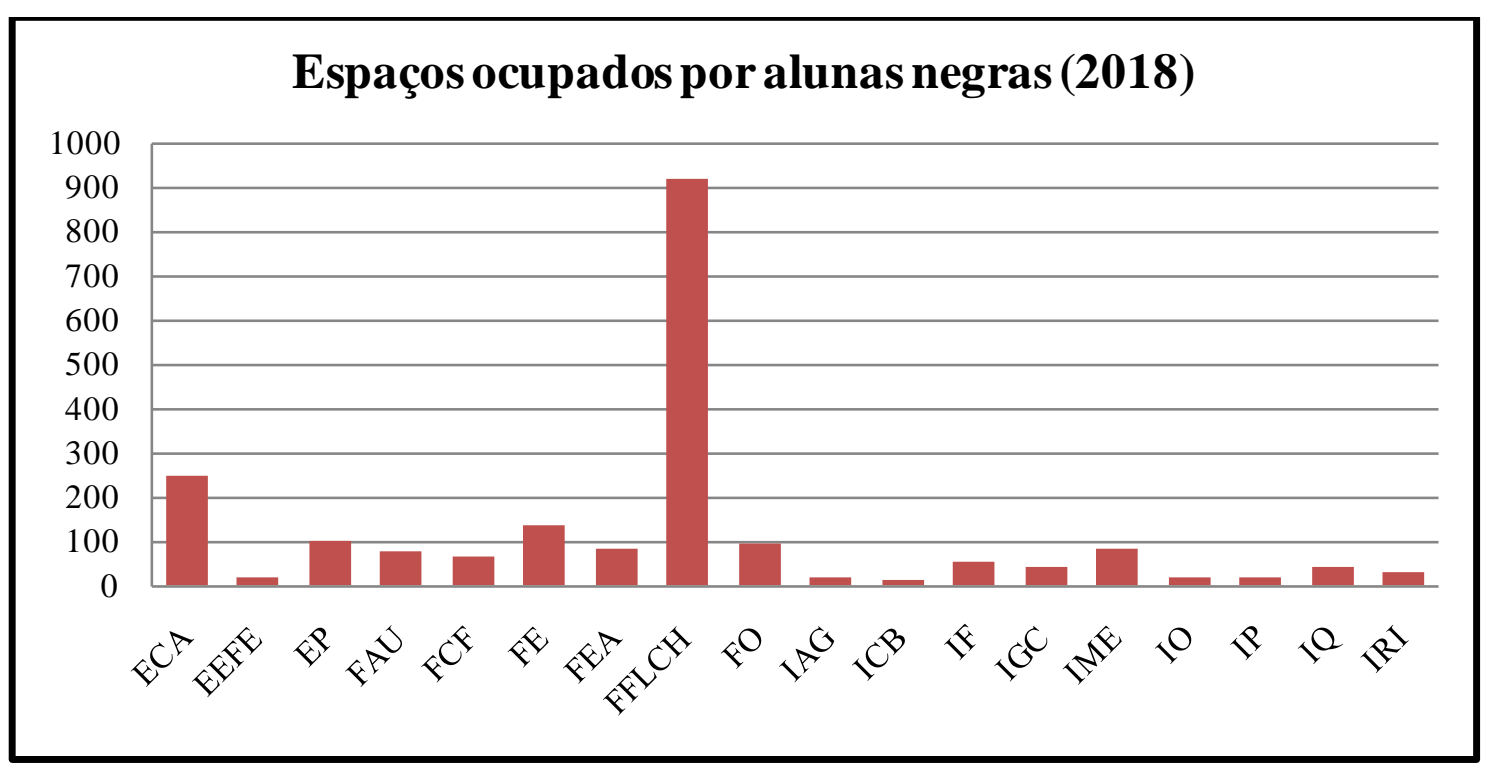

Fonte: Elaborado pelo autor (2018).

As características formalizadas pela combinação e articulação dos dados dos estudantes de graduação da USP se concretizaram em gráficos e no mapa de espacialização/ocupação dos negros na universidade. As territorializações de alunos(as) negros(as) nas diferentes escolas, faculdades e institutos permitiram uma análise da presença e da ausência deles que contribui para uma reflexão sobre as desigualdades étnico-raciais dentro do território da USP. Entretanto, essa investigação não se encerra em uma mirada a respeito dos estudantes de graduação, pois é necessário traçar um paralelo com outra categoria para nos aproximarmos de um parâmetro do corpo negro na Cidade Universitária. Assim, como continuidade desse processo de análise, seguiremos agora com os(as) servidores(as) para não reduzir as aglomerações negras à condição de estudantes, incluindo, então, trabalhadores(as) que igualmente circulam dentro do território e produzem um rico debate sobre os espaços de poder da universidade.

\section{.2 Servidores/as negros/as}

A categoria "trabalhador" permite conferir outro tom ao território universitário. Mesmo em diferentes papéis no campus, os/as servidores/as possuem uma ligação com as escolhas dos espaços de trabalho, em que a diferença entre estudantes e servidores é, por 
exemplo, o tempo de permanência no território, pois ser funcionário/a público é vivenciar um tempo maior dentro do território. Outra diferença é a estrutura de funcionamento que rege a presença dos trabalhadores. Aqui, iremos nos basear na estrutura oficial do Departamento de Recursos Humanos da USP; porém, para nossa interpretação de dados, a única diferença será a forma como observaremos essas informações, já que optamos por não fazer uma distinção direta entre docentes e trabalhadores técnico-administrativos do campus, entendendo que, para o racismo institucional, não existe uma diferença entre dois grupos.

$\mathrm{O}$ encontro de dados referentes à configuração étnico-racial dos(as) servidores(as) negras(os) da Cidade Universitária da USP se deu através do recadastramento anual feito pelos servidores públicos do Estado de São Paulo. Escolhemos esse caminho porque possibilita uma atualização anual dos dados cadastrais dos(as) servidores(as) que estão na ativa dentro do campus, inclusive dados diretos referentes à opção por cor/raça dos trabalhadores(as). Assim, o primeiro resultado da coleta de dados pode ser visto abaixo:

Gráfico 7 - Configuração étnico-racial dos(as) servidores(as) da USP no campus Butantã

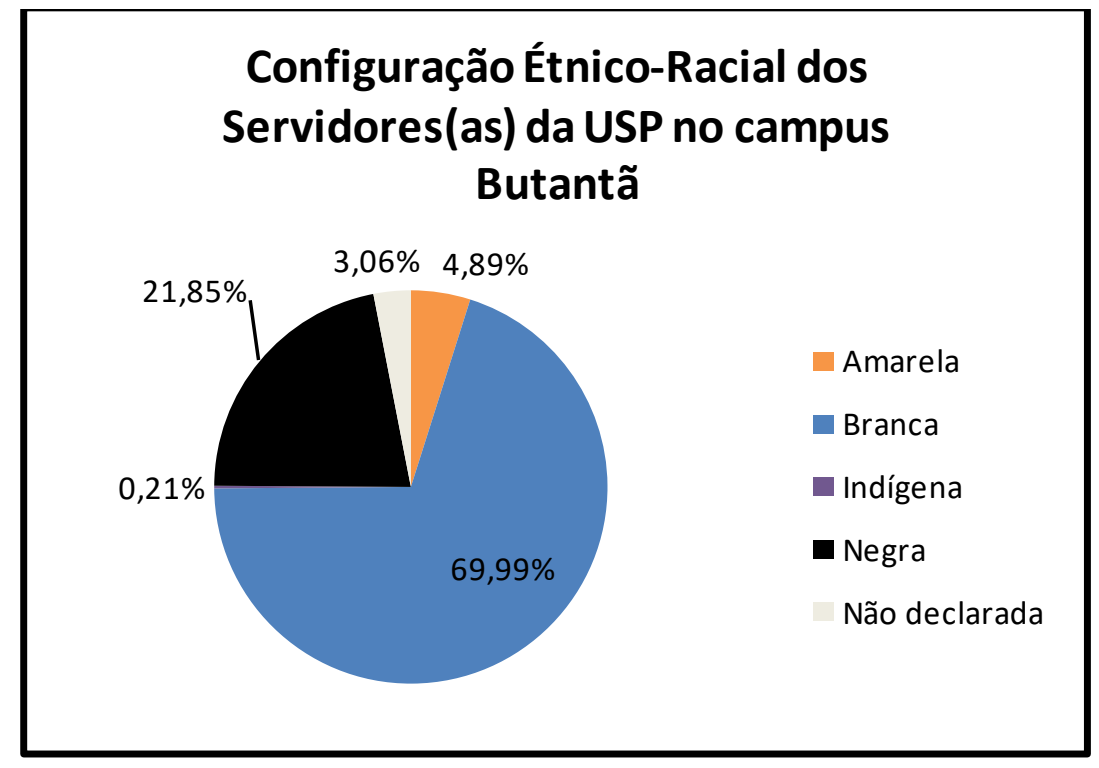

Fonte: Elaborado pelo autor (2018).

Essa primeira organização dos dados colhidos revela como se dá a divisão étnicoracial dos(as) servidores(as) do campus Butantã. De acordo com os dados, o grupo em destaque, ocupando um total aproximado de 69,99\%, é a população branca, que corresponde a um total de 5.886 pessoas. Em seguida, com 1.837, temos $21,85 \%$ de pessoas que se autodeclaram negras. O gráfico também mostra que, entre os(as) trabalhadores(as) da USP, $4,89 \%$ se consideram amarelo, o que equivale a um total de 411 pessoas e, expressivamente, 
existem 3,06\% de pessoas - 257 em números -, que não optaram por nenhumas das opções de autodeclaração étnico-racial. Em menor porcentual, temos os indígenas, com, 0,21\%, ou seja, 18 pessoas, e que reflete aquilo que já apontamos ao delinear o perfil dos estudantes, mesmo nesse caso o número sendo ligeiramente maior.

Apesar de saber das diferenças populacionais existentes entre os(as) servidores e os(as) graduandos do campus, existe, entre os dois grupos, uma proporcionalidade porcentual na configuração étnico-racial que se mantém. Dessa forma, o percentual de servidores brancos se assemelha ao existente entre os estudantes do mesmo grupo étnico-racial (67\%), e a diferença entre estudantes e servidores negros é pequena, quase 5\%. Outro dado importante é referente àqueles que não se autodeclaram, pois, diferentemente dos estudantes, os trabalhadores estão mais conscientes quanto à autodeclaração. No território da USP, a proporção de amarelos, por sua vez, parece estar mais presente no grupo de estudantes do que no grupo de servidores. Essa manutenção dos valores percentuais das duas categorias estudadas se reflete, consequentemente, na desigualdade, já discutida no trabalho, referente à configuração étnico-racial fora do território e que ainda não possui, proporcionalmente, equiparação no que diz respeito ao espaço analisado neste trabalho.

A organização desses dados coletados deu origem a uma geografia dos espaços ocupados por esses servidores negros no território da USP e que foi materializada na figura abaixo: 

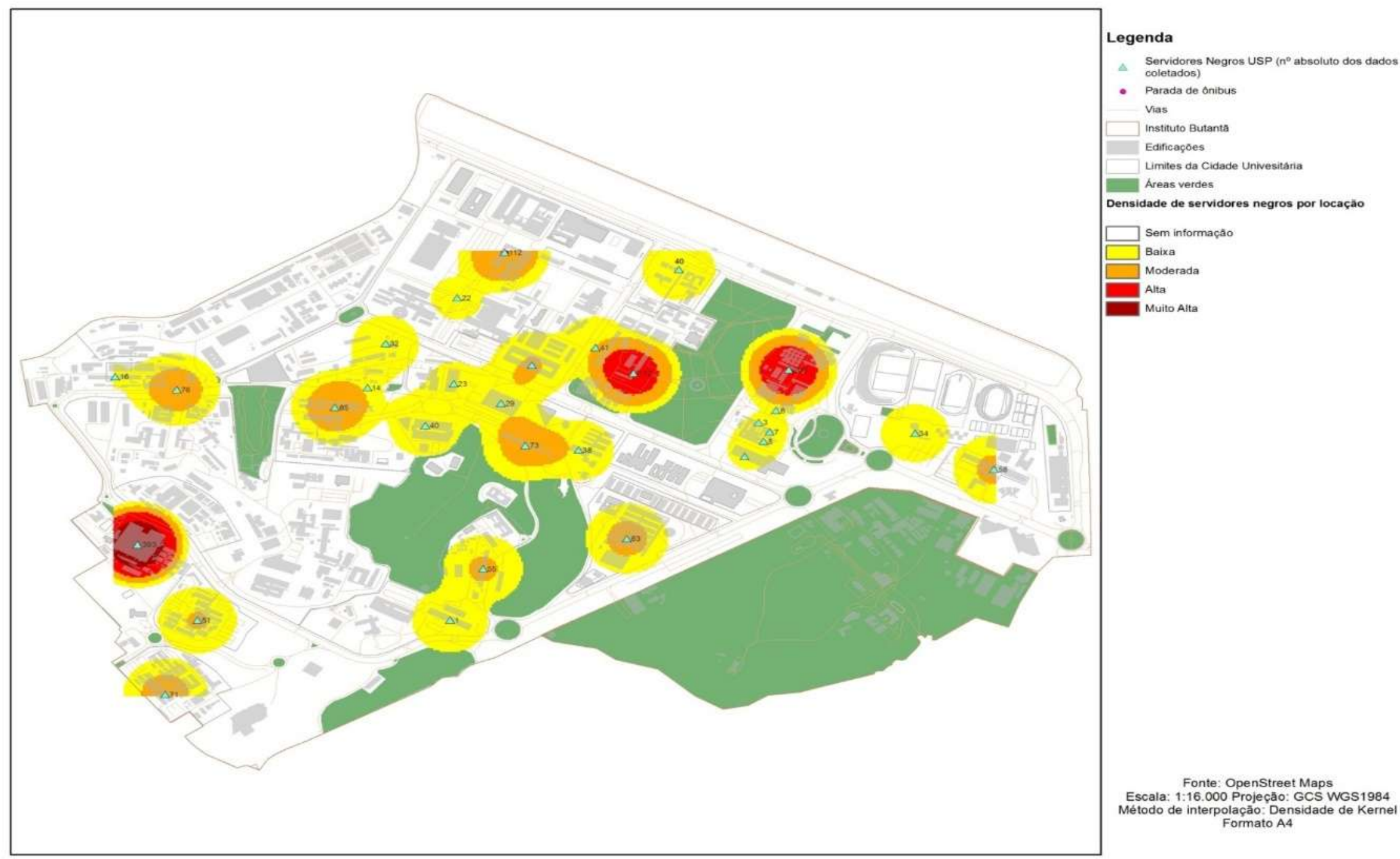

Figura 4 - Espaços ocupados pelos servidores negros/as no território da USP (2018). Fonte: Elaborado pelo autor (2018). 
O mapa do território da Cidade Universitária acima permite que, a partir das manchas de calor, possamos identificar os espaços que possuem maior ou menor densidade de servidores negros dentro do campus, em que as manchas respeitam uma ordem da temperatura que envolve as cartelas de cores selecionadas. Assim, no espectro de cor do mapa, na ordem crescente, temos a cor branca, referenciando espaços da universidade onde a presença de trabalhadores negras é muito baixa e, em seguida, espaços amarelados, onde a densidade não é muito baixa, mas continua em níveis baixos. Os espaços laranjas do mapa são, por sua vez, espaços onde a ocupação é moderada e, por fim, as cores vermelha e vinho sinalizam os espaços que de fato possuem uma densidade alta ou muito alta.

A disposição das cores no mapa denuncia como e onde os(as) servidores(as) negros(as) estão localizados na USP. Em um primeiro olhar, é possível identificar três manchas avermelhadas no mapa, os pontos quentes do mapa (hot points), que marcam os espaços onde se tem uma maior densidade de servidores públicos negros da USP. Assim, a partir desses pontos quentes, temos que os espaços com maior presença negra são o Hospital Universitário, a Superintendência de Assuntos Sociais e a Reitoria da USP. Apesar desses pontos tomarem lugar de destaque, é importante perceber que, na organização das cores do mapa, aquela que prevalece é a branca, indicando que, mesmo com a existência de três pontos quentes, ainda existe uma baixa densidade de servidores negros ocupando o território em sua totalidade. Os pontos amarelos/alaranjados distribuem uma variedade de manchas que se concentram no centro do território e se diluem em suas bordas.

Quando trazemos essas informações em valores gráficos, temos a possibilidade de observar com mais detalhe essa distribuição negra no campus: 
Gráfico 8 -Total de servidores/as negro(as) por espaço ocupado no território da Cidade Universitária (2018)

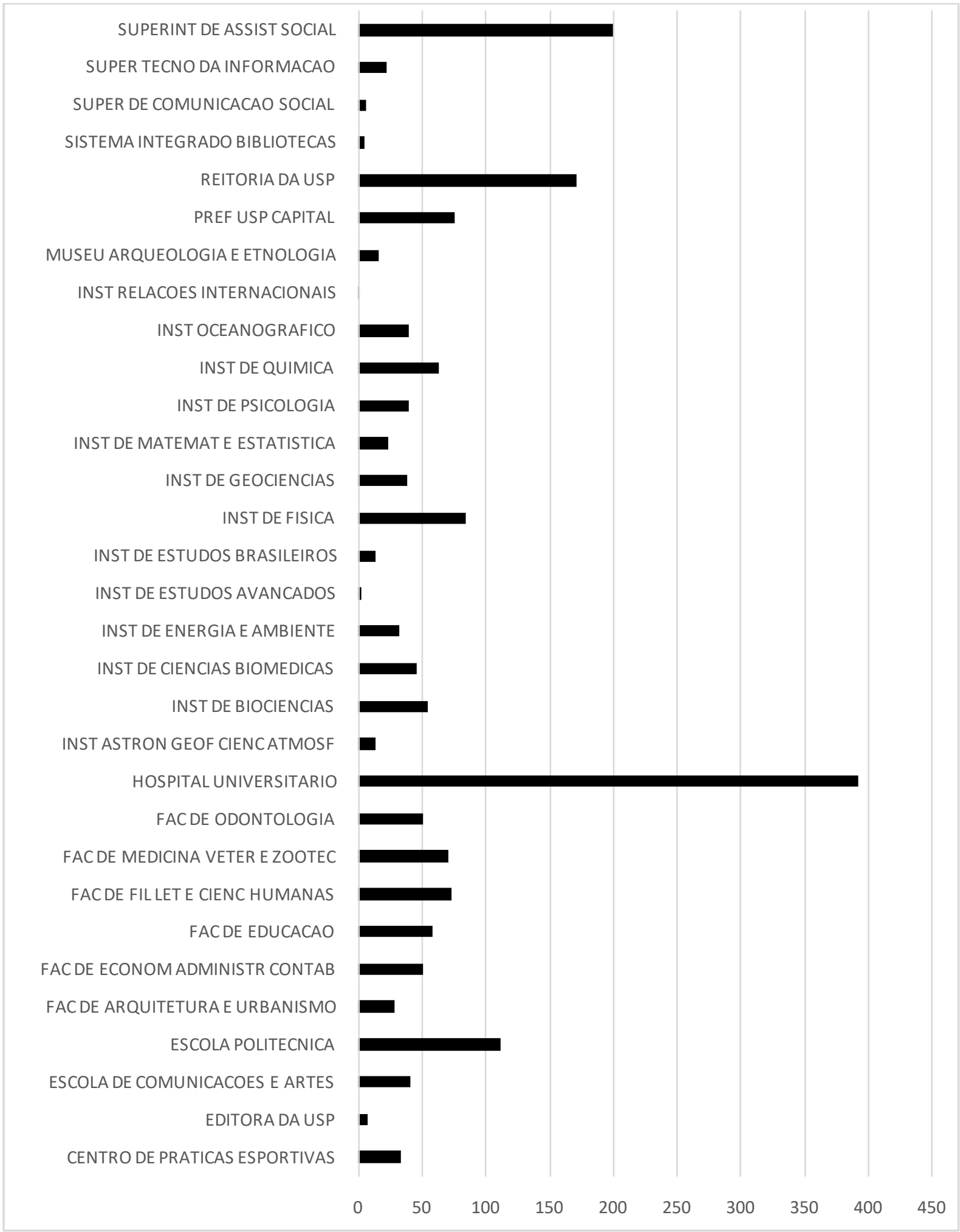

Fonte: Elaborado pelo autor (2018). 
Embora o mapa denuncie que o anel que representa o Hospital Universitário possui uma coloração mais intensa, é no gráfico que temos a comprovação desse fato. São quase 400 servidores negros - cerca de $20 \%$ do total de servidores negros/as - que estão nesse espaço do território. Como mostrado no mapa, temos como segundo espaço a Superintendência de Assuntos Sociais, com cerca de 200 pessoas, correspondendo a 10,70\% do total do corpo de servidores negros da USP e, por último, temos a Reitoria da USP, com um pouco mais de 150 pessoas, $9,19 \%$ do total.

A estrutura é pouco alterada quando o recorte de gênero é feito (Gráfico 9), respeitando os três espaços levantados nos dados gerais. Porém, com 66\%, o Hospital Universitário revela que não é somente um espaço onde a presença negra dos(as) trabalhadores(as) está massivamente aglomerada, mas é também onde se tem significativamente a presença do corpo negro feminino da USP. Na Superintendência de Assuntos Sociais, a presença feminina também supera a de homens negros, correspondendo a 53\% das trabalhadoras desse espaço, enquanto a Reitoria da USP é um espaço ligeiramente masculino em sua geografia dos corpos negros, com $34 \%$ de mulheres negras.

Gráfico 9-Servidoras negras da USP.

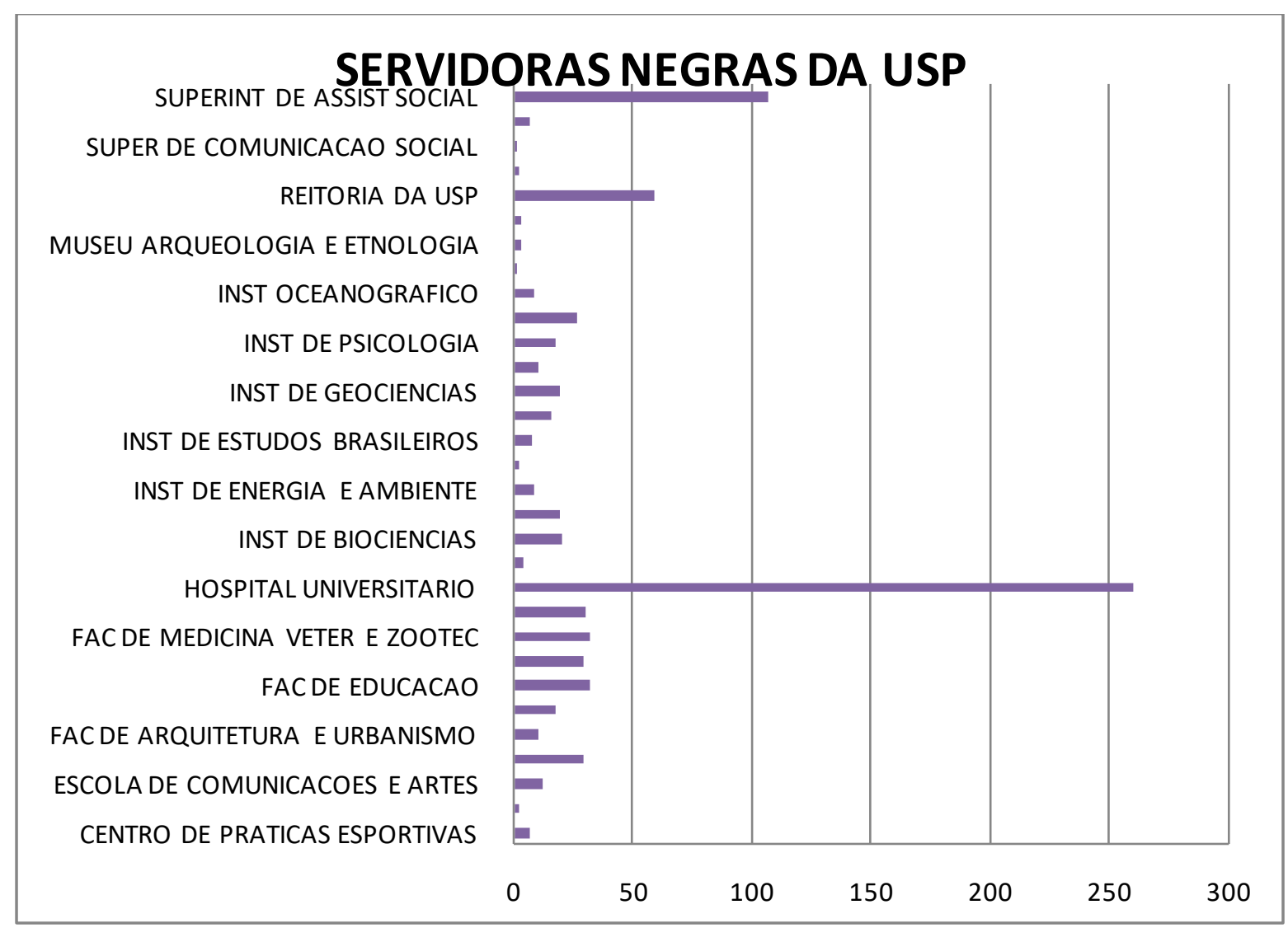

Fonte: Elaborado pelo autor (2018). 
Para além dos valores porcentuais, decidimos nos debruçar sobre os cargos para dialogar com esses três pontos quentes presentes no mapa. Lembramos que os dados que deram origem ao mapa e ao gráfico acima foram produtos da unificação de duas importantes categorias de servidores da USP: os docentes e os servidores técnico-administrativos, mas isso não significa que, a partir de uma observação mais próxima, não possamos analisar separadamente esses dois grupos.

A partir de uma apreciação da estrutura organizacional fornecida pelo Departamento de Recursos Humanos da USP, conseguimos ter uma percepção do que há de escuso nos dados referentes aos cargos para depois aprimorar a análise desses três principais espaços onde se tem uma maior presença de trabalhadores/as negras no território.

Segundo esse órgão, cargo/carreira é uma função/posição que uma determinada pessoa ocupa dentro da instituição. Pensando o corpo negro dos trabalhadores/as, sua trajetória profissional está diretamente ligada às particularidades da população negra de um país onde a democracia racial ainda é fictícia, condiciona de alguma forma as escolhas desses sujeitos, como já foi apontado no estudo sobre os graduandos.

As carreiras que são, segundo o artigo 2 da Resolução USP 5.912/2011, "agrupamentos das funções" serão, na ótica dos servidores técnico-administrativos, divididas em Básico, com sujeitos que apenas puderam cursar o ensino fundamental; técnico, em que as pessoas têm um grau de escolaridade que che ga ao ensino médio; e superior, com pessoas que já cursaram uma faculdade. Cada uma dessas carreiras será diretamente relacionada às devidas referências salariais ${ }^{33}$. Embora não pretendamos fazer uma análise financeira desse aspecto, buscamos compreender o vínculo das atribuições que essas funções têm com a causalidade na relação entre trajetória, formação educacional e ascensão social.

Ao considerar os docentes do campus da USP, temos uma outra estrutura organizacional de agrupamento das funções. A primeira diferença está na presença da subdivisão de duas categorias internas de docentes: aqueles ingressos pelo processo seletivo e os ingressos por concurso público. Os ingressos pelo processo seletivo são os docentes que possuem um tempo determinado de presença como professor na USP e que ingressaram a partir de editais publicados pelo Diário Oficial, havendo, nesse caso, presença de três categorias internas: a de Professor contratado I, em que o candidato possui no mínimo o curso

\footnotetext{
${ }^{33}$ É necessário pontuar que dentro de cada grupo de funções dos técnico-administrativos existe uma subdivisão que está relacionada ao movimento funcional da universidade e que é indicado pelas letras de cada carreira e um número indicativo do referencial salarial - B1, B2, ou mes mo T1, T2, consequentemente.
} 
de graduação; a de Professor contratado II - Assistente, cujo candidato possui no mínimo o título de Mestre; e o Professor contratado III - Professor Doutor, cujo candidato possui no mínimo o título de Doutor. Já para aqueles que entram no território da USP como professores concursados temos apenas duas subdivisões: a de professor Doutor, que precisa ter no mínimo o título de Doutor outorgado pela USP e com validade nacional, e professor Titular, portador do título de Livre-Docente.

Assim, ao nos voltarmos ao recorte étnico-racial dessa categoria, temos a distribuição dos cargos abaixo:

Gráfico 10 -Cargos dos servidores(as) negros(as) da USP - Butantã

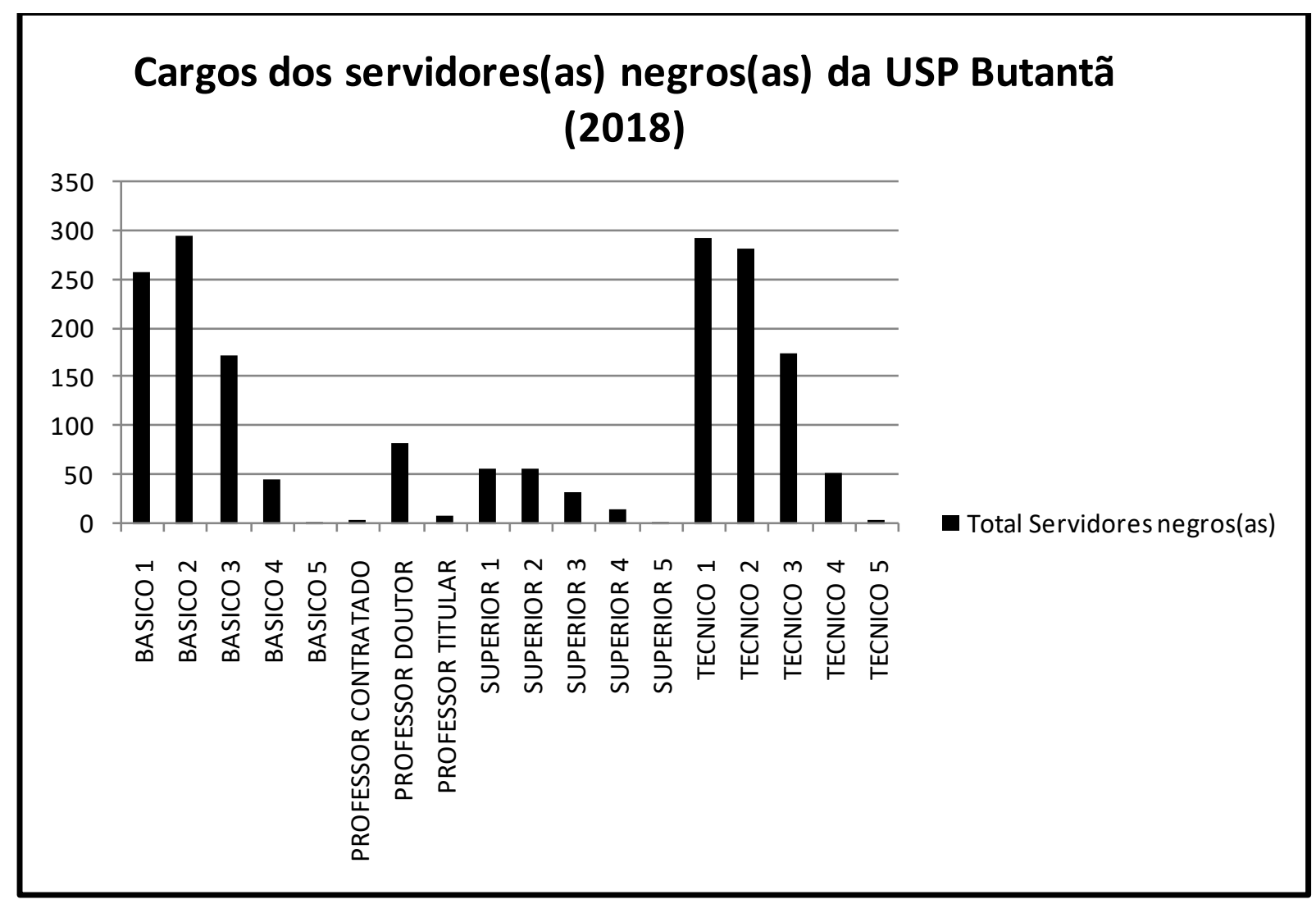

Fonte: Elaborado pelo autor (2018).

O gráfico evidencia a distribuição do contingente de servidores(as) negros(as) ao longo dos agrupamentos de funções da USP. Com já explicado, essas funções estão vinculadas não só às atribuições e responsabilidades de cada carreira, mas também às conquistas individuais das múltiplas trajetórias escolares de cada um desses sujeitos. O gráfico unifica tanto a categoria dos docentes como a dos técnico-administrativos da instituição para se ter um parâmetro geral da configuração dos cargos a partir da população 
negra. Assim, a primeira interpretação que o gráfico suscita é o acentuado crescimento das barras nos cargos de Básico e Técnico (que estão nas laterais) e uma queda no centro do gráfico, onde está a distribuição dos cargos de docentes. Essa primeira leitura nos faz compreender que, no território da USP, a população de trabalhadores(as) negros(as) está concentrada nos cargos de técnico-administrativo, sem se materializar nos espaços de sala de aula como professoras e professores universitários.

Delineando com mais cuidado e a partir do Plano de Classificação de Funções (PFC) os cargos da população negra da USP, vemos que as três mais acentuadas são as Básico 2, Técnico 1 e Técnico 3. Básico 2 está atribuído a funções como a dos/as auxiliares laboratórios, manutenção/obras e serviços gerais - e que se vinculam aos trabalhos ditos como "braçais" da universidade. Já o Técnico 2 e o Técnico 3 possuem uma escolaridade maior do que a encontrada no Básico 2, tendo funções na USP como a de agentes de vigilâncias e técnicos de enfermagem, laboratório, manutenção/obras, assuntos administrativos.

Mesmo em menores proporções no gráfico, temos que, no grupo dos docentes, existe uma prevalência de professores doutores em relação a outras categorias de docentes, como a de professores contratados e titulares. Já no grupo dos que possuem nível Superior, que são os técnicos-administrativos que têm diploma universitário, temos um decréscimo a cada movimento funcional - tendo o Superior 1 e 2 uma paridade, mas que decai no Superior 3 e no Superior 4. Esse fato em especial mostra que, quanto maior o nível de exigência educacional, menor a presença negra no grupo dos servidores técnico-administrativos.

Pensando nas mulheres negras que trabalham na USP também podemos ter uma mudança na estrutura dos cargos ocupados pela população negra, como mostra o gráfico abaixo: 
Gráfico 11 -Cargo das mulheres negras na USP - Butantã

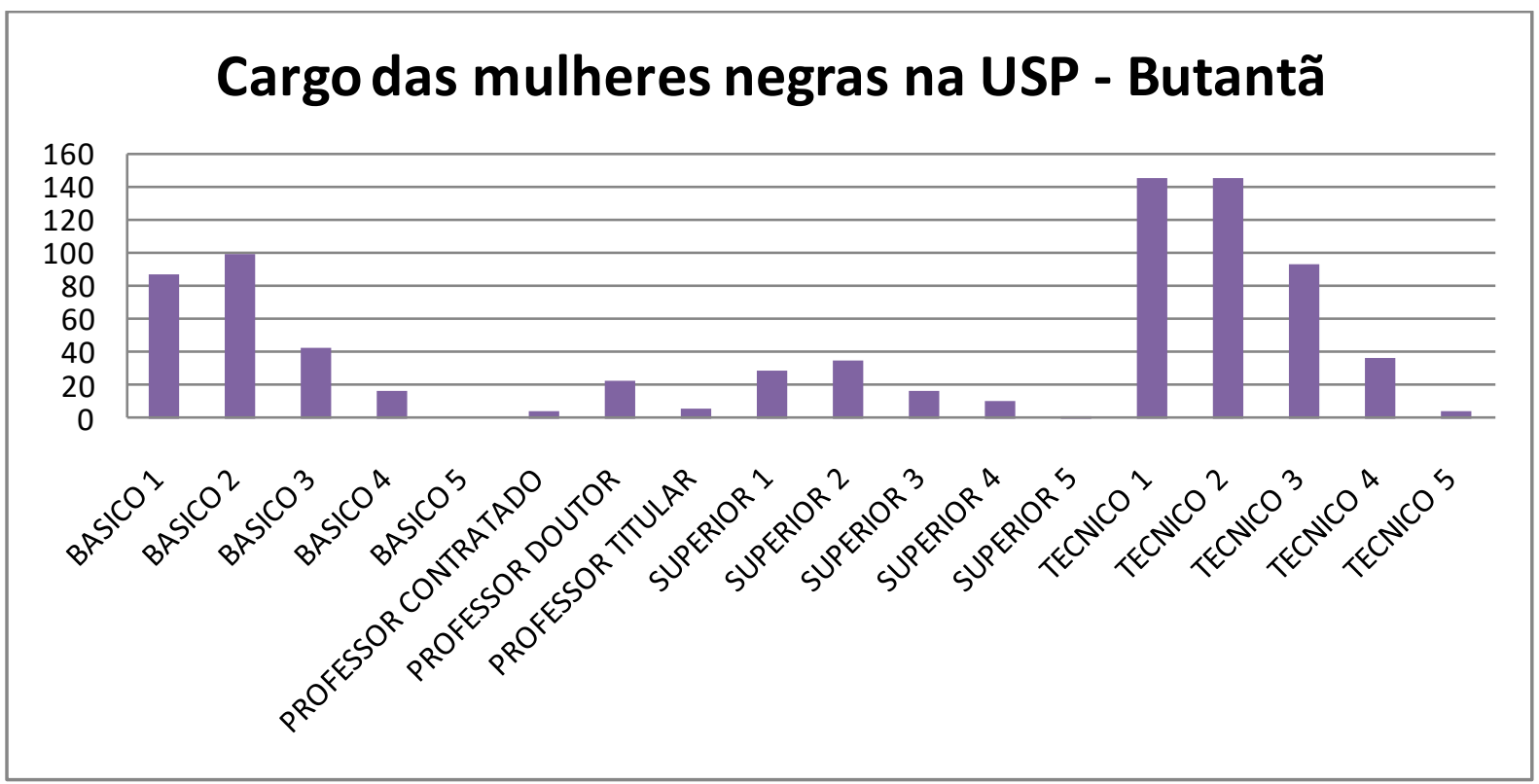

Fonte: Elaborado pelo autor (2018).

Seguindo a mesma lógica de análise, mas agora com o recorte de gênero/raça, temos uma reclassificação entre as três categorias de destaque no gráfico e que aponta uma maior concentração nos cargos de Técnico 1, Técnico 2 e Básico 2. Esse deslocamento criado pela leitura de gênero/raça faz com que entendamos, no caso das técnico-administrativas negras, que elas estão ligeiramente à frente no que diz respeito ao movimento funcional dos técnicos, havendo uma troca em relação à realidade existente no gráfico geral, em que o Básico 1 assume a posição inicial. Esse deslocamento pode ser explicado pela maior escolaridade, em níveis porcentuais, das mulheres negras em comparação aos homens negros (OSORIO, 2006).

Retornando para a questão dos docentes, percebe-se que, nesse grupo, no que diz respeito à população negra, esta ainda não está - tanto no gráfico geral como no gráfico com recorte de gênero - se territorializando da mesma forma como ocorre com os servidores técnico-administrativos. Apesar de termos no gráfico geral dos(as) servidores(as) negros(as) um realce na coluna de professores doutores, esta se dilui quando comparamos com a realidade do grupo étnico-racial que prevalece no campus, como mostra o gráfico abaixo: 
Gráfico 12 -Cargo de servidores negros e de servidores brancos

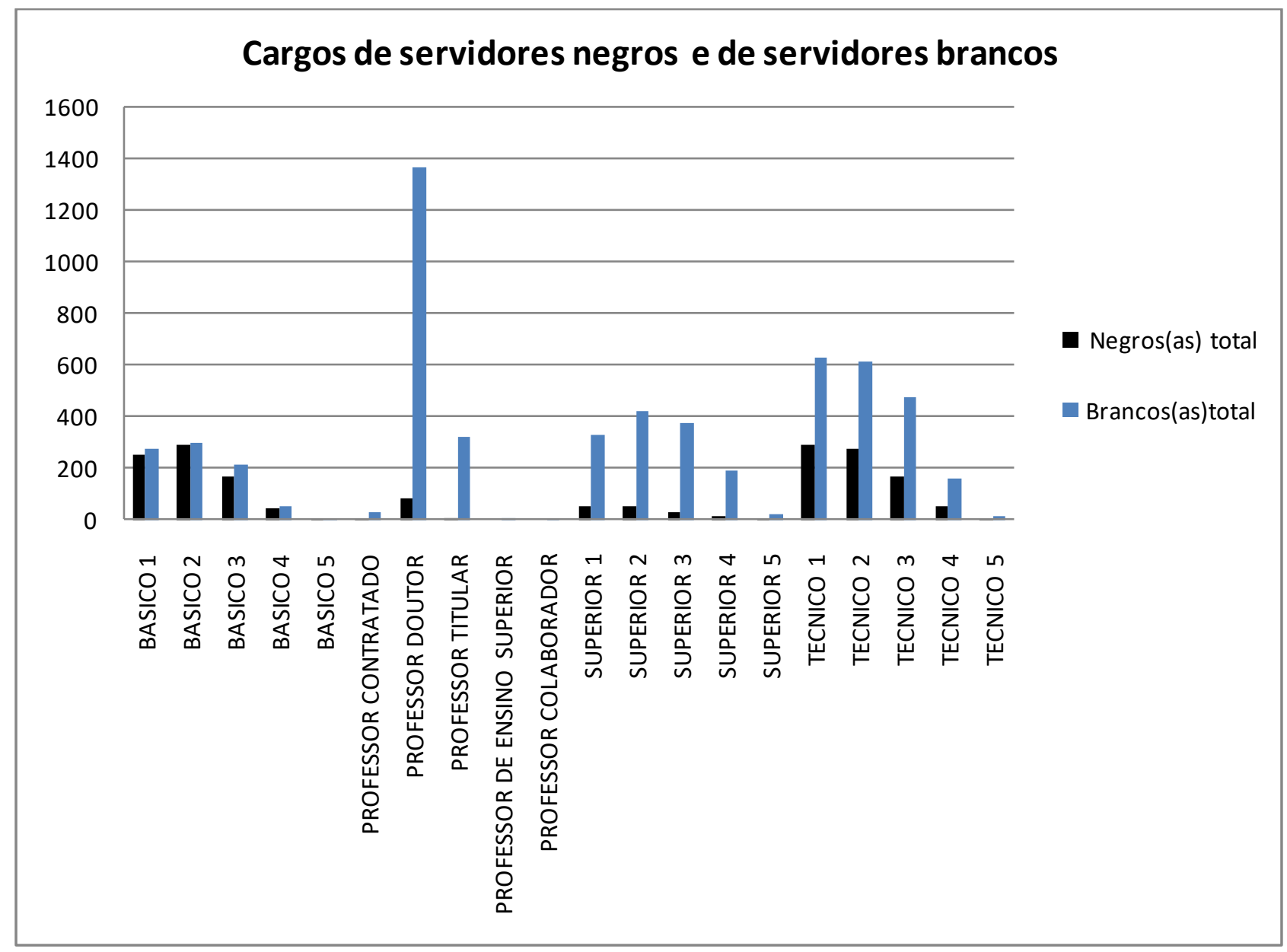

Fonte: Elaborado pelo autor (2018).

Representando quase $70 \%$ dos trabalhadores/as do território universitário, os servidores brancos se destacam praticamente em todos os cargos da USP. Essa prevalência resulta no que pontuamos como diluição da presença negra na grande parte dos cargos que exigem maior escolaridade (professor, supervisor e técnico) e em uma quase horizontalidade - digamos aproximação - nos cargos de menor exigência escolar (Básico).

No caso dos professores doutores ${ }^{34}$ que, em um primeiro olhar, trazem para o debate sobre a população negra uma impressão de avanço quanto à presença de professores negros doutores, o gráfico comparativo acima fornece uma outra percepção dessa realidade. Esta demonstra que, em relação aos professores doutores brancos, temos que esses são quase 17

\footnotetext{
${ }^{34}$ É impor salientar que essas subdivisões nada mais são do que hierarquias dentro da categoria dos docentes da USP, como pontua Silva (2015, p. 187), em que ser professor Doutor "constitui o primeiro degrau da carreira docente da USP, professor titular o nível ma is elevado".
} 
vezes maiores do que os professores negros de mesmo cargo e, em um parâmetro geral, das diferentes categorias de professores, observamos que apenas $\mathbf{4 \%}$ do professorado da USP Butantã ${ }^{35}$ é negro.

Gráfico 13- Professores(as) negros(as) da USP Butantã.

Professores/as Negros/as da USP Butantã

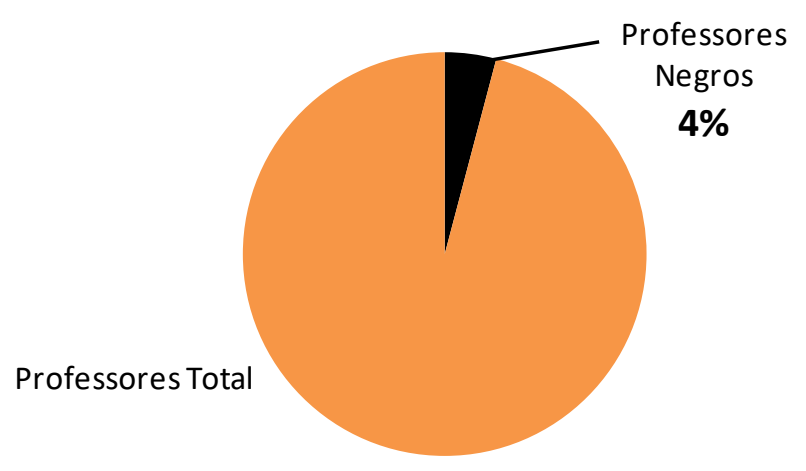

Fonte: Elaborado pelo autor (2018).

Essa análise sobre os cargos docentes e técnico-administrativos também nos ampara no estudo sobre os sujeitos negros que estão ocupando os três pontos quentes do território (Gráfico 14), onde existe uma maior densidade de servidores negros da USP: o Hospital Universitário, a Superintendência de Assuntos Sociais e a Reitoria da USP. No caso do Hospital Universitário, onde há uma preponderância de mulheres negras, temos como principal cargo o Técnico 1, marcado pela presença da função ativa da técnica em Enfermagem. Essa profissão justificaria a combinação gênero/raça na relevância da territorialização do corpo de trabalhadoras negras na realidade do território universitário, sendo também um sintoma, já analisado em inúmeras pesquisas, sobre a ascensão negra ${ }^{36} \mathrm{e}$ as escolhas profissionais. ${ }^{37}$

\footnotetext{
${ }^{35}$ Ainda sobre os docentes, notamos que, ao inserirmos os dados dos professores brancos, surgem, dentro do cargo de professores, duas categorias inexistentes nos dados de docentes negros. Estamos falando dos professores colaboradores e professores de ensino superior, que provavelmente são cargos extintos, pois não há informações sobre eles nos arquivos informados no site oficial do Departamento de Recursos Humanos.

${ }^{36}$ Dados do Conselho Federal de Enfermagem (COFEN) têm demonstrado a predominância de mu lheres ne gras na Enfermagem em alguns Estados do Brasil. No Mato Grosso, por exemplo, a Enfermagem é negra e feminina, chegando a $85 \%$ de mulheres e $67 \%$ de negros.

37 Em seu trabalho "A história social da enfermagem brasileira afrodescendente e formação profissional pós 1930”, o pesquisador Paulo Fernando de Souza Campos (2012) nos dá um caminho para entender um pouco mais essa concentração de mulheres negras no campo da Enfermagem. Segundo ele, a enfermagem em São Paulo, na década de 1930, "reconfigurou não somente a formação profissional, mas também a identidade
} 
Gráfico 14 -Cargos dos três pontos quentes do território da USP Butantã.

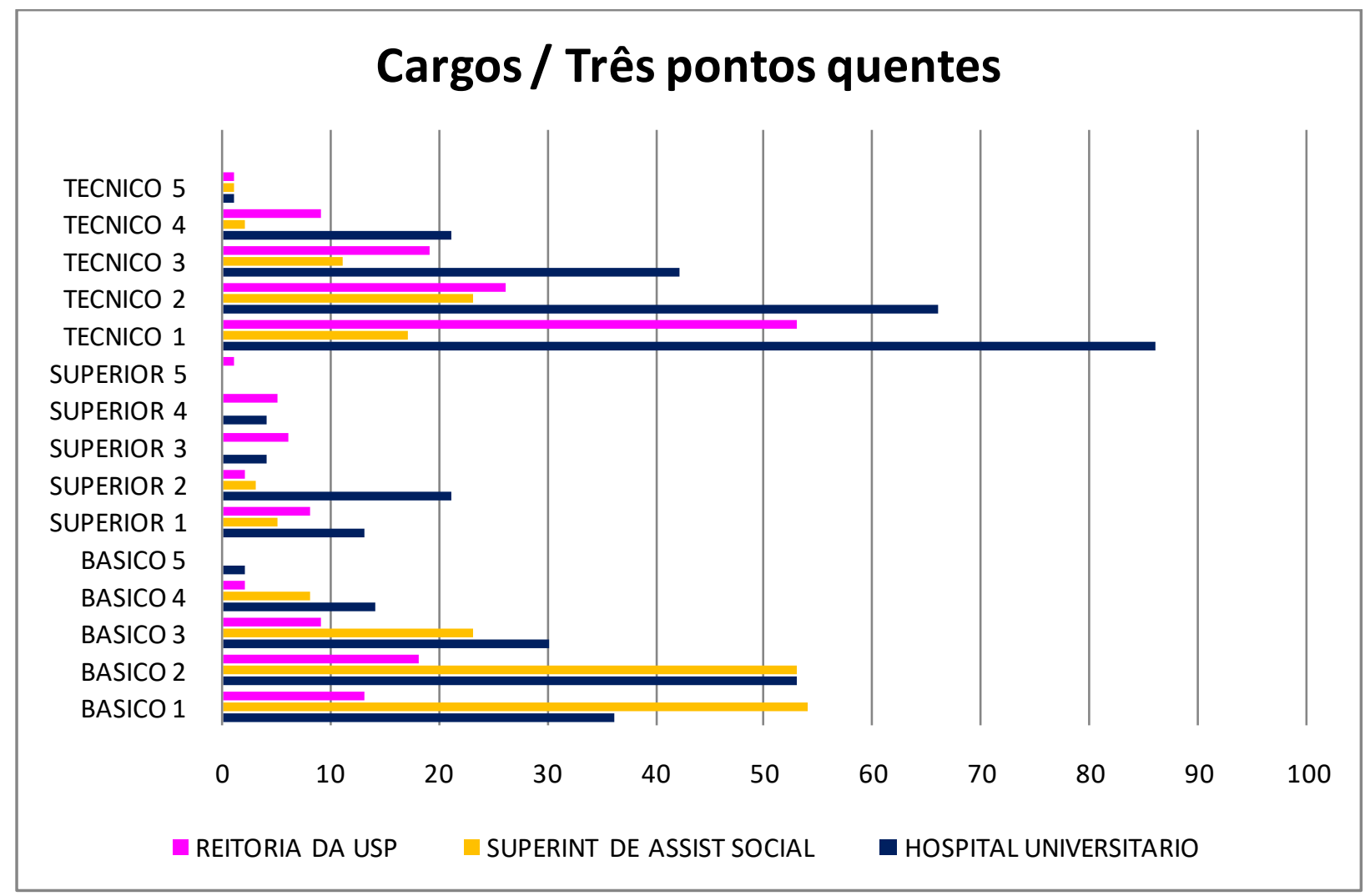

Fonte: Elaborado pelo autor (2018).

No caso da Superintendência de Assuntos Sociais (SAS), percebe-se que, nesses espaços, o gráfico é inchado principalmente nos cargos Básico 1 e Básico 2, refletindo-se em uma geografia do corpo que evidencia a relação da presença de trabalhadores(as) negros(as) em funções e ações determinadas no campus. Estamos falando aqui de um espaço no território onde o trabalho é, como já pontuamos, "braçal", reproduzindo uma violência simbólica (GONZALES, 1984) que associa o corpo negro a tarefas e posições que estão em patamares mais baixos da hierarquia social. Assim, o movimento desses sujeitos no território está diretamente vinculado aos cargos e funções da geografia da SAS, ou seja, grande parte desses trabalhadores negros está se territorializando na cozinha do restaurante universitário, nas portarias das moradias estudantis ou até mesmo na infraestrutura e na manutenção do campus.

No caso da Reitoria, que representa o último ponto quente do mapa, os cargos, diferentemente da SAS, se concentram principalmente em técnicos (Técnico 1, Técnico 2 e

profissional da enfermagem do Brasil, pois incluiu disciplinas que não existiam no antigo modelo, como enfermagem, psiquiatria e moléstia tropicais, assim como possibilitou a reintegração de homens e mulheres negras na enfermagem brasileira" (Ibid., 2012, p. 175). 
Técnico 3), em uma decrescente no movimento funcional, conforme o aumento da necessidade de escolaridade. Dessa forma, é muito possível que o corpo negro aqui esteja materializado no território como agentes de vigilância, técnicos de segurança do trabalho ou de manutenção e obras, retomando novamente as funções desses sujeitos e a relação que eles possuem dentro do território.

A configuração do corpo negro na mão-de-obra da USP Butantã, trazida em valores quantitativos, revela informações importantes acerca da população negra que usa e ocupa o território universitário e cria uma "miragem" (SILVA, 2015) na escala de observação. Esse descompasso foi acertado ao trazermos para o campo de visão, por meio da averiguação da totalidade, comparações entre a população negra e o grupo étnico-racial prevalente dentro do território da USP, o que permitiu, para a proposta desta parte do trabalho, uma discussão séria sobre esse corpo e as desigualdades territoriais que marcam as diversas funções da USP.

No caso dos docentes, a pesquisadora Silva (2015), em seu doutorado sobre a configuração racial do corpo docente da USP, afirma o seguinte sobre a desigualdade racial nesse âmbito:

A sub-representação do negro/s no corpo docente tende a permanecer historicamente, indicando uma clara racialização da (im)possibilidade de ascensão de negros/as na carreiras docentes da USP, uma vez que esse grupo, conforme indica, tendeu a diminuir proporcionalmente à medida que se tem avanços nos degraus das categorias docentes. (Ibid., p. 192)

Essa (im)posssibilidade de ascensão também está retratada nos dados referentes às carreiras dos servidores técnico-administrativos do território da USP, em que as ações de grande parte desses trabalhadores tendem a respeitar a lógica cristalizada da linha de cor "que marca as distâncias históricas entre brancos e negros no ensino superior" (Ibid., p. 169). No caso dos estudantes de graduação percebemos que, mesmo com os avanços, os cursos que possuem uma posição social de poder ainda têm uma prevalência do grupo branco, majoritário na universidade.

A importância desse levantamento é parcial, pois, para além dos valores percentuais, dos gráficos e dos mapas, as relações entre os sujeitos produzem e são produtos de inúmeros movimentos dentro desse complexo sistema de cargos e cursos, que dialogam com as realidades individuais dos sujeitos. Por isso, é necessário nos voltarmos para a e scuta dessas individualidades negras que grafam o cotidiano desse território e preenchem o entendimento dos fatores que ressoam de fora para dentro das fronteiras do corpo negro universitário. 


\section{CAPÍTULO 2 - A individualidade da comunidade negra}

Além das delimitações físicas, um território possui em seu conteúdo uma gama de grafias que dão significado para sua forma. Essas grafias podem ser caracterizadas por elementos imateriais, como as histórias que são construídas, paralelamente com a formação do território, pelos diversos sujeitos que o ocupam e dão valor a suas geografias. No caso do campus Butantã da Universidade de São Paulo, essas grafias podem ser instrumentos que evidenciam trajetórias individuais da população negra no interior da Cidade Universitária e fornecem uma perceptiva distinta de outros grupos. A partir dos espaços ocupados na USP, temos, então, narrativas necessárias para compreender não apenas as individualidades dos sujeitos negros desse território, mas também o cotidiano ${ }^{38}$ de um grupo que possui vivências e caminhadas fundamentais para o entendimento dos conflitos e das solidariedades que dão movimento para a geografia da universidade.

Nos voltamos, assim, para o que a escritora e pesquisadora Conceição Evaristo (2009; 2017) descreve como "escrevivências", quando a escrita surge de um cotidiano em que as lembranças e vivências de sujeitos negros se tornam um método para o entendimento de toda uma experiência coletiva vivida pela população negra no Brasil. Esse acúmulo de experiências consegue combinar os relatos individuais com uma totalidade que marca as diversas formas de práticas sociais e raciais que envolvem a vida desses personagens e suas múltiplas relações dentro da universidade.

$\mathrm{Na}$ USP, os sujeitos negros ocupam diversas funções na universidade, como técnicos que administram toda uma logística de documentos e formalizam processos acadêmicos ou como professores que estão em laboratórios e dominam todo um alfabeto científico que certifica o status quo da instituição. Ao representarem em especial essa categoria de trabalho na universidade, atuando como docentes, esses sujeitos também contrariam uma lógica estatística que rege um país outrora colonial e escravocrata, mas que ainda naturaliza a ausência de professores e estudantes negros nas universidades públicas brasileiras (SILVA, 2015).

Esses personagens também estão presentes na figura de alunos(as) da USP de diferentes áreas da graduação, que apresentam explanações sobre suas trajetórias que se

\footnotetext{
38 Aqui nos apegamos à ideia de Santos(1996), que compreende o cotidiano como herança do passado e projeto para o futuro, para pensarmos a relação tempo-espaço e o negro. Desse modo, entendemos que o cotidiano para esses sujeitos é fruto de um processo histórico que transborda na USP, abrangendo toda uma esfera que envolve a estrutura de formação do negro na sociedade brasileira.
} 
alinham a um lastro comum de experiências quanto à relação que têm com o território do campus Butantã. Ao mesmo tempo, é relevante pontuar que essas experiênciasestão ligadas a padrões diferenciados no espaço (SIQUEIRA, 2017), ou seja, a partir de uma sobreposição do racismo e da memória, esses estudantes são marcados por inúmeras situações de violências dentro da universidade que criam barreiras simbólicas que margeiam esses sujeitos e suas subjetividades dentro e fora da sala de aula.

A subjetividade desses indivíduos, seja como trabalhadores, seja como estudantes da USP,torna-se também uma ferramenta de análise dupla, já que pode ser considerada para entender não apenas o grau de consciência dos sujeitos em si, mas também a consciência que estes possuem de seus pares, ou seja, suas alteridades. Essa análise duplaé o que Santos (1996) nomeia de "transindividualidade", autorizando, até determinado ponto, as dificuldades no interior do território e a relação dos indivíduos como parte da condição da produção da sociedade. Sendo assim, em uma sociedade desigual como a brasileira, tem-se que, para a população negra, podem existir situações que são embasadas pela clivagem racial mesmo estando em um território marcado por um cotidiano acadêmico.

As entrevistas, nesse sentido, registraram a rotina desses diversos personagens que fazem parte de uma territorialidade negra universitária. Com suas narrativas, eles demonstraram a inexistência de uma possível neutralidade nas relações humanas, principalmente no que diz respeito às condições diárias que articulam o indivíduo ao território e o território às práticas funcionais desses sujeitos negros da USP.

Desse modo, o território e suas narrativas internas se complementam simbolicamente, oferecendo uma rica possibilidade de entender a universidade na perspectiva desses indivíduos que, com suas territorialidades, legitimam a leitura das ações - e contradições que existem no território(HASBAERT,2016) sob o olhar da população negra.

A forma como servidores e estudantes se utilizam do espaço e se organizam nele (SACK,1986) também circunscreve práticas que,embora diferentes no que se refere às suas funções na universidade, são semelhantes do ponto de vista de referência a uma linha temática que costura sua corporalidade negra, marcada pelo racismo à moda brasileira (MUNANGA,1999;SILVA, 1995). Esse corpo passa por situações dentro da universidade que constituem uma consciência individual do que é ser negro na USP e, ao mesmo tempo, processam uma solidariedade coletivaque evidencia narrativas críticas que denunciam as problemáticas comuns a esses sujeitos na sociedade brasileira. 


\subsection{Apresentando as vozes}

Como já esclarecido na introdução desse trabalho, todos os entrevistados participaram desta pesquisa de forma voluntária, depositando confiança e tendo vontade de contribuir com a elaboração do entendimento do que é a Universidade de São Paulo do ponto de vista da população negra. São sujeitos que, com diferentes temporalidades, sabem da importância de dar voz para o que compreendem sobre o território da USP Butantã e as suas relações humanas.

Como metodologia e para melhor organização do que aqui pretendemos, o nome de cada um dos personagens será substituído por um nome de origem africana. Cada um dos nomes foi escolhido a partir da personalidade apresentada e entendida pelo pesquisador em cada encontro.No total foram dez encontros, em espaços diferentes da universidade.

O primeiro encontro foi com a servidora Sekai, nome que significa "sorriso". A escolha desse nome se deu pelo fato de que, durante a entrevista, as respostas compartilhadas pela servidora eram marcadas por um sorriso no rosto, um forte sorriso de uma moradora do Rio Pequeno que trouxe para nós importantes revelações sobre como é estar ocupando há 16 anos um dos prédios da FFLCH.

O segundo entrevistado foi o Fela, nome que significa "guerreiro".O servidor técnicoadministrativo que há 31 anos trabalha dentro do campus apresentou na entrevista um relato de suas atividade se da sua persistência contra as adversidades vivenciadas dentro do campus Butantã.

A terceira servidora que contribuiu nas entrevistas foi a Nyota, cujo nome significa "guerreira". Um exemplo de luta e moradora da zona oeste de São Paulo, a servidora trabalha há 28 anos no Instituto de Ciências Biomédicas (ICB), sendo uma das grandes facilitadoras das práticas científicas da universidade.

Karassi foi a quarta a participar das entrevistas. Seu nome significa vida e sabedoria, escolhido por ser uma representação fiel do que sentimos na fala dessa servidora que trabalhou por 28 anos na creche central da universidade.

O quinto entrevistado foi Lutalo, servidor da Faculdade de Educação. Seu nome significa "guerreiro" e foi escolhido pelo vínculo que o servidor possui com os movimentos sindicais da universidade e pela sua trajetória como morador do Rio Pequeno. 
O Yerodin, por sua vez. foi nosso primeiro estudante entrevistado. Ele cursa Química e é morador do CRUSP. Em sua entrevista percebemos o quanto o estudo envolve não somente a relação que possui com a universidade, mas também o que marcou toda sua trajetória de vida.Por is so, escolhemos esse nome para batizá-lo, já que significa "estudioso".

Nassor foi nosso primeiro professor entrevistado. Ele foi escolhido por ser um professor que ocupa outro espaço de sala de aula dentro da USP: o da Escola de Aplicação. A cada testemunho do professor, ele foi se revelando como um vitorioso, o que nos fez escolher o nome Nassor, que significa "vitorioso".

Baduc, estudante de História, foi nossa oitava entrevistada. Ela trouxe uma fala forte e poderosa sobre sua presença no território da USP, nos levando a nos questionar a respeito de como uma estudante pôde ter vivenciado tantas história sem cinco anos de USP. Nesse sentido, escolhemos o nome Baduc por significar "poderosa", palavra que define bem a estudante.

A nona entrevista foi com uma professora negra da FFLCH, a Akilah, nome africano que carrega a ideia de inteligência e razão. A professora, que possui 20 anos como educadora, ocupou antesa função de aluna e, em seguida, a de técnico-administrativo da universidade. Toda essa carga de vivências foi fundamental para que ela expressasse importantes palavras sobre o que é ser uma professora negra na USP.

A décima e última entrevista foi com uma aluna de Arquitetura e Urbanismo chamada Faizah. Com apenas dois anos de USP, ela viveu uma carga de situações que a colocaram como "vitoriosa", significado do nome escolhido para ela.

Essas dez vidas e dez vozes serão organizadas e justapostas ao longo deste capítulo para que tenhamos uma compreensão da totalidade das relações que criam territorialidades dentro do campus Butantã. Essas relações que envolvem o grupo entrevistado abarcaram situações diárias nos espaços ocupados, revelando trajetórias e funções que os vinculam ao território universitário. Além disso, a leitura dessas narrativas simboliza a quebra de uma normativa acadêmica que desqualifica o conhecimento produzido pelas trajetórias desses sujeitos negros que têm, muitas vezes, suas vozes silenciadas (KILOMBA,2010). É hora, portanto, de escutá-las, permitindo ao leitor elucidar fatos e fardos que caracterizam um(a) trabalhador(a) e um(a) aluno(a) negro(a) da USP e trazendo à tona temas e paradigmas que têm sido analisados para o estudo das relações raciais brasileiras. 
A organização de cada umas dessas narrativas será feita em três subcapítulo, nos quais aproximaremos as diversas experiências negras existentes na USP. O primeiro desses subcapítulo tem como objetivo explicar os primeiros contatos que esses sujeitos tiveram com o território do campus Butantã e os caminhos que fizeram para se tornarem servidores(as) e estudantes em uma das maiores universidade do Brasil. O segundo subcapítulo dessa etapa do trabalho busca compreender a consciência que esses sujeitos possuem sobre ser negro(a) dentro da USP, entendendo também que essa consciência transborda as fronteiras universitárias. Fechamos esse momento sobre as vozes desses personagens negros com um subcapítulo que aborda o racismo e a relação dessa ideologia com os indivíduos da universidade, pois, quando lidamos com vidas negras, "não existem histórias pessoais ou reclamações íntimas, mas consequências do racismo" (KILOMBA, 2010, p.48). Assim, cabe ter um olhar sobre o quanto esse construtor social que é o racismo condiciona a territorialidade desses indivíduos pelo campus.

Convocamos aqui não só uma epistemologia que inclua a subjetividade (KILOMBA, 2010), mas também uma espacialidade dessas narrativas para o entendimento das territorialidades que escrevem na geografia da Universidade de São Paulo um território que não é neutro sob a ótica das relações entre os indivíduos.

\subsection{A trajetória diferenciada e os caminhos que se entrecruzam}

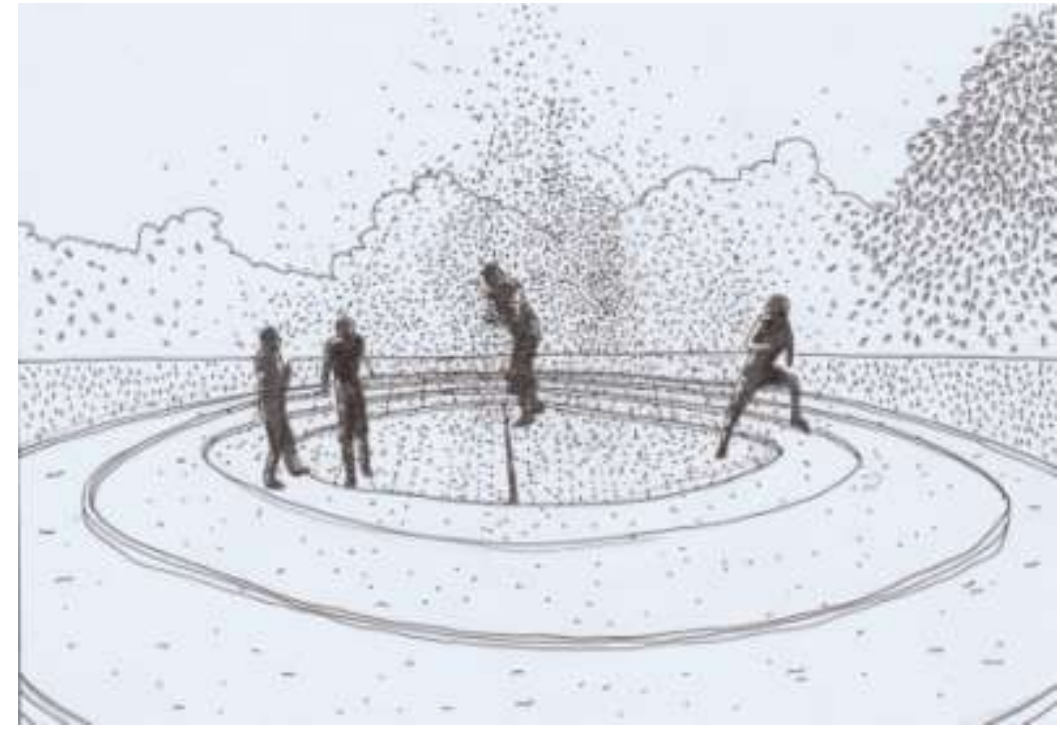

Figura 5 - Gotas negras

Créditos: Isadora Almeida Simões ${ }^{39}(2019)$

\footnotetext{
39 Isadora Almeida Simões, além de artista visual é Geógrafa formada pela USP. A partir da sua perspectiva enquanto pesquisadora e artista conseguiram minuciosamente materializar as entrevista em forma de arte.
} 
Minha primeira vez acho que eu tinha doze para treze anos, era uma mulecota. Tava sendo construído esse hospital universitário. A gente vinha muito brincar, né? Porque a gente morava aqui na comunidade na época, então a gente vinha brincar, fazia o passeio todo aqui dentro, tinha até lá embaixo, ali na Poli, o chafariz, que era nossa prainha[risadas]. Era muito bom. Quando criança a gente vinha se divertir, então era assim a nossa primeira vista aqui dentro.A gente começou a conhecer a universidade assim: como um espaço de diversão.

Iniciamos nossa escuta com a fala da servidora Sekai. Vimos no início do trabalho que, na perspectiva tradicional, o território é caracterizado como um espaço delimitado por uma fronteira; porém, quando nos debruçamos sobre o seu interior, nos deparamos com um conteúdo rico em possibilidades de análise quanto à sua geografia. No caso de uma universidade, materialmente falando, as construções como prédios, ruas e pontes acarretam fluxos e movimentos espaciais para o território, mas, no caso da servidora Sekai, seu olhar enquanto "mulecota" ofertou um outro significado para a USP, que expande o sentido de universidade, agregando ao espaço uma dimensão de lazer.

O caso da Sekai se emparelha com outras histórias de famílias negras que estão no entorno da universidade (ROCHA, 2016), cujo primeiro contato com o campus, quando o seu corpo negro inicia uma relação com a USP, não se dá na condição de estudante ou de servidor. A aproximação inicial, para alguns entrevistados que moravam em bairros ao redor da universidade, os levava a ter aquele espaço como um território para a manutenção das relações de afetividades, como foi o caso da servidora Karassi:

Olha, essa pergunta é interessante porque eu nasci e me criei aqui, ao redor do campus USP. Então eu vinha brincar aqui na Universidade de São Paulo. Ela era praticamente meu quintal. A gente vinha brincar, escorregar no barranco, com folha de bananeira, catava pitanga, as frutinhas que tem por aí; fruta orvalho - tem muita gente que nem conhece essa fruta -, uma fruta amarelinha, também a uva japonesa, a goiaba, a ameixa. Depois de um tempo eu passei a frequentar aqui com o meu namorado. A gente trazia uma vitrolinha e ficava curtindo um som. Assim, isso aqui é o palco da minha infânc ia praticamente. Foi muito emocionante trabalhar aqui.

"Ele", o território da USP-Butantã, se apresentava para Karassi quase como um grande pomar que sacia as vontades da servidora que, ainda jovem, conseguia catalogar a diversidade botânica existente dentro da universidade. É interessante pensar a universidade nesse ponto de vista produtivo (alimentar), pois se contrapõe à visão que se tem da relação entre sociedade e natureza e que estamos normalizando em uma grande cidade como São Paulo. Essa relação, muitas vezes tratada de forma separada em uma sociedade moderna 
(GONÇALVES, 2006), se fazia indissociável aos olhos de Karassi em sua infância, sobretudo no que diz respeito à sua memória afetiva com a instituição que, para ela, se transformava em um grande "quintal". Os quintais, que também podem representar a construção e a sobrevivência de saberes tradicionais (GOMES, 2009), possuem para a população negra residente da cidade uma área de "encontro, festas, ritua is..." (GOMES, 2009, p.144).No caso da Karassi, a universidade, a USP, se remodela como um espaço de namoro na sua juventude.

A memória que faz referência ao território da USP como um quintal também surge na fala de Fela:

Como trabalhador eu sou criado aqui na região, sou cria aqui do Butantã. Cheguei para morar no Butantã, próximo do Rio Pequeno, justamente no fundo do vale onde está o CEU Butantã. Cheguei para morar lá no dia do meu aniversário de 3 anos, no dia 9 de dezembro de 63. Então me criei aqui, ou seja, é a USP uma espécie de quintal da gente. Vinha aqui quando adolescente e tal e,nessa época, nessa coisa de território, você tinha seu lugar, a sua vila lá, mas a gente saía depois de adolescente para andar de bicic leta, então esse território se expande. A USP era um lugar que a gente vinha brincar, jogar bola, andar de bicicleta. Sou de uma época que tinha amigos que moravam aqui dentro da USP. Por exemplo, na parte alta, ali onde está o ICB, onde está o HU, onde tá o ponto lá em cima... Essas unidades migraram lá pra cima porque antes elas ficavam nos barracões onde tinha espaço onde tá a FEA ali. Os barracões dos pontos estão lá pra cima agora, mas eles ficavam tudo aqui embaixo, em frente da Psicologia.Nessa época, na parte alta lá, tinha muita gente que morava aí, servidores da USP que moravam ali, e lembro que vinha em casa um amigo que morava ali, parte da USP.

O mais interessante do relato do servidor é que sua história revela não só os espaços afetivos presentes na sua infância, mas também como esses espaços foram transformados e, no ano de 2018, quando foi feita essa entrevista, já não existiam mais. A USP era a extensão do território do servidor que, ainda pequeno, já ocupava partes da universidade, tratadas como um grande parque. Karassi jogava bola, andava de bicicleta, visitava amigos que viviam dentro da universidade, ou seja, a USP era uma extensão natural de circulação territorial, onde as fronteiras eram mais fluidas e as relações com a comunidade mais comuns.

Outro caso bem semelhante de convivência inicial com a universidade é a do servidor Lutalo: 


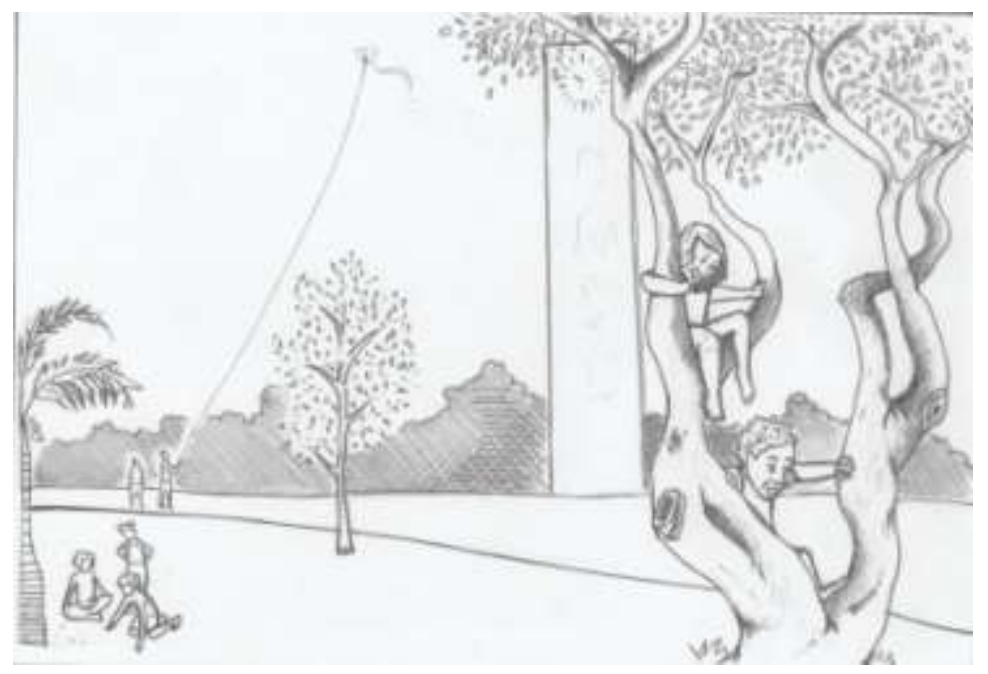

Figura 6 - Universidade dos afetos.

Créditos: Isadora Almeida Simões (2019)

Eu era ainda menino, cara.Eu lembro que na universidade tinha festival de pipa. Meu pai me trazia, porque meu pai sempre morou na região da Vila Dalva. Ele já sabia e, além disso, ainda tem os meus tios que trabalham aqui. Então, querendo ou não, tinha um pouquinho mais de informação do que era a universidade. Era muito pequeno, cara, não lembro bem qual que era a idade, mas era por volta dos 10 anos.

A realização de eventos abertos para a comunidade externa criou, para o servidor, um vínculo afetivo com as primeiras lembranças que teve com a universidade. O envolvimento que ele tinha com o pai e com o pipa no interior da instituição forma, nas palavras dele, uma fotografia desse momento em que a USP Butantã possuía uma fluidez maior entre tudo e todos que estão em seu entorno. Porém, Lutalo também traz um dado importante, que é a presença de familiares ${ }^{40}$ trabalhando como servidores no território, uma ponte para a orientação sobre o que era a universidade.

Nem sempre a lembrança desse primeiro contato com o campus se resume a um único momento. Para Akilah, por exemplo, ingressar no território da USP pela primeira vez se divide em dois momentos. Segundo a professora:

Não dá para falar de um só. Eu estava no terceiro ano colegial já, e eu gostava muito de passear na USP. Eu ia ler na USP. Eu ia ler nos gramados da USP. Eu já sabia que lá era a Universidade de São Paulo; que o campus era aberto para a comunidade. De sábado e de domingo eu ia ler no campus da USP. Eu pensava: será que um dia eu piso aqui como aluna?

\footnotetext{
${ }^{40}$ Veremos logo em seguida que este também foi um importante fato para que Lutalo ingress as se como servidor na universidade.
} 
Aí a outra vez que eu pisei foi para fazer a matrícula,e imediatamente eu recebi uma alcunha, pois tinha feito uma promessa besta, uma coisa assim "se eu passar vou raspar a careca".Era só uma desculpa para raspar novamente a careca, já tinha raspado outras vezes.Então, quando subi a rampa da FFLCH, tinha um veterano recebendo os calouros, fazendo a lista, aí eu fui subindo e ouvi "Olha, temos a Pérola Negra do curso". Pronto, já recebi a alcunha de Pérola Negra. E tem seus prós e contras... Tem gente que me chama de Pérola Negra até hoje, daquele tempo. Ainda não consegui tirar...

Pensando os primeiros momentos da professora universitária dentro do território, vemos que, mesmo indiretamente, com suas leituras nos gramados aos finais de semana, ela ocupava uma rotina universitária, aquela vinculada ao estudo e ao aprendizado no campus. Estar presente, observando os diversos ritmos - a "vida" - de uma universidade como a USP, também lhe possibilitou criar em sua referência de futuro um importante desejo: o de formalizar sua presença como aluna do campus. Isso é muito importante, pois mostra o quão relevantes são os projetos de extensão (ROCHA, 2016) que envolvem fortemente a presença de jovens do ensino regular, levando-os a terem experiências dentro do território da USP.

O segundo momento revelado por Akilah é o dia da matrícula, que se torna a materialização de um sonho. Para um país onde o acesso a universidades públicas por parte de determinados grupos, como a população negra, é desigual, a matrícula ultrapassa o conceito de registro numérico e se torna um fator na luta frente à violência simbólica exercida contra esse segmento e que impede a sua mobilidade social (QUEIROZ, 2004). Porém, em um território predominantemente não negro, o reconhecimento dessa conquista pode ser seguido de um estranhamento em relação à presença de sujeitos não brancos nesse espaço.

Interpretamos que a alcunha "Pérola Negra" faz referência à cantora de samba Jovelina Farias Belfort, conhecida no mundo da música como Jovelina Pérola Negra. O vínculo estabelecido entre Jovelina e a recém-estudante da USP nada mais é do que uma face do racismo, que oferece apenas uma única visão (ADICHE, 2009) sobre o negro bemsucedido na sociedade brasileira: aquele que é jogador de futebol ou que está no mundo da música, criando situações em que, ao ver um negro em uma posição diferente daquela cristalizada pelo racismo, ocorre quase que imediatamente um estranhamento, como o que houve com Akilah.

O momento da matrícula também marcou a entrada no território da USP das estudantes Faizah e Baduc. No caso da estudante Baduc, além da matricula, sua primeira chegada no campus da USP foi ainda quando era estudante do ensino médio, como ela relata: 
Acho que a primeira vez foi em 2010 ou $2011 \ldots$ Era época do meu ensino médio. E aí eu vim pra cá, pro Instituto de Química, porque vim participar da segunda fase de uma Olimpíada de Química dos estudantes de ensino médio.

A oportunidade de estar dentro do campus é construída para os sujeitos por diversas situações. No caso da estudante acima, apesar de ela não explicitar se, nes se momento de sua vida, já tinha consciência sobre o que era a USP, é notório o valor de aproximação com a universidade ao participar das Olimpíadas de Química dentro do campus.

Também podemos ter outras situações para o que estamos chamando de "primeiro contato com o território". O professor Nassor, por exemplo, teve seu primeiro envolvimento na formatura do irmão:

Eu sou filho mais novo, então, tem meu irmão mais velho, cerca de 5 anos mais velho que eu, e tem minha irmã. Meu irmão tinha muito interesse por desenho, chegou a fazer um curso técnico de desenho e, na universidade, ele chegou fazer o curso de Química. Fez a graduação dele em Química e depois fez a pós-graduação dele, o mestrado dele em Química. Então a primeira vez que eu coloquei o pé aqui na universidade foi quando ele fez a defesa dele de mestrado aqui na USP. Isto por volta de 1999. Meu irmão foi a primeira pessoa da família a entrar em uma universidade, e a entrar em uma universidade pública também. A minha mãe era auxiliar de desenvolvimento infantil, a tia da creche. E meu pai era eletricista.

A trajetória relatada pelo professor é um caminho vivenciado por muitos negros que ingressam na vida acadêmica, carregando o sentimento de ser o único em um território onde não há majoritariamente referências dos seus pares. Os seus, na divisão social do trabalho, estão ocupando outros espaços que não o da academia e, por is so, ser o primeiro da família a entrar na universidade é sinônimo de realização não só para o quem ingressa nesse espaço, mas também para toda uma família que tem nessa conquista uma possibilidade de romper o abismo social que marca suas vidas(TEIXEIRA,2003).Para Nassor, essa representatividade do irmão pós-graduado tem um significado ainda mais gritante no que diz respeito às estatísticas sobre negros que chegam a essa esfera acadêmica, já que marca sua história como uma exceção à regra(SILVA, 2016).

Não à toa, lutar contra essa exceção tem sido uma das bandeiras de diversos cursinhos existentes dentro da universidade. Com o objetivo de permitir uma oportunidade de ingresso no vestibular, os cursinhos têm sido uma das formas de atrair de jovens de escolas públicas. 
Nesse sentido, encontrar um cursinho pré-vestibular foi o motivo que fez Yerodin entrar pela primeira vez na USP:

A primeira vez que eu pisei aqui foi em 2008, por volta de 2008. Estava à procura de um cursinho pré-vestibular para poder estudar, e eu sabia que existia alguma coisa aqui que eu poderia frequentar para ter as aulas e ficar mais inte irado no lance do vestibular. Foi juntamente com mais uns amigos, que também queriam estudar e tal.E aí foi um dia à noite. Foi à noite e estava deserto aqui. Você não encontrava ninguém, e aí a gente não conseguiu chegar onde queríamos. Acabamos voltando mais uma vez. Mas a primeira vez era de noite e eu fiquei achando estranho o lugar, porque estava vazio. Era tudo grande. Enfim. Mas eu não tinha conhecimento do lugar. Lugar bem novo.

Para estudantes negros egressos de escolas públicas de baixa qualidade, a chegada nas universidades envolve uma enorme desvantagem "ao competir com estudantes de outros segmentos raciais com uma história escolar bastante diferenciada"(QUEIROZ,2004,p.15).Para o estudante de Química Yerodin, a entrada na USP teve o objetivo de "driblar os obstáculos interpostos no seu trajeto escolar"(Ibid., p.16) a partir dos cursinhos que estão espalhados por vários pontos do território da universidade.

A combinação de uma significativa extensão territorial com a diversidade de pessoas -estudantes, servidores ou até mesmo moradores do entorno que transitam pelo campus - faz com que o USP Butantã se torne, além de uma geografia acadêmica, um espaço de socialização. Esse espaço de socialização entre os sujeitos que ali vivem também é característico, como é o caso dos estudantes de inúmeras regiões do Brasil e do mundo que vivem no Conjunto Residencial da Universidade de São Paulo (CRUSP).

O caso da servidora Nyota se confunde com esse fato de a universidade também se revelar como um espaço de socialização. Suas primeiras visitas à USP foram realizadas para encontrar amigos africanos que moravam no CRUSP:

\footnotetext{
Ah, na verdade eu vim na USP, eu acho antes de me tornar servidora, pois eu conhecia alguns africanos. O movimento negro tinha muito contato, acho que tinha uma relação muito mais próxima nos anos $80 \mathrm{com}$ a comunidade africana do que tem hoje.Então eu vim, tinha um amigo - que se tornou reitor lá em Moçambique -, o Mazula. Quando ele era aluno aqui, eu o conheci a partir de outra amiga e tal, e a gente veio, numa visita aqui, num almoço, e depois o convidei para ir na minha casa. Nos tornamos grandes amigos e depois ele voltou para Moçambique. Foi um dos caras que trabalhou no processo de paz. Então,já é dentro da militância negra, como ativista política, com a África da diáspora, que eu tinha essa relação com a universidade.
} 
Assim, é no encontro com a comunidade africana que também está presente via intercâmbios e parcerias entre universidades brasileiras e africanas que a servidora tem seu primeiro contato com a universidade. É curioso pensar es sa internacionalização das relações como uma possibilidade de um intercâmbio cultural e político dentro do campus da universidade que, para a servidora, ecoou não só no fortalecimento de uma amizade, mas também no seu vínculo com a militância negra.

\subsubsection{Tornando-se parte da USP como estudante}

O primeiro encontro com a universidade, revelado por cada uma dessas histórias, atingiu, apesar da singularidade de cada uma delas, os sujeitos de forma semelhante no que diz respeito à constituição de um vínculo-chave para a possibilidade de um futuro para esses sujeitos na comunidade negra da USP. Desse modo, conhecer a universidade significou uma importante ponte para aproximar suas vidas e esse espaço universitário. Porém, a individualidade, que se caracteriza como uma marca da trajetória de cada sujeito, faz com que cada um deles tenha narrativas diferentes quanto às razões e situações que fizeram cada um deles escolher a Universidade de São Paulo como espaço de estudo e/ou trabalho de suas vidas. O processo de desejar estar na USP, seja como estudante, seja como servidor, conversa com as condições sócio-raciais da população negra de São Paulo. Tornar-se parte do território da universidade é, então, uma estratégia de fuga das circunstâncias negativas atreladas ao seu corpo negro, corpo que é marcado por:

Processos inscritos em injustiças, em etnocentrismos, hierarquias e clivagens socioeconômicas implicados em sistemas simbólicos demarcados por uma cultura eurocêntrica branca, machista nos quais os pobres e os negros, ou, de outra forma, os negros pobres foram desde os tempos remotos alijados do conhecimento e das instituições acadêmico-cientificas. (PRAXEDES, 2009, p. 17)

Um dos aspectos que se destaca entre os motivos que os fizeram entrar no território de forma oficial é o método de transparecer suas trajetórias diferenciais como negros que, como pontua Vanda Lúcia Praxedes (2009), são "processos inscritos em injustiças”.

No caso dos(as) estudantes negros(as) entrevistados(as), suas narrativas mostram os diversos obstáculos travados para a conquista do número de matrícula na USP, que, como já vimos, ultrapassa o caráter numérico ao ter também um traço simbólico. É o que Teixeira(2003) pontua como "trajetórias ascendentes", ou seja, aquelas que vinculam o 
discurso a um processo de ascensão social que é iniciado por eles(as) mesmos(as) a partir de sua geração.

Para o estudante de Química Yerodin, essa trajetória se inicia no ensino fundamental:

Foi assim:uma trajetória que começou no ensino fundamental...[...]Parece que foi meio acaso quando eu falo assim. Foi na casa de um amigo, que tinha uns livros de Matemática, e eu comecei a folhear os livros.Eu fiquei curioso e queria saber mais sobre aquilo. Eu tinha muito tempo ocioso, ficava tocando instrumento. Boa parte do meu dia jogava bola. Estava no ensino fundamental ainda, meus pais ainda não me cobravam o lance de trampar e ajudar em casa. E aí eu fui levando isso na oitava série. Na oitava série fiquei no primeiro ano estudando, os professores estimulavam. Depois fiquei mudando de escola, fui conhecendo pessoas novas que também queriam estudar. A gente resolveu escolher uma universidade pública. A gente sabia que não tinha condição de pagar tipo 800 conto em uma mensalidade nos cursos que a gente queria. Aí mano, o que restava pra gente era a universidade pública. Alguma coisa incentiva a gente a ir pra universidade pública. [...] A gente tinha uma coisa bem compromissada mesmo, era um lance de "Ah... A gente vai estudar o que hoje?"; "A gente precisa estudar matemática, mas se você tem dificuldade pra Matemática, quem sabe um pouquinho mais vai escolhendo os exercícios, vai mostrando como fez para os outros também fazerem". Isso aí foi no ano de 2008, inclusive foi $\mathrm{o}$ ano em que eu vim aqui na USP. Depois a gente foi prestando o vestibular. A gente viu que era difícil, a gente não conseguiu atingir a pontuação. A gente conseguiu estudar só por um ano porque eles, os outros, precisavam trabalhar também. Eu também já estava trabalhando e tinha ficado um ano sem estudar. Saí da escola e teve um ano que estudei e trabalhei ano inteiro! Então deu pra dar uma animada no ano seguinte. Em 2009 tive que arranjar um outro trampo, porque não passei na faculdade, e ainda veio uma cobrança em casa; tinha que trampar. Ficava trampando e aí, quando chegava em casa, dava uma lida em um livro de Biologia e de Português. Isso fui trampando e estudando até 2012, que foi o ano que entrei aqui.

Conciliar trabalho e estudo se torna, nesse percurso de Yerodin, um dos obstáculos enfrentados para conseguir alimentar o sonho de estar em uma universidade pública. Trabalhar é algo constantemente cobrado de um jovem da periferia de São Paulo não somente para sanar vontades individuais, mas também para complementar a renda da família. Em sua fala, que é uma mistura de diferentes tempos até o ingresso na USP em 2012, podemos perceber que o jovem da zona norte da cidade São Paulo tinha a consciência de que, mesmo sendo árduo, entrar na USP seria a única forma de poder cursar uma universidade, já que em uma universidade particular teria que trabalhar para pagar a mensalidade. O estudante também pontua que existe "algo incentivando" nessa trajetória narrada, em que a organização construída entre o grupo de amigos para estudarem juntos - que nada mais é do que um espaço de solidariedade - e a própria condição social vivida por eles podem ter sido os 
principais fatores de motivação para um estudante advindo das camadas mais baixas da população encontrar forças para persistir e conseguir a matrícula como aluno da USP, mesmo com as dificuldades.

Outro caso em que o trabalho surge no percurso de entrada para a universidade é o da estudante Baduc. De forma semelhante, a estudante também acaba sendo cobrada pela família por não estar trabalhando, como ela revela:

Terminei o ensino médio em 2011 e pensei que eu queria entrar na Universidade de São Paulo. Nessa época eu queria fazer Geologia. Eu amava Geografia... Amava Geografia Física, tipo os mapas e tal. Falei "mano, quero muito fazer isso...". Eu tinha um sonho de tipo fazer, trabalhar na Petrobrás.Prestei vestibular naque le ano, foi assim muito desmotivada, não fui muito bem.Não alcancei a nota de corte e aí decidi que eu faria cursinho no ano seguinte.Eu fiz um cursinho popular que é da prefeitura lá de Barueri e os professores eram todos estudantes aqui da USP, então isso também me deu muito gás, e eu insisti no negócio da Geologia. E aí fiz cursinho no ano de 2012, prestei vestibular e não consegui passar pra segunda fase... A nota de corte tava alta... E aí falei: "não, vou fazer um segundo ano de cursinho". E aí foi um rolê porque minha mãe falou: "Olha né, 19 anos e tal... Não vai trabalhar?".E aí eu tive que arrumar um emprego no telemarketing lá em Alphaville, que é uma região que fica dentro da cidade de Barueri que é riquíssima... É bizarro.E aí fui trabalhar lá.Era péssimo. Odiava aquele emprego. Pior dos empregos do mundo que se pode ter é telemarketing... E aí fiquei um tempo lá, uns meses. Fiz no ano de 2013 cursinho novamente e eu comecei a mudar. Tinha professores, assim muito bons, que eu sempre gostei.Eu sempre gostei das áreas de humanidades,de Geografia principalmente, e também História, Sociologia, Letras e tal... E aí comecei a pensar: "Putz, e agora? Acho que não quero mais fazer Geologia... Acho que se pá eu deveria ir para a Geografia".Só que eu não sei, eu não lembro direito... Tipo eu acho que eu me encantei mais pela História naquele momento e aí, ao invés de ir para a Geografia, que parecia o caminho mais óbvio, eu decidi ir pra História, que acho que até tinha uma nota de corte maior, mas enfim... E aí passei, né? Estou aqui.

Diferentemente de outro caso, Baduc revela que teve a oportunidade de estar em um cursinho popular onde havia professores formados na USP e que deram um "gás" nos seus estudos. As referências que esses educadores deram para a estudante lhe permitiram visualizar a possibilidade de entrada em uma das maiores universidade do país. Ela se interessou em um primeiro momento pelo curso de Geologia, mas, a partir da sua relação com as aulas, aproximou-se da área de humanidades, encantando-se com o curso de História. Esse maior envolvimento também pode ter conseqüentemente oferecido respostas para as cond ições sociais e raciais vividas por ela, em que determinados temas podem ressoar não só na sala de aula, mas também na vida da estudante negra. 
Não muito diferente foi a história revelada por outra estudante negra entrevistada, a Faizah, como ela revela abaixo:

Até meus 18 anos eu tinha uma outra mentalidade sobre o curso, sobre a vida. Estava passado por uma crise pessoal e de frustração também em relação às minhas possibilidades na vida, etc. Estava trabalhado e pensando em viajar, só que até então eu não tinha condição de viajar, e aí decidi conhecer minha própria cidade - foi o momento "eureca" na minha vida, sabe? Conhecer minha própria cidade, conhecer a especificidade dela, a história. E aí felizmente eu me encontrei dentro da Arquitetura, a parte desse meu desejo pessoal de conhecer minha própria cidade. E assim que decidi fazer Arquitetura. Eu já estava no meio do ano, eu já tinha feito ENEM no ano anterior. Eu morava em Belo Horizonte e a UFMG já tinha fechado as inscrições $\operatorname{logo}$ no início do ano tanto pro primeiro quanto pro segundo semestre. E aí o que eu podia fazer para estudar naquele primeiro período era entrar pelo PROUNI ${ }^{41}$. E aí foi que decidi fazer mesmo. Estava trabalhando na época, era um trabalho muito maçante. Estava afim de sair dali e voltar para sala de aula. Aí consegui entrar pelo PROUNI na PUCMinas. Fiquei um semestre, eu gostei muito, muito, muito mesmo, só que sabia que não queria ficar em uma faculdade particular, que iria para uma universidade pública, porque no ensino médio eu fiz o $\operatorname{COLTEC}^{42}$, que é o colégio técnico da UFMG, um colégio que fica no próprio campus da universidade, então eu já tinha dimensão do que uma universidade pública poderia me oferecer e das possibilidades que poderia ter, principalmente se tratando das ações afirmativas de permanência. Estava em uma faculdade particular e, mesmo com bolsa, não estava muito favorável para mim. Então no mesmo ano que estava na PUC - Minas, eu fiz inscrição pro Enem de novo e tive uma nota boa e tal. Me inscrevi na UFMG e, por coincidência, procurando a lista do SISU, eu vi a USP. Eu nem sabia que a USP tinha entrado, aberto vaga pelo SISU. Fui pesquisar, saber, para ver se era verdade essa história toda e vi que tinha havido greve na FAU, e uma das pautas da greve desse ano de 2016, se não me engano, foi a questão da exclusão da prova de habilidade específica e a abertura de vagas pelo SISU. Então, eu achei um momento muito oportuno. Me escrevi imediatamente e consegui aprovação. Foi um encadeamento de coisas, que deram certo, felizmente.

Foi um "encadeamento de coisas" que ocorreu na vida dessa mineira que decidiu não só mudar de universidade, mas também de cidade. Ter estudado em um colégio de aplicação dentro da UFMG trouxe para a estudante de Arquitetura uma perceptiva a respeito da importância de ocupar uma universidade pública. Sua vivência no COLTEC revelou o quanto uma instituição pública é capaz de agregar e, por isso, mesmo estando em uma universidade particular de qualidade, optou por estudar na USP quando essa oportunidade foi conquistada.

\footnotetext{
${ }^{41}$ O Programa Universidade para Todos (PROUNI) foi criado em 2004 e tem como objetivo principal conceder bolsas de estudo integrais ou parciais em cursos de graduação e sequenciais específicas de formação em universidades privadas de todo o Brasil.

${ }^{42}$ COLTEC é o Colégio Técnico da UFMG, u ma escola técnica federal que, desde 1969, atende alunos do ensino méd io em Minas Gerais
} 
Ao analisar os três casos dos estudantes entrevistados vimos que, apesar de terem diferentes histórias e geografias ${ }^{43}$, seus percursos se assemelham no que diz respeito ao trabalho, já que em algum momento de suas vidas eles tiveram que procurar emprego para manter o sonho de ingressar em uma universidade pública. No caso da estudante de Arquitetura Faizah, houve um diferencial quanto à escola cursada no ensino regular, sendo a única que, em sua formação, teve o curso técnico-federal, inclusive já dentro de uma universidade pública.

\subsubsection{Tornando-se parte da USP como servidor(a)}

Quando nos voltamos para os(as) servidores(as) negros(as) da USP, vemos que os caminhos para pertencerem ao corpo de trabalho da universidade se tornam diferentes. A característica que se destacou na entrevista com esses trabalhadores(as) foi a rede de solidariedade criada a partir das indicações de vagas por parte de familiares e conhecidos que poderiam ajudar na execução de um projeto de mudança social (TEIXEIRA, 2003).

Assim, quando Nyota foi questionada a respeito de sua trajetória para se tornar servidora, ela traz a questão da indicação do serviço por algum conhecido, como também aparece no relato dos demais:

Foi uma amiga.Na época ela era estudante de Biologia, não aqui na USP.Eu trabalhava no laboratório de análise no Servidor Público Estadual, na Patologia, e na emergência da Santa Casa. Fazia faculdade à noite, e aí essa amiga minha, muito próxima de mim, me falou de uma vaga para nível médico aqui.Fiz uma entrevista, apresentei currículo, concorri pra vaga, ganhei fui aceita.

Outro caso semelhante de indicação é o da servidora Karassi:

Então, entrar na universidade para mim, ainda que como funcionária e não como aluna, foi bastante gratificante, porque era um sonho meu trabalhar com criança, porque antes da USP eu trabalhava com adultos, fazia coordenação de adultos. Eu coordenava adultos para que eles pudessem trabalhar com criança, trazer biografia com as meninas e tal, para eles terem alguma referência. Mas como meu sonho era trabalhar com criança quando vim pra cá fiquei muito feliz. Fui com um convite de uma amiga.Eu fiz magistério depois e com um tempo fiz pedagogia. Essa amiga já conhecia um pouco da minha história e disse: "Estão chamando, vão pegar pessoas lána USP, vai lá fazer inscrição". Eu passei em quarto lugar. Foi uma honra muito grande pra mim.

\footnotetext{
${ }^{43}$ Os dois primeiros casos sendo em diferentes regiões de São Paulo e o terceiro caso tendo origem em Minas Gerais.
} 
Tanto o caso da Karassi como o da Nyota foram casos em que as indicações de vagas vieram de uma "amiga próxima". Outro fato muito interessante é que as servidoras já trabalhavam antes mesmo de entrarem na universidade: no caso da Karassi, ela desenvolvia serviços relacionados à educação, trabalhando com adultos, enquanto Nyotajá estava realizando trabalhos em laboratórios.

O que lhes fez escolher trabalhar na Universidade de São Paulo?A trajetória do servidor Lutalo pode responder essa pergunta levantada:

É então por meio desse meu tio, que eu falei que trabalha aqui. Ele, meu pai, já haviam tentado inúmeras vezes prestar concurso público aqui. E uma das coisas, sei lá, que hoje parece ser em vão, que não tem muito sentido, é a questão de você entrar aqui e ser um lugar seguro para trabalhar. Aqui não é como uma empresa privada que manda embora quando satura, ou algo do tipo.Então, era uma coisa que desde moleque via meu pai passando, essa questão de entrar dentro da universidade como trabalhador,prestando concurso, processo seletivo...Então depois que me tornei maior, independente, comecei a prestar também. Depois de vários concursos, consegui entrar como servidor!

Lutalo traz algo novo. Como as servidoras anteriores, ele também teve uma indicação de um conhecido, no caso o tio, que já trabalhava na USP e se tornou uma referência para conseguir o emprego na universidade. Porém, é importante destacar um aspecto da sua fala e que pode responder à pergunta anterior: estar trabalhando na universidade pública é uma garantia de segurança social e financeira para o trabalhador negro, que não precisaria se preocupar em ser "mandado embora", como é a realidade instável de uma empresa privada. Dessa forma, Lutalo cresceu com essa estratégia, que visualiza no caráter democrático do concurso público (YONE, 2009) a possibilidade de participação em um trabalho possível e seguro. Por isso, conseguir o vínculo como servidor é como se desmoronar uma muralha que impedia sua entrada.

\subsubsection{Tornando-se parte da USP como professor(a)}

Entrar como professor(a) negro(a) na Universidade de São Paulo representa também um enfrentamento de muralhas simbólicas no espaço do ensino superior público, pois são narrativas que envolvem dimensões cruciais aos sujeitos negros (GUSMÃO, 2009) na universidade. Suas trajetórias são "pontos fora da curva", já que representam funções em que não são usualmente encontrados (SILVA, PÁDUA, SOUZA, 2009). Na presente pesquisa, 
isso permite não só uma pluralidade no que diz respeito aos sujeitos, mas também às relações raciais que se desenvolvem dentro do campus Butantã. Nassor e Akilah, apesar de serem parte de categorias diferentes nos ramos da educação, tiveram que passar pe lo processo de concurso público para ingressarem como professores dentro do território da USP. Porém, o processo de prestar o concurso, para a professora Akilah, não significou ter a confiança de enxergar-se dentro do campus, como ela revela:

Olha, isso também foi um susto, porque em nenhum momento eu havia imaginado que um dia eu iria me tornar professora da USP. Não tinha esse intuito. Fui fazendo as coisas, fiz a graduação, depois eu vou fazer o quê? Já estava dando aula no ensino fundamental, mas eu queria dar aula para faculdade também, mas não era na USP; não estava nos planos. Aí eu entrei no mestrado. Estava no mestrado, um colega me convidou para dar aula numa faculdade privada, perguntou se eu queria dar umas aulas lá para ele, que ele estava deixando, e eu disse "eu vou". Era uma vez por semana... Tinha curso de formação de professores de História e Geografia primeiro e segundo ano comum, terceiro e quarto ano para alunos de ano superior em História e Geografia. Foi uma turma legal. Eu fiquei 15 anos por lá. E fui estudando... Senti necessidade de continuar estudando. Concluí o mestrado,continuei estudando e aí entrei no doutorado, mas ainda continuava na inic iativa privada.

Eu não tinha essa intenção de entrar na USP realmente. Prestei o concurso mais para saber como era prestar o concurso na USP. Muita gente falava "presta o concurso, já tá lá, presta, tenta, o concurso". Nós éramos 9 candidatos, só 7 apareceram para fazer a prova. Eu prestei o concurso sem a menor intenção de entrar, embora durante o processo, de 3 a 4 dias de provas, eu cheguei aqui dizendo pro meu irmão: "eu fui muito bem nas provas". Era um tema que eu dominava bem, eu estudei bastante no concurso, a aula didática, acho que foi a melhor aula que dei na minha vida! Tudo no devido lugar. Deu certo, e no sábado de manhã eles iriam anunciar quem tinha passado no concurso. Eu estava na feira, comendo pastel, tomando caldo de cana com uma turma de amigos. Eu comentei sobre o concurso era umas $11 \mathrm{~h}$ da manhã, e aí eles disseram: "Mas você não vai lá para saber o resultado?". Eu respondi: "Eu não, eu não passei, eles vão anunciar meio dia, eu não vou, não". Eles disseram "Você vai lá sim, vamos te levar até a porta para você ver se você passou ou não". Eu estava com uma roupa de verão, toda à vontade, não estava com uma roupa de professora. Me enfiaram no carro, me deixaram na porta da faculdade.Quando anunciaram, eu tive um piripaque.Eu não acreditei, eu não acreditei. Fiquei sem acreditar uns 10 dias. Tiveram que me ligar e disseram: "Ô professora, você precisa tomar as providências". Eu disse: "É de verdade?!". Eles me confirmaram: "É de verdade". Foi um susto. Foi um susto grande. Não esperava. Quando cheguei em casa chorando, meu irmão perguntou "Porque você tá chorando? O que fizeram com você? O que eles falaram com você lá!? Eu respondi "Eu passei!"[risadas]."Como você passou?"; "Eu passei!!!”. Foi um susto coletivo [risadas]. Eu fiquei uns 10 dias para tirar o que estava acontecendo comigo da minha cabeça. Então foi um susto, não foi um projeto de vida. Aconteceu. 
"Foi um susto", como a professora pontua inúmeras vezes. Sua repetição faz até confundir a sua conquista com um acidente. Não acreditar no que aconteceu ao saber que havia passado - a ponto de ficar inerte por dez dias quanto ao seu ingresso - e a forma como o irmão recebeu a notícia ao vê-la chorando, imaginando que algo ruim havia ocorrido, foram momentos de grande impacto. Foi um choque silenciosamente organizado, já que a maneira como foi amadurecendo sua vida acadêmica indiretamente permitiu a abertura de um possível caminho para se tornar professora de uma grande instituição. Porém, tornar-se e reconhecerse professora da USP são processos diferentes na narrativa de Akilah, que anula, mesmo tendo prestado o concurso, a possibilidade de conferir seu nome na lista de aprovados. Foi preciso a insistência de amigos para Akilah ir verificar o resultado, pois internamente o auto boicote moderava suas ações. Esse autoboicote está diretamente relacionado à autoestima da população ne gra, parte operante para compreender as relações raciais entre os sujeitos negros na sociedade.

A fala da professora Akilah direciona o olhar deste estudo: aquele que valida a importância de analisar o que é ser negro dentro da USP como forma de aproximação da discussão que envolve as relações raciais não apenas dentro, mas também fora do campus e, assim, compreender como se dá essa ascensão social.

“Torna-se negro" é um processo, como já explicado por Neuza Santos Souza (1983), pois a identidade do negro brasileiro é fruto de uma dolorida batalha psicológica marcada pelo racismo, que cria barreiras que dificultam o reconhecimento da corporalidade negra e de sua individualidade. No caso da população negra, que ocupa múltiplos espaços da universidade, seja como estudante, seja como servidor(a), a história de violência sobre sua corporalidade é marcada por inúmeras situações que os farão perceber o que é ser negro dentro da USP. 


\subsection{Ser negro(a) dentro da USP}

É você olhar pra mil pessoas e não ver ninguém parecido com você. É isso.

- Faizah

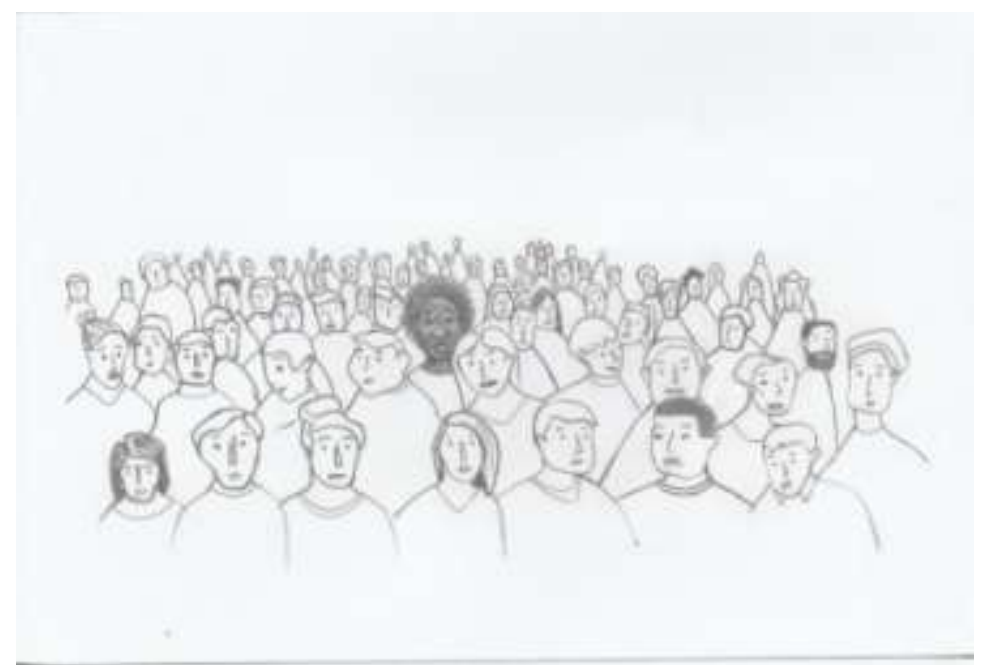

Figura 7 - A Solidão Negra.

Créditos: Isadora Almeida Simões (2019) ${ }^{44}$

Nesta parte do trabalho organizamos nossa escuta para experiências particulares sobre o reconhecimento dos sujeitos quanto aos seus corpos negros no território da USP. São histórias que revelam a consciências que os(as) entrevistados(as) possuem sobre a presença da sua corporalidade negra dentro do campus Butantã da Universidade de São Paulo. Apesar de apresentarem falas com diferentes perspectivas sobre aspectos que relacionam suas identidades com o território, suas vivências como pessoas negras formam uma narrativa comum, que remete ao debate sobre a democracia racial brasileira, uma democracia mitológica, que influencia diretamente as diversas relações que envolvem a população negra e que marca o reconhecimento desses sujeitos no que diz respeito à sua identidade negra dentro da USP.

A breve, mas significativa resposta de uma das nossas entrevistadas, a Faizah, utilizada como epígrafe deste subcapítulo, descreve, na ótica de uma estudante negra que ocupa o território da universidade, a ausência de uma representatividade negra, anunciada em valores numéricos no primeiro capítulo deste trabalho, que trouxe uma reflexão sobre a problemática quantitativa de estudantes negros que estão matriculados nos cursos da universidade. Todavia, para a estudante de Arquitetura, ser negra não é apenas um fator quantitativo que faz alusão à sua presença, ou seja, seu corpo, mas também uma lente de

\footnotetext{
${ }^{44}$ Todos os desenhos aqui apresentados foram feitos a meu pedido pela colega Isadora Almeida Simões como forma de ilustrar as questões tratadas neste capítulo e suscitadas pelas entrevistas.
} 
identificação com seus pares. Não reconhecer "ninguém" na mesma condição e posição que a sua cria uma sensação de esvaziamento ou mesmo de solidão.

Ao conversarmos com Baduc, as primeiras palavras ecoadas também tiveram vínculo com a ideia de solidão:

É... Ser mulher negra na USP é um sentimento de muita solidão. É muita solidão. Solidão. Eu vou te dar alguns exemplos, tá? Tem a solidão primeira, que é esta que falei do episódio da época da Ocupação Preta ${ }^{45}$.O professor cancelou a aula e, na semana seguinte eu, como aluna dele, sozinha, me levantei, fiquei em pé e disse: "Professor, porque o senhor cancelou a aula?" E eu perguntei para a sala "Pessoal, porque vocês não falaram nada? Porque o professor cancelou a aula? Tem um pessoal que vem de Campinas, e o professor cancelou aula?".E ele falou assim: "Posso responder? Eu acho que posso responder. Eu acho que primeiro, se seus colegas não falaram nada é porque todo mundo entendeu e ninguém se importa. Segundo,eu cancelei minha aula porque eu não entendi muito bem o que é esse movimento, sabe?Eu achei muito obscuro, muito radical e percebi que esse grupo não estava ligado ao MNU [Movimento Negro Unificado], então eu decidi cancelar e depois eu conversei com alguns parentes meus que são juristas, que são advogados, e eles me falaram que foi a melhor decisão a ser tomada". Ele deu essa carteirada básica. Exigiu nossa carteirinha do Movimento Negro Unificado e ninguém falou nada! Teve uma menina que disse "Não, professor, não é assim. Eu quero saber porque você cancelou a aula".Ele cortou ela e disse: "Não, querida"[risadas]. Foi machista e cancelou a aula. Esta foi a minha experiência de solidão mais assim em sala de aula. Porque não é como se as pessoas não soubessem, porque existiam amigos meus que estavam nessa sala, amigos brancos. Existiu um cara negro, que não era meu amigo, um cara negro militante, que depois que saiu da aula fez um post dizendo "Ai, uma colega negra falou, e eu fiquei tão triste em ver o professor dar carteirada". E ele não fez nada! Então, essa experiência de solidão é muito profunda. [...]

O primeiro relato oferecido pela estudante é de uma situação vivenciada em sala de aula que marcou não somente o seu isolamento quanto ao reconhecimento da importância do debate racial em sala de aula como também delimitou o posicionamento do professor sobre a relevância da organização negra estudantil. Ele hierarquizou o movimento negro ao dar um respaldo maior para uma organização tradicional e subestimar as estratégias contemporâneas propostas por novos grupos, que têm reivindicado ações diretas no combate ao racismo estrutural. O sileciamento é, nesse sentido, característica da violência simbólica sofrida pelo corpo negro que, em diferentes situações, é colocado em xeque.

No caso ocorrido, a estudante de História ainda é alvo da violência pelo seu corpo feminino, já que, no Brasil,por causa dos estereótipos gerados pelo machismo e o racismo,ser

\footnotetext{
${ }^{45}$ Coletivo de estudantes negros(as) da Universidade de São Paulo.
} 
uma mulher negra é estar nos mais baixos níveis de opressão(GONZALES,1982).Essa opressão é materializada pela forma como o professor se coloca em sala de aula, até mesmo no tom possivelmente ameaçador - ao declarar que tem parentes advogados -, que nada mais é do que seu deslocamento como homem frente a uma aluna mulher. Ainda sobre o evidente sileciamento na sala de aula, o fato de o seu colega negro e militante não ter se colocado chama atenção na fala da Baduc. Contudo, é importante salientar que existem relatos que relacionam esse tipo de bloqueio a casos semelhantes ao do aluno, seja pelo imaturo envolvimento com o debate racial, seja por um trauma vinculado a repetidas situações de violência contra o seu corpo.

Baduc, além disso, não restringe o seu sentimento como mulher negra apenas ao que aconteceu na sala de aula, trazendo para nós mais um relato, dessa vez envolvendo outro professor:

Teve um dia que estávamos discutindo o material didático, e eu fiz um questionamento sobre o capítulo que a gente não revisou no nosso grupo, que fala da Revolta da Vacina. Eu achei bem ruim, porque não tinha quase nada falando da questão negra [...]. E aí a discussão continuou. Um dos colegas disse "Ah, no nosso livro não falava muito da questão, eu não dei muita importância, porque o livro é de 2002, e a lei 10.639 é de 2003 , não tinha obrigação ainda, tudo bem não ter"[...]. E aí eu mandei um e-mail falando sobre isso "Olha, professor, não é possível, a gente vai falar sobre Revolta da Vacina, e a gente não fala da questão negra?" [...] E eu disse: "Professor, você sabe quanto racismo a gente enfrenta dentro da escola, dos colegas, dos professores, da diretoria, e agente não está falando sobre isso nem na sala da escola. A gente não está pensando nesse tipo de coisa, professor. Eu tô fazendo o teu estágio em uma disciplina em uma escola lá do Capão, e o único menino negro que faz parte do projeto super legal da escola, que agente conseguiu entrevistar,a gente descobriu depois que ele se chamava de escravo. Ele se chamava de escravo na zoeira com os colegas. Os colegas brancos me falaram isso"[...].Aí, enfim, ele disse: "Baduc, eu entendo tudo isso...Essa cultura do racismo, machismo.Você tem toda razão.Vamos conversar no final do curso". Procurei ele no final do curso, fui na sala dele, falei tudo isso que eu estou falando agora.Ele disse que entendia. Eu falei: "Se o racismo é estrutural e se você entende que o racismo é estrutural na cultura brasile ira, porque a gente não pode pensar em um curso que se estruture a partir da discussão da questão negra? Porque a escola não pode ter esse papel?" Aí ele disse que nunca tinha pensado nisso, mas que ele era preocupado com a questão negra, tão preocupado com a questão negra que ele tinha como provar. Aí ele me falou assim: "Olha, eu escrevi um livro sobre o negro no Brasil, na educação". Ele no final foi me falando: "Baduc, você tem razão, de repente montar um curso que se estruture a partir disso seria bom. Muito legal que você me procurou. Bacana. Fiquei feliz". E ele terminou falando assim: "Olha, só tenho uma última coisa pra te dizer[suspiros]. Eu sinto que você oscila em momentos de diálogo. Quando você me mandou esse e-mail e agora, é o momento que você não tá afim do diálogo, e aí eu percebo que você é muito expressiva na sala de aula. Você faz muitas caras e bocas para os seus colegas, e eu acho 
que isso pode afastar as pessoas porque você não está criando diálogo, porque você poderia ser menos agressiva na sua abordagem" [...] Esses casos dão bem um panorama do que é ser uma mulher negra na USP.É tipo isso, ser desvalorizada, pedirem o teu crachá do MNU, é ser preterida até mesmo por aqueles que eu acho que estão do meu lado e que acreditam que estão do meu lado, é ser chamada de agressiva.

A denúncia realizada pelo olhar técnico de uma estudante que percebeu as fragilidades conceituais do livro didático no que diz respeito a uma historiografia negra carioca é ofuscada pelo desconhecimento do assunto por parte dos colegas. Mesmo sendo confrontados com os argumentos da estudante, eles insistiam em afirmar a naturalidade do problema da inviziblização do corpo negro carioca no episódio da Revolta da Vacina. Baduc acaba sendo, nesse estado de isolamento conceitual, uma problematizadora, posição que, em um primeiro olhar, não é necessariamente ruim, mas o fato é que, nesse estado de isolamento, a problematização das questões que envolvem o negro brasileiro levam à lógica estereotipada do negro complexado e agressivo. No caso da leitura realizada pelo professor sobre a argumentação da aluna, há um olhar estereotipado a respeito da "fala emocional" (GONZALES, 1979, p.15) presente no discurso das mulheres negras. Sobre essa fala emotiva, Lélia Gonzáles explica que:

No momento em que denunciamos múltiplas formas de exploração do povo negro, em geral e da mulher negra em particular, a emoção, por razões óbvias, está muito mais em quem nos ouve.Na medida que o racismo, enquanto discurso, situa-se entre os discursos de exclusão, o grupo por ele excluído é tratado como objeto e não como sujeito. Conseqüentemente, é infantilizado, não tem direito à voz própria, é falado por ele. E ele diz o que caracteriza o excluído de acordo com seus interesses e seus valores.No momento em que o excluído assume a própria fala e se põe como sujeito, a relação de quem ouve só pode se dar nos níveis acima caracterizados. $\mathrm{O}$ modo mais sutilmente paternalista é exatamente aquele que atribui o caráter de 'discurso emocional' à verdade contundente da denúncia presente na fala do excluído [...]. (Ibid., p. 15)

A conduta que a corporalidade da estudante negra assume em sala é uma consequênciado silenciamento de sua voz. Esta, quando manifestada, é vista com estranhamento por parte dos ouvintes que, não acostumados com o posicionamento ativo dos sujeitos marginalizados, enxergam essa reação como "agressiva", "expressiva" ou com "caras e bocas". Essa postura é fruto de uma ruptura de paradigmas que incomoda ao ser realizada. O excluído, ao assumir a voz, fala por si. Quase que simultaneamente, como uma forma de defesa que marca a normativa que rege a democracia racial brasileira, o professor assume a posição de ouvinte.Entretanto, essa posição é temporária, pois logo infantiliza toda 
argumentação da Baduc com um panorama em que a coloca novamente na posição de complexada.

À luz dessas reações, Lélia Gonzalez explica que a emoção é para nós outra razão:

Para nós, é importante ressaltar que emoção, subjetividade e outras atribuições dadas ao nosso discurso não implicam numa renúncia à razão, mas, ao contrário, num modo de torná-la mais concreta, mais humana e menos abstrata e/ou metafísica. Trata-se, no nosso caso, de uma outra razão.(Ibid.,p.16)

Esta "emoção,subjetividade e outras atribuições"calibram o pertencimento dos corpos dos entrevistados a partir do que é vivido dentro e fora do território da USP e fazem com que, em suas narrativas, construam análises comparativas para entenderem sua pertença e tirarem conclusões, como foi o caso do servidor Lutalo, que concluiu que não há diferença entre ser negro na USP e fora da USP:

Acho que ser negro na USP não é diferente [de ser negro]no resto da sociedade, sabe? O cara que é racista aqui dentro é o mesmo cara que é racista lá fora. Não há diferença.

Para Lutalo, ser ou não ser negro é mediado por um sujeito:o racista.Este, que é a personificação da ideologia racial, põe em práticas as asperezas montadas pela falsa democracia racial, sentida diretamente pelo negro em suas relações diárias. Essa fala do servidor também nos faz refletir sobre estar dentro do território da USP, onde possuir certa autonomia como instituição perante as leis externas não significa em nenhum momento a inexistência de pessoas racistas nesse espaço, pois "o cara é racista aqui dentro elá fora". Vem ao chão, assim, qualquer esperança de acreditar em uma postura diferenciada por estar em um espaço acadêmico, uma vez que situações ocorridas lá fora, vinculadas ao seu corpo negro, poderão, sim, ocorrer também na USP.

A conversa que tivemos com Fela também revelou aspectos parecidos com aquele apresentado por Lutalo:

Eu acho que ser negro dentro da USP é ser negro no Brasil, com tudo que tá implicado aí. Entendeu? Eu lembro que sempre fui servidor. Quando fui ser aluno, por exemplo, eu tinha comigo que a hora que eu ia fazer universidade, a hora que eu queria entrar aqui eu entraria. Eu senti que tinha um estranhamento quando alguns professores me viam em sala de aula, porque eles me conheciam há muito tempo como o cara pretinho da biblioteca. Não sei, os caras ficam imaginando "Ah! Ele está fazendo uma 
disciplina...". Porque eu lembro que eu evitei de ver uma aula, eu ficava com uma sensação que os caras ficavam estranhando até que meu nome aparecesse lá na lista mesmo. Aí pensavam: "Acho que o cara fez FUVEST, entrou aqui mesmo". Pode ser uma piração minha, mas não sei se é uma piração, não. Tem isso, né? Cara, o negro é sempre um negro. Uma coisa que me chamava atenção, uma sensação que era interessante: por exemplo, um negro cruzando com outro na rampa, numa situação não como servidor, é meio um susto, é como se olhasse pro espelho e tomasse um susto, pois todos os outros, você pega os orientais, por exemplo, eles se juntam, mas o negro não se permite se juntar, se aglomerar.O negro na universidade é o negro em qualquer lugar porque a aglomeração do negro suscita meio que uma sensação de pânico, meio que de inquietação e incômodo nas pessoas. Parece um bagulho tão louco que, quando cheguei a comentar com alguns colegas, que nos automonitoramos para não nos permitirmos estar aglutinados, pois isso pode gerar um olhar tipo "os caras estão conspirando". Tem esse negócio, que é muito louco. Você pode reparar que nos restaurantes coisa e tal era raro ver uma mesa só de preto porque o negro nem sempre se aglomera para não gerar um incômodo, uma inquietação de quem pode pensar "olha, os caras estão conspirando ali". Tem uma coisa meio doida, e isso me incomodava, ficava analisando isso, mas agora sou um cara que não anda tanto no campus, não frequento os bandejões mais... Hoje dá pra ver que tem uma mudança aqui. Hoje já tem os grupos de negro. Isto é mudança, sim; isto não é qualquer coisa, não.

Fela, diferentemente das outras histórias aqui reveladas, é um servidor que transitou tanto nos espaços do trabalho como também na sala de aula como estudante da USP. Essa experiência dupla lhe permite trazer uma carga de informações importantes para entender o quão profunda é a compreensão de seu corpo negro. Inicialmente, como Lutalo, ele concorda com a ideia de que não existem diferenças entre ser negro na USP e ser negro fora da USP. Tudo está implicado e tem relação, como já vimos, com práticas relacionadas ao racismo - ou racistas, como trouxe Lutalo. Ao ocupar a sala de aula, Fela não se desprende da sua ótica como servidor, já que sua fala é carregada de um tom questionador sobre as questões do seu corpo negro no espaço de trabalho e na sala de aula, onde sua presença é sinônimo de estranhamento. Seu relato é marcado, assim, pelo evidente desconforto na relação que ele possui com o professor que, ao vê-lo na sala de aula, desconfia da possibilidade de um servidor estar na sala como aluno. O desconforto que se faz presente em sua narrativa invoca uma pergunta: como o "pretinho da biblioteca" conseguiu estar na lista de chamada? Nesse sentido, esse olhar do professor branco em relação ao aluno negro faz parte de uma das molduras que existem também no ensino superior, em que a sensação de "piração" é, na verdade, uma autodefesa criada pelo corpo ao se sentir ameaçado - leia subestimado - pelo professor.

Outro ponto levantando por Fela é o envolvimento do negro com o próprio negro. Ele chama de "auto monitoramento" o encontro de estudantes negros pelo território da USP, 
onde, ao ser observada a aglutinação de sujeitos negros na condição de estudantes, é suscitado um sentimento de "pânico", "incômodo" e "inquietação", como se não estivessem acreditando no que veem do outro lado do espelho. Esse comportamento pode ser explicado pela "marca da diferença" (SOUZA, 1983, p.26) que separa o negro do branco, mas que, no caso do relato de Fela, aparece no nível de comportamento externos e internos à própria população negra. Esse processo ocorre na medida em que o negro "reedita essa desigualdade, introjetada no seu universo psíquico, quando, ao conviver com outro negro, seu semelhante, o reduz ao ritual de separação" (Ibid., p. 27). Assim, o sentimento de "auto monito ramento" altera o eixo do convívio negro - o encontro da negritude -, passando de um fator positivo para um fator negativo.

No final de sua fala, Fela sinaliza que a presença de estudantes negros (as) dentro da USP está mudando, sendo possível ver mais grupos de negros do que antigamente. No entanto, ainda é uma realidade o discurso que posiciona o corpo negro como exceção ou, como a professora Akilah diz, como descolado ou híbrido:

Eu me acho um híbrido. É assim que eu consigo me definir: um híbrido. Porque eu não me encaixo em lugar nenhum. Um híbrido não reproduz, e eu acho que não consegui reproduzir nada. É, isso às vezes me deixa um pouco frustrada, porque quando você pertence a um grupo teórico, você vai deixando descendentes. Eu não sou nem x, nem y, nem h. Acho que dá para fazer um curso crítico sem ficar presa a esses três, mas ao mesmo tempo, quando você abre muito, você não cria um séquito. Não estou deixando descendentes lá na USP, não tô deixando laboratório, nem nada disso. Eu classifico o processo como sendo muito solitário. Muitas vezes me sentia muito só, outras vezes me sentia culpada, com a síndrome de sobrevivente, de que só eu sobrevivi.A sensação de que você tá em um lugar que você não deveria estar... O que você tá fazendo nesse lugar que não era para você estar? É uma coisa que estou trabalhando na terapia há anos, porque é uma coisa complicada você não pertencer a lugar nenhum. Então eu sou um híbrido, não pertenço a lugar nenhum. Eu fui uma exceção. Ao mesmo tempo que eu não quis ser um símbolo,eu não quis ser um Martin [Martin Luther King].É uma coisa, muito, muito pesada para carregar nas costas. Eu não quero esse símbolo, eu não quero esse Martin.A questão é: eu apoio o que vir, mas não faço parte dos movimentos negros. Conheço muita gente e já fui em uma discussão e outra, mas a questão negra na universidade não me amarrou, não me pegou pelo pé. Então, o que mais me pegou é que sou uma servidora pública, tenho que lecionar, tenho que fazer o trabalho de extensão e tenho que fazer pesquisa. É isso. Nada mais. Mas eu me acho um híbrido, eu sou uma exceção. Eu tenho plena noção disso, que sou uma exceção. Eu sou um ponto fora da curva, um bicho estranho. 
O conceito de hibridismo está atrelado ao discurso biológico sobre a vida e a situações em que se tem a mistura de progenitores de espécies diferentes ${ }^{46}$, de modo que ser composto por elementos diferentes torna algo ou alguém deslocado das normas e padrões que estão presentes em determinados espaços. No relato acima, a professora universitária Akilah faz uma analogia com essa mistura, considerando-se um híbrido nos espaços acadêmicos por "não se encaixar em lugar nenhum". Sua trajetória como mulher negra acadêmica foi, em sua leitura, marcada por decisões epistêmicas desprendidas, já que, ao contrário de outros professores, não se centralizou em um grupo teórico para exercer seu debate crítico. Essa decisão tem consequência no mundo da academia, pois, se de um lado sua autonomia permite uma circulação maior em vários campos teóricos; por outro, limita possibilidades futuras de ter "descendentes" 47 .

Para a professora Akilah, a trajetória acadêmica foi uma caminhada escolhida de forma solitária. Sentia-se só, sem laboratório ou disputas de poderes que configuram o mundo intelectual universitário, havendo apenas ela e sua orientação. Culpada, a professora também nos fala sobre a "síndrome do sobrevivente", que envolve pensar que apenas ela sobrevive em um território onde há uma baixíssima presença de professores negros, gerando a sensação de que ela não deveria estar ali. Ser uma exceção, para a população negra, pode ser entendido, então, como "uma identificação ostensiva com os interesses, os valores e os modelos de organização da personalidade do "branco" (SOUZA, 1983, p. 23).

Apesar de a professora reconhecer a importância do debate, tendo a oportunidade, inclusive, de estar em alguns espaços, ela recusa a ideia de ser um Martin Luther King na questão racial, pois prefere estar à frente de outras discussões que "amarram" sua participação dentro da universidade pública. $\mathrm{O}$ fato de a professora não participar diretamente dos debates relacionados ao negro acaba sendo um rótulo de proteção à sua imagem dentro da academia, uma vez que é comum reduzirem - até mesmo estereotiparem - a imagem do professor negro acadêmico, associando-o unicamente ao debate racial, de modo que a escolha da professora representa uma forma de ampliar esse olhar no sentido de uma resposta: sim, sou negra, mas não estou no movimento negro.

A esse respeito, vemos uma perspectiva diferente com o professor Nassor. Segundo ele, que também tem um envolvimento indireto com o movimento negro, a partir do

\footnotetext{
${ }^{46}$ Segundo o dicionário <michae lis.uol.com.br/>. Acesso em 10 mar. 2019.

47 Nesse caso a professora se refere a uma continuação epistêmica por parte de orientandos, baseada na defesa conceitual de algo criado e trabalhado ao longo da vida acadêmica de u m(a) professor(a).
} 
momento em que você é negro dentro da universidade, você acaba assumindo um espaço político:

Eu acho que agente acaba assumindo muitas vezes um espaço que é político também. De acordo com os anos que a gente tem aqui na universidade, você acaba tendo cada vez mais noção disso. Você é visto muitas vezes como estudante negro, como aquele que participa, que faz parte de um outro grupo...Essa posição faz com que você tenha que amadurecer politicamente para sobreviver dentro desse espaço, dentro desse sistema. E você acaba tendo que ter consciência de sua posição aqui dentro também. É claro que, dentro da universidade, não é somente dessa forma que você acaba amadurecendo politicamente.É muito fácil também dentro desse espaço você acabar esquecendo, invisiblizando esse tipo de história, de narrativa, e assumindo um ideal branco, recusando esse tipo de discussão. Eu acho que, com certeza, quem faz isso cria outros traumas ao assumir esse espaço, mas é claro que existe possibilidade para tudo isso.

De acordo com a fala do professor Nassor, essa função política, atrelada obrigatoriamente ao corpo negro, é adotada como uma forma de sobrevivência em um território universitário. O "sistema" a que o professor se refere é aquele em que as relações sociais são marcadas pela clivagem racial(SANTOS,2012), que o faz, mesmo estando na posição de professor, amadurecer para responder politicamente as diversas práticas que atingema sua vida.

Se, por um lado, temos professores que estão indiretamente envolvidos com o movimento negro, temos Nyota que, ao contrário, tem uma relação incisiva com o debate relacionado às políticas para a população negra dentro da universidade. Ela se intitula como "servidora negra ativista":

Eu sou uma servidora negra ativista e isso faz a diferença e, de uma forma limitada, traz e abre a discussão racial nesse território. Meus colegas brancos, os meninos da pós-graduação, falam pra mim: "Pô, Nyota, fui em tal lugar e só tinha branquinho, Nyota". Então aflora essa discussão, mas não é isso.Isso é uma gota d'água no oceano.A questão tem que ser ampla; não pode ser pontual.Esta é a nossa luta.

Aqui a servidora fornece, ao ser perguntada sobre o que é ser negra na USP, algo além da individualidade. Suas palavras abordam o campo coletivo, o campo da luta comum. Para Nyto, ser uma servidora negra ativista faz "a diferença" no território da USP, já que a ação diária gera não só uma compreensão individual sobre a população negra, mas também se reflete em todos os sujeitos, negros ou não negros, que estão ocupando o mesmo espaço e se relacionando nele. A saída das pessoas negras da invisibilidade acarreta, assim, um 
movimento de saída da inércia da democracia racial, pois uma das consequências da presença de uma mulher negra militante é a provável criação de uma agenda diária de debates até para aqueles que não são propositivos em pautas do movimento negro.

Nesse sentido, a participação no movimento negro revela uma distinção importante entre ser,assumir-se e considerar-se negro(TEIXEIRA, 2003), uma vez que é o movimento ne gro que faz assumir,em caráter definitivo, a ideia de ser negro, tendo sua "conscientização" através de leituras e/ou da militância(TEIXEIRA, 2003). Nyto reconhece em sua fala que iniciar o debate ainda é muito pouco pensando em toda a discussão racial, mas é interessante por retomara importância da representatividade negra em determinados espaços para a sinalização do racismo.

Como Renato Emerson Santos (2012) pontua, entendemos que o racismo é uma ideologia que organiza experiências e comportamentos diferenciados para a população negra, sendo "um fator determinante da violência, pois estrutura condições adversas que determinam o processo de exclusão e desumanização da população negra" (SILVA; CARNEIRO, 2009, p. 22). Essas experiências e violências diferenciadas e selecionadas pelo racismo estão presentes nas narrativas reveladas pelos(as) servidores(as) e estudantes negros(as) da universidade. Como já revelado em algumas falas, estar na universidade não resulta em uma proteção das questões que assolam a população negra fora dos muros do campus. "Ser negro na USP é ser negro no Brasil”, diz Lutalo. Por isso, decidimos fazer uma escuta cuidadosa no que diz respeito aos estranhamentos provocados pela ideologia racial nos seus diferentes níveis de violência. Assim, a partir dessa análise, interpretaremos e reconheceremos as problemáticas que ainda recaem sobre os sujeitos negros que ocupam o território da Universidade de São Paulo. 


\subsection{O racis mo nas relações entre indivíduos}

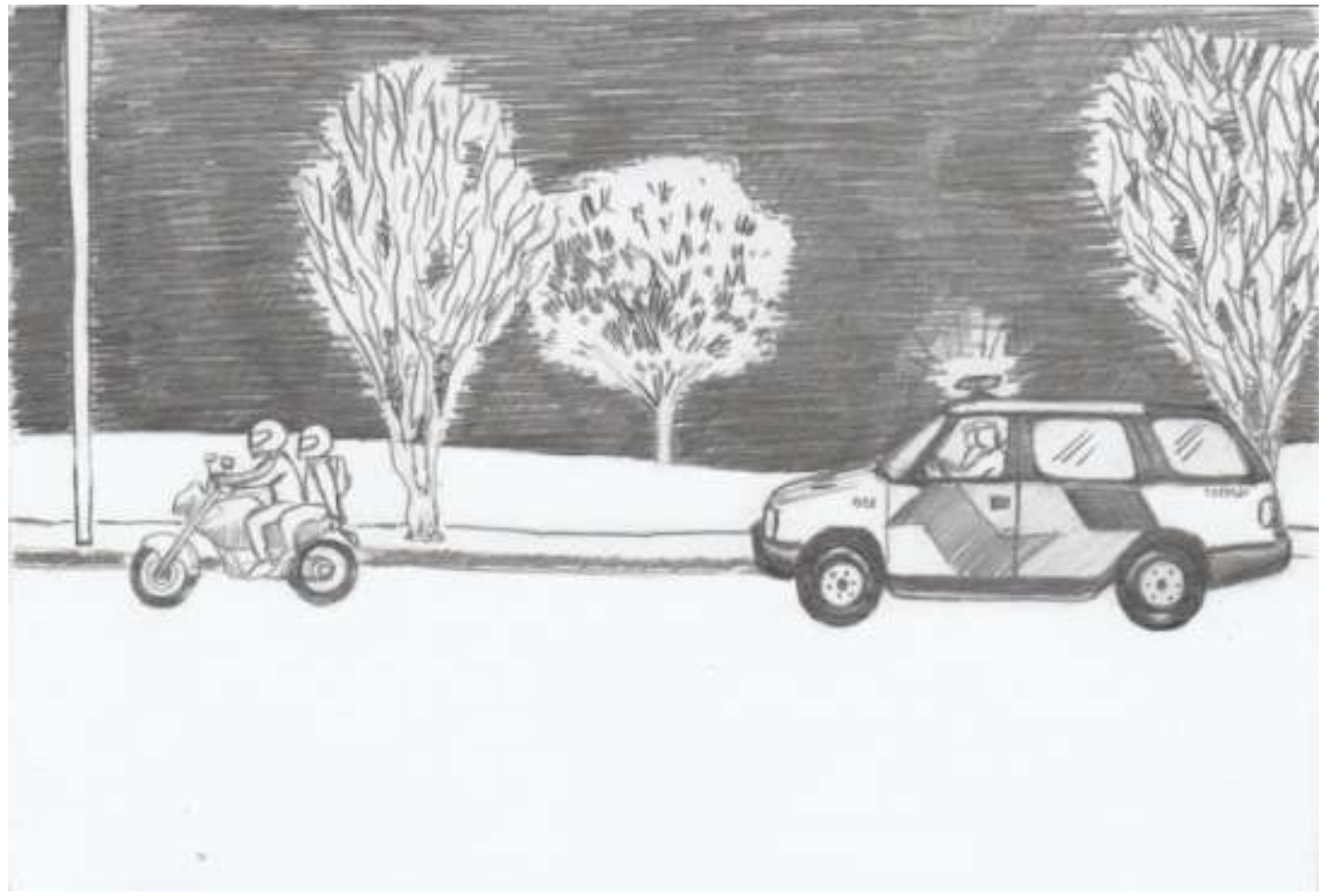

Figura 8-Suspeito Padrão.

Créditos: Isadora Almeida Simões (2019)

Então, meu filho estava fazendo um curso para poder prestar o vestibulinho da ETEC, lá em Pinheiros, e aí eu fui buscá-lo. Na volta, como o trajeto é bem mais prático, mais fácil e rápido por dentro da universidade, eu entrei nela e quando eu passei pelo CEPE-USP tinha uma viatura descendo. Quando os policiais viram dois negros em cima de uma moto, à noite, dentro da universidade, eles fizeram retorno e vieram atrás. Eu sei que eles pediram para eu parar umas duas vezes e eu não parei porque aquele pedaço estava muito escuro. Eu continuei na velocidade que tava,sem acelerar, mas continuei, andando uns $50 \mathrm{~km} / \mathrm{h}$,sem demonstrar desrespeito e nada.Fui parar lá em cima, perto da Farmácia, que era mais claro e tinha um ponto de ônibus mais próximo e tal.A hora em que eu parei a moto o meu filho falou "Pai, eles estão xingando", aí eu falei: "Faz o seguinte: desce da moto devagar, dá a volta por trás de mim, e fique atrás de mim". Aí ele desceu da moto, deu a volta, ficou atrás de mim, com eles gritando. Tirei o capacete e falei para eles que trabalhava dentro da universidade, que não tinha necessidade nenhuma de les estarem agindo aquela forma. Mandei, né? [...] Aí o policial pegou e falou para mim: "Nós estamos fazendo nosso trabalho". Aí eu falei para ele:"Meu, o seu trabalho é xingar? Não tem lógica você ficar xingando a gente, não tem motivo nenhum pra isso". Aí eles deram uma geral em mim, e quando eles foram dar uma geral no meu filho eu avisei que ele era de menor, que não achava correto, mesmo assim, eles deram uma geral nele.[...]Eu fiquei reforçando em vários momentos que eu era trabalhador da universidade, que meu filho era aluno da universidade, da Escola de Aplicação. 
Eu fiquei muito preocupado. Eu acho que ele nunca tinha passado por isso. Ao mesmo tempo, a gente quer proteger,né? Aí você fica morrendo de medo.Usei muito daque le argumento de que eu era trabalhador[...]Eu sei a forma como os caras agem, eu sei a forma como eles vão abordar você, a hora de pedir o documento, a hora de pedir para você abrir a pernas, para dar as respostas. Não são coisas tranquilas, são coisas bem agressivas... O meu medo era do meu filho. Eu acho que isso ajudou eu ficar insistindo tanto nisso, que eu era trabalhador e tal, que era da universidade, que meu filho estudava aqui.

O relato do Lutalo representa uma história muito comum para a população negra: a que está ligada à violência policial ${ }^{48}$, materializada, nesse caso, pela abordagem feita com o servidor e seu filho. Declaradamente, a postura da polícia que estava presente ${ }^{49}$ no campus do Butantã foi de iniciar uma perseguição ao ver dois negros em cima de uma moto por ser a forma como se dá a construção das relações raciais no Brasil, em que o negro é colocado socialmente como o principal suspeito ${ }^{50}$. Em razão da experiência acumulada quanto a abordagens policiais, Lutalo percebeu que essa situação poderia colocar seu filho em perigo. Assim, por conhecer o território da USP, o servidor toma a decisão de apenas parar a moto em um espaço seguro.

Outra estratégia destacada pelo servidor foi a de repetidamente comprovar a sua vinculação e a de seu filho com o território da USP. A insistência em declarar sua ligação com a universidade veio principalmente com o receio de acontecer algo com o filho e, por isso, foi uma forma de proteger a vida do garoto, levando inclusive o servidor a posicionar o seu corpo à frente do jovem estudante no momento do enquadro. Talvez o jovem nunca tenha passado por essa situação, mas a partir daquele momento é notório que o filho de Lutalo seria afetado pela mesma violência sofrida por ele no passado.

\footnotetext{
48 Em 2014, o Departamento da UFSCar realizou um trabalho, coordenado pela professora Jacqueline Sinhoretto, no qual foi feita uma análise da desigualdade racial na segurança pública de São Paulo, com foco na letalidade policial e nas prisões em flagrante. O trabalho desenvolvido pelo Grupo de Estudos sobre Violência e Admin is tração de conflitos da UFSCar(GEVAC) analisou os resultados das abordagens e das demais ações da polícia sobre os distintos grupos étnicos-raciais, revelando que os negros, especialmente os jovens, são as maiores vítimas de morte praticada por policiais $(61 \%)$. Nesse sentido, o resultado das ações policiais reflete a desigualdade racial na segurança pública, já que as ações policias vitimam três vezes mais os negros do que os brancos, quando consideramos a proporção entre branco e negro na população paulista.

49 A Policia Militar(PM) está presente de forma ostensiva no campus e em conjunto com a Guarda Universitária desde 2011, depois da morte de u mestudante da FEA chamado Felipe Paiva.

50 Silva e Carneiro (2009), em seu trabalho sobre a violência racial, fizeram um importante levantamento histórico de interpretações que acarretaram o estereótipo que posiciona o negro como suspeito.A partir de um estudo da antropologia criminal de Nina Rodrigues e dos códigos penais, o trabalho concluiu que a existência de políticas criminalizadoras no pós-abolição transformaram o negro no principal alvo de repressão policial.
} 
Ser observado com desconfiança pela segurança, passando por momentos de constrangimento, foi um aspecto bastante presente na fala do estudante Yerodin, quando perguntado sobre ter passado por algum preconceito racial dentro da USP:

Com certeza. Por parte de seguranças, né? Seguranças que insistem que você se identifique, e às vezes, você, no caso eu, percebo que ele olha para mim, mas não olha pros outros na questão de você ir lá falar que é você. Isso aconteceu umas vezes. Tem uma aula que estava fazendo no ICB, e aí o cara implicou que eu mostrasse a carteirinha. Eu estava na aula e saí vinte minutos,daí quando eu voltei ele pediu a carteirinha. E eu falei: "Pô, você não me viu aqui não, cara? Acabei de passar aqui!" E há também os olhares, que não sei né, não vou perguntar, mas percebo olhares em que estou sendo observado, principalmente por parte dos funcionários.

A situação indicada pelo Yerodin mostra que, mesmo ocupando a sala de aula na posição de estudante, o segurança do ICB desconfia de sua presença no espaço, exigindo que mostre a carteirinha de registro, chegando inclusive a criar um avesso de olhares, pois a mesma situação que fez o estudante questionar se o segurança não havia notado sua presença em sala foi a que provocou a sua desconfiança. A observação, no caso do segurança, não foi baseada na tutela, mas na ideia de perigo e inadequação do corpo negro em relação àquele espaço, em que um negro estudando no ICB cria o incômodo da dúvida. Esse olhar será pontuado de forma negativa pelo estudante quando ele sinaliza que reconhece ser observado constantemente por funcionários da universidade:

Caso semelhante aconteceu com Nassor, quando ele era estudante:

Quando eu era aluno, no primeiro ou segundo ano de graduação, eu tinha concorrido e solicitado uma bolsa, e consegui uma bolsa na sala de informática, como monitor. Aí marcaram "Vem aqui amanhã, às 8h da manhã, que aí você começa". Beleza. No outro dia eu cheguei lá pontualmente às $8 \mathrm{~h}$ da manhã, e os funcionários ainda estavam chegando. Aí fui lá na sala de informática e não vi ninguém, estava tudo mais ou menos escuro. Entrei na sala e fiquei aguardando chegar algum funcionário. Aí chegou uma funcionária, que me viu lá e, muito brava, foi abrir a porta e disse: "O que você tá fazendo aqui?" Eu respondi: "Ah, eu sou bolsista aqui, estou aguardando um funcionário que trabalha aqui". Acho que tinham esquecido a sala aberta.E ela falou de um jeito que era como se eu não fosse funcionário, como se eu não fosse estudante, mas como se eu fosse realmente um intruso; alguém que por caso estava andando e entrou numa sala, né? Depois que eu falei que era aluno e tal que ela mudou o modo de se portar, de se dirigir a mim naque le momento.

Em outros, andando pela unidade - na época eu tinha dreads - chegavam estudantes me abordando, perguntando se eu tinha beck, se eu tinha maconha. 
Ao relatar sua vivência enquanto aluno da universidade, Nassor revela semelhanças em no que se refere às reações de estranhamento das pessoas ao verem um negro ocupando espaços onde normalmente não há pessoas negras. A reação da funcionária reproduz a forma como se estrutura as hierarquias raciais no Brasil (SANTOS, 2012), anulando a presença de Nassor como trabalhador e estudante ao subalternizá- lo como um "intruso". Há uma mudança de conduta por parte da funcionária apenas quando ele - como ocorreu com Lutalo comprova seu vínculo com o território da USP, de modo que ela passa a ser mais permissiva quanto a sua presença naquele espaço. Outra situação que ele revela em sua fala é a que envolve o fato de usar dreads, em que sua estética negra parecia ser interpretada por outras pessoas a partir de estereótipos de traficante ao ser sempre abordado como um possível fornecedor de entorpecentes.

Quando perguntado sobre a relação do seu corpo, enquanto professor e funcionário da USP, com o território, e sobre já ter sido vítima de algum tipo de discriminação racial, ele revelou duas histórias, em que a primeira delas é muito semelhante com a violência sofrida por Lutalo. A diferença é que, ao invés do filho, foi a esposa que passou por uma situação de constrangimento policial junto com ele:

Já teve situações que, ao sair ali perto da São Remo, para encontrar minha esposa, fui parado pela polícia. Uma vez revistaram a gente e passou inclusive uma aluna minha, que me pegou lá nas paredes, com as mãos nas paredes: "Não! Professor, oi" e eu disse "oi", sendo revistado pelos policia is.

Outro momento de estranhamento dentro da USP se deu em seu ingresso como professor, quando sentiu o "choque" das crianças do colégio universitário ao vê-lo como professor:

Tem uma história interessante também.Quando eu comecei a dar aula, eu dava aula pra molecada, e são poucos professores negros. Lembro que logo que eu entrei, no primeiro ou segundo ano, tinha um aluno pequeno, devia ter 8 ou 9 anos, que deve ter me perguntado umas cinco vezes se eu era professor.Ele olhava assim e dizia: "Você trabalha aqui?", "Ah... Eu sou professor"."Você é professor do quê?"... "Mas você trabalha aqui?"[risadas]. Eu acho isso muito interessante porque tem algo ali que é a inconsciência de uma criança, mas tem algo ali que ela aprendeu socialmente e visualiza isso no seu cotidiano, como quais são os espaços onde ela vê pessoas negras atuando e quais são os espaços que não têm pessoas negras atuando. Provavelmente, para esse aluno era uma novidade ver um professor negro naquele espaço 
Como o professor pontua, existe uma dimensão racial que vai além da inocência do mundo infantil, pois está introjetada na sociedade, sem filtro de idade, e atua como um instrumento social de dominação da população, um constructo ideoló gico (QUIJANO, 2007), que faz com que inclusive uma criança dialogue, de forma sutil, com as contradições provocadas pelo racismo.

Esse não é um caso isolado: a professora Akilah também trouxe em sua narrativa uma situação semelhante à que ocorreu com Nassor; porém, por ser uma mulher negra dentro da Universidade de São Paulo, há contornos em sua história que a tornam diferente daquela evidenciada pelo gênero masculino. Como Nassor, a professora teve uma parte de sua trajetória como estudante de graduação. Ao perguntarmos sobre o estranhamento quanto a ser uma mulher negra dentro da USP, ela nos responde:

Acho que a própria alcunha de Pérola Negra já foi um estranhamento. Entraram 160 [alunos], 80 no noturno. Entrei no noturno; faltavam negros. Era só a Mara e eu, só nós duas, mas no noturno era só eu. Eu via umas coisas... Tinha uma professora, que acho melhor não dizer o nome, descendente de italiana, que dava umas aulas estranhíssima se no meio da aula ela falava assim durante a chamada: "O que você tá fazendo aqui, menina? Você é tão linda, exótica... Vai ser atriz da Globo, vai fazer teatro, dança... Você é tão exótica!". E esse adjetivo me perseguiu muito, porque eu era muito assim, de produzir meu visual, de ter minha fantasia, ter o meu visual.Eu não gostava de cinza, eu não gostava de jeans. Eu sabia costurar um pouco, então eu fazia minhas roupas. Eu fiz com meu cabelo tudo que pude: moicano,fiz o diabo... Fazia umas roupas minhas e usei muitas bijuterias. Usava molhos de colares, pulseiras que vinham até aqui... Então, quando a acadêmica não consegue te enquadrar, você vira exótico. Essa era uma coisa que me incomodava bastante: "A Akilah é exótica".

Como já abordamos, ser chamada de Pérola Negra está relacionado a uma história única sobre o sucesso negro, que leva as referências negras a serem reduzidas apenas a personalidades artísticas ou do ramo esportivo; porém, Akilah traz algo novo ao falar sobre a questão do exotismo do seu corpo no relacionamento professor-aluna em sala de aula. Ter um visual que sai do padrão, com roupas coloridas e únicas, construídas por ela mesma, incomodou a professora a ponto de ela interromper a aula para focar no corpo da jovem Akilah que, perante a docente, foi enquadrada fora do modelo do curso. Para a professora, a aluna deveria optar por outros cursos por ser "linda" e "exótica", mas em momento algum pontuou a criatividade estilística como fator técnico, pois seu comentário limitou a aluna novamente a uma visão estereotipada do corpo negro como forma de sucesso.

Ao ser perguntada sobre situações de preconceito, Akilah continua: 
Eu vivenciei o racismo mesmo, que é aquela coisa de secar o outro e tal, na minha vida afetiva e emocional. Na minha re lação com os homens. Ai, tem muito casos, foi complicado. Eu era mais um prêmio a ser conquistado para colocar no colarzinho do fulano, sabe? Mais uma pedrinha pro fulano. Eu toda bobinha, apaixonada e interessada e o sujeito vinha, chegava perto, tinha o relacionamento e, quando eu menos pensava,ele ia embora.Logo ele comentava com outro "Eu consegui ela, você não conseguiu" [...]. Foi uma extrema frustração da minha parte encontrar homens que,apesar de todo discurso de esquerda, do marxismo bem pesado nos anos 80 na universidade, viam a mulher como equivalente a nada. Tive muitas frustrações na minha vida afetiva emocional, sexual, com os homens.

[...] Tinha umas coisas, umas situações curiosas. Eu estava no CEPE-USP, onde frequentei muito e ia muito nas piscinas. Eu estava no vestiário feminino me trocando e aí apareceu uma mãe com uma criança, uma mulher branca com uma criança branca. Estava lá me trocando e a criança de uns 3, 4 anos,vem chegando,vem chegando... E chegou bem perto de mim e fez assim [a entrevista passa os dedos sobre minha pele e ri].Ela passou a mão nos meus braços e disse: "Mãe, porque ela é assim e eu sou assim?". A mãe não sabia onde enfiar a cara [risadas].Era uma criança brasileira, vivendo aqui, que nunca tinha chegado perto de um negro, olhando pra mim como se eu fosse um ser de outro planeta. Tinha visto na TV, né? Você fala assim "gente, tem gente que é criado aqui no Brasil que nunca teve contato com negro, não tem contato, não sabe como é".

E outra vez, nesse mesmo vestiário, aconteceu um caso com outra criança, que chegou perto da mãe e falou assim "Mãe, porque essa veio e a nossa ficou lá em casa?"[risadas]. "Porque essa veio"... "Para com isso, menino", disse a mãe, que deu uma bronca na criança. Se é a babá ou a empregada dele, deve ser negra... "Porque essa veio, porque ficou em casa..." [risadas].Essas coisas malucas...

A primeira situação que a professora expõe está vinculada a sua afetividade e ao seu emocional. Seus relacionamentos marcaram de forma profunda suas vivências enqua nto estudante universitária negra, a ponto de se sentir como um objeto a ser conquistado pelos homens. Ser tratada como objeto não é uma característica que se limita à mulher negra, mas envolve sobretudo as mulheres negras, de modo que concordamos com Pacheco (2013) quando pontua que as experiências afetivas das mulheres negras não podem ser (des)corporificadas, pois há dentro desse grupo forte influência de fatores raciais e de gênero na regulação das escolhas afetivas:

Há uma representação social baseada na raça e no gênero, a qual regula as escolhas afetivas das mulheres negras. A mulher negra e mestiça estaria fora do 'mercado afetivo' e naturalizada no 'mercado do sexo', da erotização do trabalho doméstico, feminilizado e 'escravizado'; em contraposição às mulheres brancas, que seriam, nessa elaboração, pertencentes à 'cultura do afetivo', do casamento, da união estável'.(Ibid., p. 25) 
O segundo episódio apresentado pela professora diz respeito a uma situação semelhante à ocorrida com Nassor; no entanto, a situação de Akilah acontece em um espaço fora do ambiente de trabalho, no CEPEUSP, um espaço de lazer. Dentro do vestiário, se não bastasse uma situação, foram dois os momentos em que o racismo se fez presente de alguma forma, em que a reação das crianças nada mais foi do que uma forma declarar as contradições impostas pela falsa democracia racial, estando diretamente relacionadas ao constructo social que localiza o ne gro em situações estereotipadas. O segundo em caso, em especial, é um claro exemplo da ótica de uma criança branca em relação à mulher negra, vendo-a unicamente como empregada. Contudo, o primeiro caso é ainda mais incomum para a professora, evidenciando o fato de que no Brasil, particularmente em São Paulo, há crianças que nunca tiveram contato com pessoas negras, o que nos faz pensar que, além dessa constatação, a criança "que nunca chegou perto" de uma pessoa negra provavelmente nunca teve contato com uma pedagogia que a aproximasse de outros grupos que não o dela.

A visão da sociedade sobre o corpo da mulher negra também aparece diretamente na narrativa da estudante Baduc:

Uma vez eu estava no vão da História, com um amigo negro. A gente era de uma época que tinha umas mesinhas ali no vão... A gente sentava ali e conversava. Um dia a gente tava conversando de boas - devia ser meu primeiro ou segundo ano, bem no início da graduação - e passou uma senhorinha branca vendendo trufas - eu acho que ela vende até hoje por aí. Ela parou e disse "Oi, tudo bem?Vocês não querem comprar uma trufa?"; "Não, obrigado, hoje não"... E aí ela insistiu e virou pro meu amigo[suspiros fortes] e falou assim: "Compra pra ela. Não vai comprar uma trufa para essa morena linda? Olha esse corpo, olha tá tudo aí, você pode pegar”. Aquele momento foi marcante, porque uma mulher que não conheço, uma mulher idosa e branca, se sentiu no direito de vir me oferecer como mercadoria para meu amigo negro, sabe?Nossa!Das situações que não são muito sutis, a mais direta foi essa...

Essa situação com a estudante Baduc nos faz lembrar o que Gonzales (1982) explica sobre a visão da mulher negra como objeto sexual na sociedade brasileira, que leva a episódios como esse. Um olhar despreparado poderia entender o comentário da senhora como um elogio, mas, na verdade, trata-se de uma violência direta do racismo contra a existência da estudante como mulher negra.

Outra fala muito importante foi a da servidora Karassi. Como outras personagens, ela, uma mulher negra, traz uma carga sobre as diferenças na seleção do crescimento funcional dentro da universidade: 
Eu vivi isso no meu trabalho.Quando tinha as avaliações, desempenho de carreira, como é chamado na Universidade de São Paulo, eu poucas vezes consegui a avaliação por mérito, pois eram geralmente as branquinhas, com olhos claros e amigas da chefia, que conseguiam. Eu sempre fui uma pessoa bastante crítica e isso me fez não participar de algumas coisas, né? Nesse critério de avaliação...Quer dizer a verdade, eu sou um peso no meu trabalho.Então eu perdi muita coisa por conta disso, mas sou consciente disso e pra mim foi importante falar a verdade.

Apesar de Karassi se justificar, relacionando a sua não participação nas entre vistas de desempenho com seu posicionamento crítico no trabalho, a servidora também compreende que existe um perfil de pessoas avaliadas por mérito: brancas e de olhos claros, o que nos deixa uma dúvida: ela seria um peso simplesmente por ser crítica ou ser crítica e uma mulher negra cria um ranço maior e a torna um peso na seleção dentro da universidade? O que podemos responder é que, por mais capaz que a mulher negra seja capacitada, ela é, muitas vezes, preterida no espaço de trabalho. Não à toa, era comum vermos nos anúncios de vaga de emprego o requisito "boa aparência", que, para Gonzales (1979, p. 14), trata-se de um código cujo "sentido indica que não há lugar para a mulher negra".

A servidora também relata um outro caso:

Uma pessoa da limpeza, uma vez, por causa de uma fruta, foi bastante perseguida. A gente sabia o que estava por trás, pois se fosse qualquer outra pessoa teria deixado passar. Ela pegou uma fruta e escondeu no armário. A gente deu um jeitinho e fomos avisá-la: "Olha, não é nada, mas isso pode te causar um grande conflito. Vê se você consegue por essa fruta no lugar para não pesar muito para você". E ela conseguiu colocar a fruta e tal, mas isso porque a gente contornou a situação. Mas estavam indo para cima de la tipo "Eu sei quem foi”. Não conseguiram achar, não tiveram provas, mas era uma carta marcada.Infelizmente, é assim que funciona.

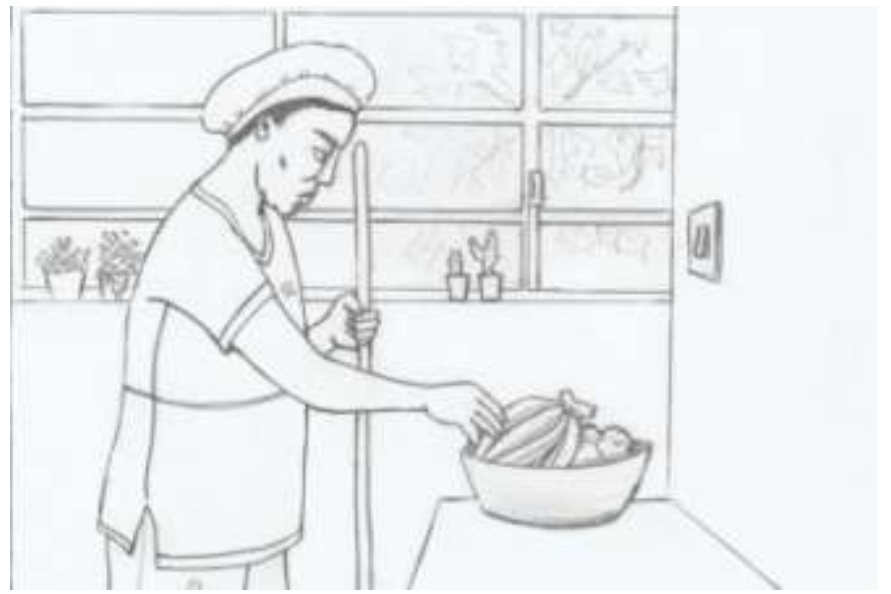

Figura 9 -Mãos Negras.

Créditos:Isadora Almeida Simões (2019) 
"Era uma carta marcada" - leia-se demarcada pelo padrão que liga as características físicas a um suspeito padrão. Entendemos que, pela pergunta ter sido direcionada aos casos de racismo, a pessoa que estava sendo pressionada no relato de Karassi provavelmente era negra. Financeiramente, uma fruta não possui um peso relativo, mas simbolicamente existia uma razão para todo o conflito, que viria a conformar-se em uma situação de desconforto e humilhação para aquela pessoa.

Ser marcada em um espaço majoritariamente ocupado por pessoas não negras possibilita, assim, momentos de desrespeito, como o que ocorreu com Nyota:

Uma vez foi um pesquisador aqui, escrotinho, que ocupa altos cargos até hoje.Ele era da Química e argentino, eu acho.Ele falou em um jantar, em que chegou conversando comigo, me apresentando. Em uma conversa entre ele e colegas, ele disse: "Você sabe porque você está aqui, que isso não é comum entre os funcionários,né? Você estar aquî". Aí eu disse "eu sei, professor, eu tenho consciência disso".

Nyota concluiu reforçando a questão do racismo:

Tem uma outra questão: primeiro,o racismo não é sutil e, depois, eu questiono muito essa pergunta, porque não importa se o sujeito sofreu, se o grupo sofre, né? O outro sofrendo, você é naturalmente a vítima, existe essa correlação, porque - eu tô te falando isso de uma forma muito carinhosa tem muitos brancos que já perguntaram pra mim: "Ah, você tem cara de classe média.Como você sofre racismo?". Como se o preto que estivesse dirigindo automóvel, como uma amiga,que sofreu, foi abordada, mesmo sendo filha de policial civil, não sofresse.... É uma coisa pesada. "Classe média"“cara", "perfil de classe média". "ela é classe média!".Mas independentemente do nosso perfil nós sofremos racismo[..].

O desrespeito sentido pela servidora Nyota no jantar com o professor universitário é um relato das contradições em torno do ordenamento social racializado(SANTOS,2012), pois, a partir do momento em que são definidos os espaços a serem ocupados pelos negros, qualquer situação que fuja dessa normalidade é produto de situações como a relatada pela servidora.Essas situações são seletivas e não aleatórias, distinguindo os sujeitos que de fato experienciam e os que praticam o racismo,como exemplificado por Nyota. Uma mulher branca jamais sofreria a mesma abordagem que Nyota, pois o que está em jogo na fala do professor não era somente o machismo, mas também o racismo, que culminou em toda a circunstância relatada. 
O que foi revelado pela servidora esteve presente de alguma forma nas narrativas de todas as entrevistas feitas com servidores(as) e alunos(as) da Universidade de São Paulo.Ponderando as diferenças de tempo e de espaço ocupado dentro da universidade, essas narrativas se aproximam em vários momentos, o que demonstra que as vivências desses sujeitos são produto de uma estrutura social semelhante, que constrói, no campo do envolvimento com a USP, relações de tensões entre os indivíduos negros e os não negrosdentro do campus.

Entretanto,existe algo de especial na fala da servidora Nyota, sobretudo quando reforça seu entendimento sobre o racismo. Entendemos que, ao negar sutileza do racismo brasileiro, ela desconstrói todo um discurso esvaziado sobre a violência causada à população negra brasileira. Ao questionar também a ideia do racismo "individualizado", ou seja, aquele provocado e sentido apenas pelo indivíduo negro em dados momentos de sua trajetória, a servidora, novamente, levanta um questionamento necessário, pois, em sua perspectiva, a partir do momento em que ocorre uma ação racista contra um sujeito negro, todo um grupo (coletivo) também é agredido.

Essa noção de solidariedade dá margens para observação de diferentes níveis de cidadania(SANTOS,1996)por parte de alguns grupos e movimentos dentro da Universidade de São Paulo, que têm outro grau de consciência do que é ser negro e de como o racismo opera dentro do território da USP. Eles percebem, a partir de uma organização política negra, a relação existente entre a corporalidade, a individualidade e a sociedade para definir sua cidadania(SANTOS,1996), uma vez que esse tipo de organização produz movimentos territoriais de luta por direitos específicos dentro da universidade. Consequentemente, o significado marcado por essas territorialidades faz com que seja repensado o modo como o corpo negro é lido na USP, criando uma agenda provocativa sobre os problemas gerados pela falsa democracia racial.

Nesse sentido, como fruto direto dessas histórias reveladas e escutadas neste capítulo, a cidadania se torna, então, mais um dos caminhos para entender as transformações existentes no território da USP a partir da ótica do movimento negro. 


\section{CAPÍTULO 3 - A cidadania e a população negra da USP}

\subsection{Do movimento enegrecido para a cidadania completa}

O processo na participação no que entendemos como cidadania completa esta, para a população negra, em curso, graças ao movimento de organização negra que, desde o final da escravatura tem reivindicado a presença de sua corporalidade forma efetiva no território Brasileiro. Essa luta, foi desbravada de diferentes maneiras e características revelando sua diversidade e complexidade no ordenamento desse projeto de construção do direito pela/para a cidadania.

Existem múltiplas definições para o que chamamos aqui de movimento negro. $\mathrm{O}$ sociólogo Petrônio Domingues (2007) define movimento negro como sendo "A luta dos negros na perspectiva de resolver seus problemas na sociedade abrangente, em particular os provenientes dos preconceitos e das discriminações raciais, que os marginalizam no mercado do trabalho, no sistema educacional, político, social e cultura". Seguindo o mesmo caminho, o geó grafo Jonathan Marcelindo (2018, p.137), em seu doutorado intitulado de "Geografia, movimento negro e relações étnico-raciais: um dialogo necessário", irá nos fornecer seu olhar sobre o movimento negro como sendo "toda manifestação organizada por afrobrasileiro, com o objetivo de divulgar sua cultura, escrever a verdadeira história do Brasil, denunciar o racismo e a ele resistir e valorizar o home negro( pessoa humana), além de praticar de outros meios adequando à luta de um povo pela sua identificação para ser respeitado".

Apesar de áreas diferentes ambos os pesquisadores se aproximam do ideal de movimento negro como sendo ações ativas na sociedade que visam diferentes narrativas para essa população negra, com o intuito de seu respeito e valorização material e imaterial no território nacional. Nestes dois casos, tais ações possuem o cunho político-cultural, ou seja, caracterizam por desconstruir(demolir) a leitura marginalizada de um grupo em distintos espaços para sua conquista real, das problemáticas sociais que envolvem diretamente o corpo negro(a).

A afinidade étnico-racial também é marco nas duas leituras de movimento negro acima que, entendem a identidade atrelada a cidadania negra (GONZALES,1986). Essa mesma identidade não será apenas usada como elemento de mobilização, mas, também, de mediação política, sendo a 'raça' como um fator determinante na organização de um projeto comum ( DOMINGUES,2007). Essa mesmo fator de aglutinação que designa a proposta de 
identidade negra, irá respaldar à agenda soerguida pelas mulheres negras na construção do feminismo negro. Essa que, na década de 70/80 foi uma reivindicação histórica de emancipação político e identitário "que de acordo com sua particularidade buscou na trajetória de mulheres negras presentes na história ou no imaginário social, referencias identitárias que norteassem suas ações” (LIMA, 2011, p.1).

Entendemos que a definição de movimento negro, apesar de suas semelhanças, ainda não é consenso entre os pesquisadores/militantes (MARCELINDO,2018), cabendo ter um cuidado na abordagem desse assunto. Não pretendemos aqui fazer um aprofundamento das diferentes e complexas óticas desse processo de luta negra pela cidadania completa, mas, desenvolver um paralelo com as conquistas politco-culturais que, historicamente, atrelaram esse grupo marginalizado a uma geografia re-existência no território brasileiro/paulista. Como caminho para uma reflexão do que desejamos, iremos nos apoiar as proposta metodológica de DOMIGUUES(2007) que, a partir de um estudo sobre o período republicano(1889-2000), conseguiu trazer uma analise intrigante sobre a organização negra que desenvolveu, neste período, estratégias de lutas pela inclusão social do negro e a superação do racismo. O sociólogo divide a história do movimento negro em três grandes fase: Primeira fase do movimento negro(1889-1937); Segunda fase do movimento negro( 1945-1964) e a Terceira fase(1978- 2000).

A primeira fase é marcada pela pelo novo sistema político nacional que não assegurou profundos ganhos materiais ou simbólicos para a população que saia da condição de escravizado (DOMIGUUES, 2007). O fim da escravatura demarcou território corpo negro como já pontuado por VAINER(1987), fomentou uma condição para essa população de privações de direitos a partir de mecanismo de restrições de oportunidades, que, sem nenhum apoio institucional, não estariam em condições ${ }^{51}$ de resistir a livre competição com os imigrantes europeus ${ }^{52}$ (FERNANDES,2008). Neste contexto de restrição/exclusão da população negra, irá surgir movimentos de mobilização e aglutinação étnico-racial no Brasil que teriam como objetivo a re-leitura espacial do negro na sociedade. Os clubes, grêmios ou associações negras, terão nesse período, um papel importantíssimos de junção/aglutinação espacial desse grupo, interligando ao encontro do direito para lazer/recreações; destaca-se

\footnotetext{
${ }^{51}$ Florestan Fernandes (2008), também irá ressaltar que a população negra possuía poucos recursos, e esta redução de bens, fazia co m que muito raramente cogitasse em explorá-los em u m sentindo capitalista (o contrario do que acontecia com os emigrantes brancos).

${ }^{52}$ Inclusive, essa dificuldade em resistir no novo sistema, fez com que mu itos negros, apesar dos estigmas sofridos nas fazendas, optassem em continuar ou regressar para essas, entendendo ser no campo, onde poderia ter melhores oportunidades.
} 
nesta primeira fase do movimento pelo direito a cidadania, o surgimento da imprensa negra, que serão jornais produzidos pela/para a população negra, pensando em questões que envolvem as diversas perspectivas das ações político-culturiais dessa população e bloqueio de sua corporalidade no território.

Esses jornais ${ }^{53}$ enfocam os mais diversas mazelas que afetam a população negra no âmbito do trabalho da habitação da educação e da saúde, tornandose em solução concretas para o problema do racismo na sociedade brasileira. Além disso, as páginas desses periódicos constituíram veículo de denuncia do regime de segregação que incidia em várias cidades do país, impedindo o negro de ingressar ou freqüentar determinadas hoté is, clubes, cinema, teatro, restaurante, orfanato, estabelecimentos comerciais e religiosos, além de algumas escolas, ruas e praças publicas( DOMINGUES,2007,p.105).

Outra importante marca de luta pelos direitos nessa primeira fase, foi a fundação da Frente negra Brasília( FNB) em 1931, que, representou "a primeira organização negra com reivindicação mais declaradas"(DOMINGUES, 2007, p.106). A frente negra, foi uma entidade que, em menos de cinqüenta anos do fim da escravatura conseguiu pensar e desenvolver políticas de cidadanias profundas para a população negras, assim, em um considerável nível de organização, já mantinham escolas ( figura 9), construíram cursos de formação em política/ofícios, grupos culturais, fora um departamento jurídico e médico que cuidava especificamente da população negras. Se por um lado, institucionalmente, existia o sileciamento mortal para a recuperação/inclusão dessa população que, em mais de trezentos anos, se viu objetivadas por um sistema escravocrata, por outro, a FNB, reconhecendo as problemáticas existentes nesse processo de transição de sistemas econômico-politococultural, viu-se necessidade em oferecer oportunidades para essa população. $O$ depoimento de Marcio Barbosa no livro Frente Negra Brasileira depoimentos de 1988, sintetiza a relação entre o e contexto histórico e a população negra, ao mesmo que, traz o papel da FNB na desenvolvimento de políticas diretas para o(a) negro(a). Segundo BARBOSA (1998):

As condições de vida eram precárias. A Maioria era analfabeta, morava em cortiço e trabalhava em subempregos. Não houve políticas no país que visassem proporcionar aos descendentes africanos chances de conseguir uma bola qualidade de vida, ao contrário do que aconteceu com o imigrante. No aspecto de saúde, a situação era tão grave que previa-se o desaparecimento da população negra e umas das causas seria a tuberculose[...] A Frente Negra ofereceu, a essa população marginalizada

\footnotetext{
${ }^{53}$ Um dos principais jornais deste período foi o Clarin da Alvorada em 1924. Em 1931 co m a criação do Frente Negra Brasileira, surgirá outro jornal mu ito importante neste primeiro período que foi A voz da Raça.
} 
possibilidade de organização, educação e ajuda no combate à discriminação racial. Incentivou a conquista de posições dentro da sociedade e a aquisição de bens. Foi, sem dúvida, conservadora, expressava as pirações de negros de classe média e teve concepções políticas limitadas. Mas tentou dar aos afrobrasileiros condições de se integrarem à sociedade capitalista e conseguiu resposta popular[...]Configura-se como uma das grande mobilização negras no contexto urbano e sua trajetória é um capitulo importante da história do povo afro-brasile iro.

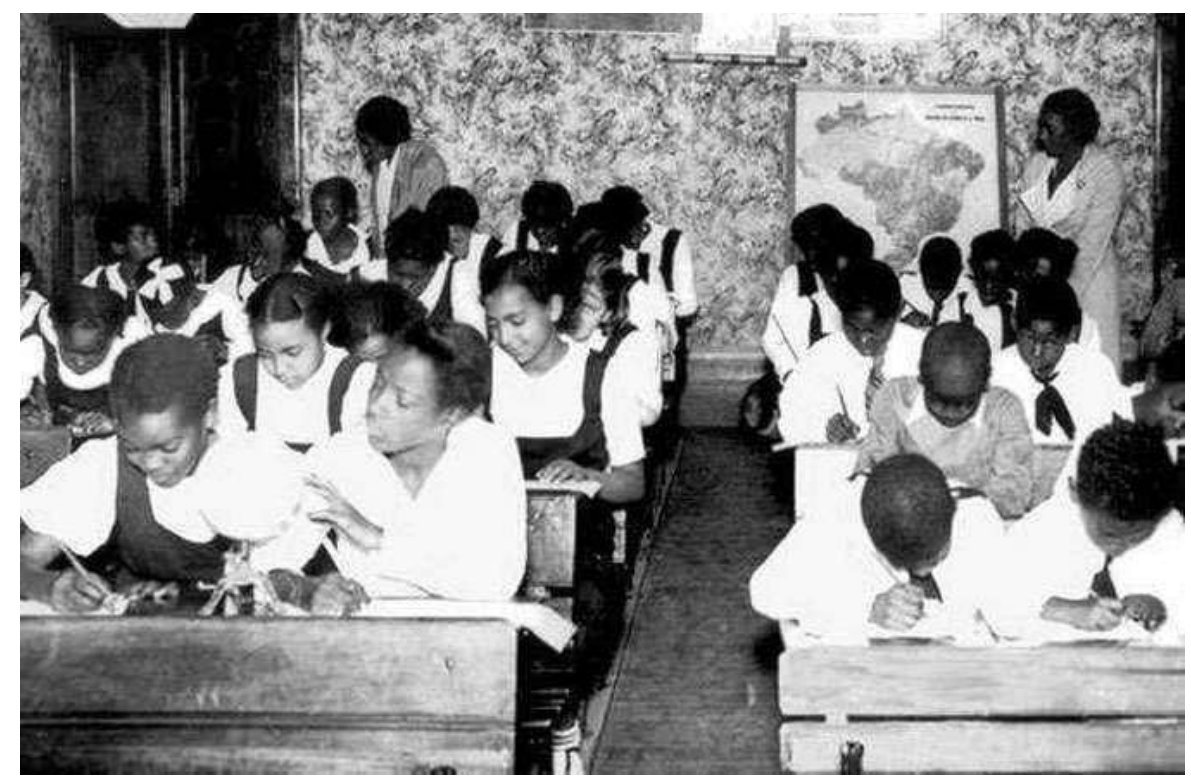

Figura 10: Escola da FNB.

Fonte: Ensinar historia Joelza

A segunda fase do movimento negro estruturada pelo sociólogo Petrônio Domingues vai de 1945 a 1964, isto porque, com a vigência do Estado Novo ( 1937-1945) irá ter inúmeras repressões por parte da ditadura "varguista" para com diversos movimentos políticos nacionais ${ }^{54}$; a própria extinção da FNB,em 1937, é conseqüência de um dos decreto do presidente Getulio Vargas que, colocava na ilegalidade qualquer tipo de organização com o cunho político. Assim, como a queda deste período, ocorre o ressurgimento do movimentos políticos e conseqüentemente aquele especifico para pensar e organizar o corpo negro no território nacional, assim, será nesta segunda fase que o raio de ação do movimento negro irá ampliar( DOMINGUES, 2007). Esta ampliação é resultado da discriminação racial que neste contexto estava posta e o auto índice de segregação econômica e cultural deixava ainda mais a margens as problemáticas de cidadanias diferencias para a população negra, porém,as

\footnotetext{
${ }^{54}$ É importante salientar que no campo da atuação política o FNB irá ressaltar a importância do negro(a) superar a condição subalterna como cabo eleitoral, incentivando candidatura negras e chegando, inclusive, a se organizar co mo partido político em 1936 (IPEAFRO), <http://ipeafro.org.br/acervodigital/documentos/antecedentes-do-ten/frente-negra-brasileira/> : Aces so em 25 set. 2019.
} 
ações do movimento negro não seriam tão aglutinada como foi na primeira fase (Domingues, 2007). Como destaque deste período temo a União dos Homens de Cor (UHC) que, com uma complexa estrutura organizacional, articulava-se a partir de uma rede entre dez estados do território nacional. Segundo o Sociólogo, o UHC atuava, em linhas gerais, promovendo debates nas imprensas locais, publicando em jornais próprios, dando suporte jurídicos e médicos, inclusive, aulas de alfabetização.

Outro importante grupo que é registrado nesta segunda fase de movimento negro é o Teatro experimental do negro (TEN), no Rio de Janeiro. Tendo como representante Abdias Nascimento $^{55}$, o TEN possuía um caráter amplo de organização político-cultural. Inicialmente tinha como proposta a formação de um grupo de teatro apenas com atores negros e negras, porém, a proposta ampliou-se em sintonia com um projeto de cidadania negra, em que, ofertava-se uma narrativa de direitos civis de qualidade para população negras. Assim, a partir da criação do instituto nacional do negro, do museu do negro e de diversos congressos, que movimentavam discussão nacionais e internacionais para luta negra, o TEM, adquiriu uma postura ativa da amplos debates que envolviam a discurso da cidadania.

Com o golpe militar em 1964, o movimento pela busca do discurso/prática da cidadania negra será novamente interrompido. Essa interrupção foi justificada pelo militares ao acusaram o movimento negro de criar um suposto problema racial no Brasil (DOMINGUES, 2007), com isso, o MN, só pode retomar ativamente a luta contra o racismo e pelo direito para a cidadania negra em 1978. Com o discurso mais critico, a terceira fase será marcada pela fundação do Movimento Negro Unificado (MNU) que, segundo Petrônio Domingues, terá grande influencia externa dos movimentos pelos direitos civis norte americanos ${ }^{56}$ e pela luta pela independência dos países africanos. Na esfera interna, o MNU será influenciado pela via socialista de alguns grupos de militantes negros que entendiam o racismo como uma ferramenta de estrutural do capitalismo, assim, concebiam a luta contra o capitalismo como uma luta antiracista ${ }^{57}$. Segundo (Ibid. 2007, p.114), no programa de ação de 1982 do MNU defendia a:

\footnotetext{
${ }^{55}$ Abdias Nascimento (1914-2011) foi um dos maiores ativista social e artista( pintor/escritor/poeta) que o Brasil já teve no que diz respeito à atuação his tórica no combate contra a desigualde racial e na divulgação da cultura africana e negra brasileira.

${ }^{56}$ A segregação formal e informal nos Estados Unidos depois da segunda Guerra Mundial, privou a liberdade da população negra Norte A merica que construiu, neste contexto, um diversas ferramentas de organizacionais de lutas para a reivindicação dos seus direitos legítimos de cidadania.

${ }^{57}$ Segundo DOMINGUES (2007), para alguns militantes negros, o capitalis mo era o sistema que alienava e se beneficiava o racismo,desta forma, derrubando o sistema capitalis ta haveria, conseqüentemente, a construção de uma sociedade mais digna para a população negra.
} 
Desmistificação da democracia racial brasileira; organização política da população negra; transformação do Movimento Negro em movimento de massas; formação de um amplo leque de alianças na luta contra o racismo e a exploração do trabalhador; organização para enfrentar a violência policial; organização nos sindicatos e partidos políticos; luta pela introdução da História da África e do Negro no Brasil nos currículos escolares ${ }^{58}$, bem como a busca pelo apoio internacional contra o racismo no país.

Será muito importante, nesta terceira fase, a forma como o movimente negro ingressa no debate sobre educação, intervindo, "a miute no terreno educacional". Como vimos, na primeira e na segunda fase, irá existir significativos projetos de escolas negras, porém, esses projetos se limitavam em propostas internas aos grupos. O MNU, será mais ousado, com propostas profunda de revisão dos conteúdos curriculares que estivessem carregados com estereótipos que envolviam o corpo-história-negra. Desta forma, irão propor capacitação de professores para desenvolvimento de conteúdos pedagógicos interétnicos para as aulas nas escolas brasileira, ou seja, já na década de 80, haveria, por parte do Movimento Negro Unificado, um ensaio do que seria aprovado apenas no século seguinte, com a aprovação da lei 10.630. Com isto, o surgimento do MNU, representou um marco histórico no que diz respeito ao protesto negro pelos direitos civis; unificou a luta entre diferentes grupos e organização que possuíam como pauta ações antirracista com o intuito de fortalecimento político do movimento negro ( DOMINGUES, 2007).

A presença ativa do movimento negro marcou um processo de narrativa a cerca das políticas nacional, que influenciou luta pela cidadania em diferente Geografias. Não diferente foi no território da USP, onde, o movimento negro esteve(está) presente, a partir de grupos/coletivos negros que possuem uma importante função de ligação entre o discurso pelo direito a cidadania negra e a ocupação do corpo negro(a) no território do ensino superior.Assim, uma das importantes ferramentas para a realização do objetivo inscrito nesta agenda de ação, é as cotas raciais, que, possuem, neste processo de organização/ocupação de direitos, um papel direto na realocação dos sentidos, de que deve estar presente no território da universidade. Assim, apesar de existências de múltiplos grupos que, carregam a significância/significado na construção deste vinculo sócio-racial universitário de luta, fizemos a decisão de escolha do Núcleo de Consciência Negra (NCN), como analise das ações que condizem aos direitos pelo ensino universitário por parte da população negra. 


\subsubsection{Um olhar sobre o NCN, outro para a cidadania.}

Escolhemos o Núcleo de Consciência negra(NCN) para uma análise crítica sobre a luta em busca da cidadania negra no território da USP Butantã. Entendemos que há( e existiram) diversos grupos e coletivos que, como já dito, tiveram(possuem) um significado no processo de re-leitura sobre a territorialidade negra ${ }^{59}$ na universidade, porém, será o $\mathrm{NCN}$, onde, perceberemos a materialização de uma convergência entre os dois grupos que dialogam neste trabalho: Servidore(a)s ( técnicos- administrativo(a)s e professore(a)s) e estudantes que se apropriaram do espaço do MN buscar a transformação territorial da USP.

O Núcleo de Consciência negra (NCN) foi fundado em 1987, a partir da iniciativa dos Servidores e estudantes que, com o objetivo de lutar contra o racismo, o preconceito e todas formas de discriminação, se articulam para criar essa etindade que sem nenhum fruto lucrativo atua dentro do território, ao mesmo que, dialoga e faz redes como diferentes grupos e movimentos negros(fora e dentro da universidade) para fortalecimento do seus projetos ações. Sua territorialização dentro da Universidade de São Paulo pode ser vista como expressão das tensão raciais vividas no cotidiano da sociedade (Siqueira,2017), furando a "bolha" ${ }^{60 "}$ universidade e trazendo-a para as problemáticas reais que existem dentro e fora do território. Desta forma, a partir de um objetivo real, o NCN, desde sua criação, busca, dentro da Universidade, ações educativas para combater a segregação de negro(as), diminuindo as desigualdades, seja a partir da critica ao reduzido numero de estudantes negros e negras no território seja na luta pela valorização da cultura negra na sociedade brasileira (Ibid.,2017).

As ações diretas sobre a luta antirracista é uma da das características mais marcantes do grupo que, a partir de atividades debate/formação, boletins informativos, marchas

\footnotetext{
${ }^{59}$ Dentro da USP exis tiram (existe) inú me ros coletivos que fazem menção as mú ltip las problemáticas que se referem ao corpo negro (a) Brasileiro. Decidimos não fazer este aprofundamento dessa diversidade político cultural de movimentos negros que se insere no território trazendo significância no que diz respeito a valorização da cultura negra e a luta no co mbate a desigualdades raciais na USP.Porém, cabe fazer u ma ressalva a dois movimentos que marcaram o processo de construção deste trabalho: O primeiro, ainda ativo é a Secretária de Negro, Negras e Combate ao Racismo(do SINTUSP-Sindicato dos Trabalhadores da USP) e o segundo, não mais ativo, é a Ocupação preta.A ocupação preta, foi u m movimento organizado por estudantes negro(a) de graduação da USP, se concentrou no ano de 2015 e tinha como objetivo trazer a importância das cotas raciais a partir de ocupações em aulas dentro do território do USP.Já a secretaria, é u m segmento do SITUSP e desenvolve encontros e passeata com objetivo de levantar o debate da desigualdade racial e do racismos institucional para o campo do funcionalis mo

${ }^{60}$ Uma das expressão para referencias a não vinculação da universidade com proble máticas centrais que então na raiz da sociedade.
} 
temáticas e o cursinho. Este último é uma consequiência da ótica padrão que resulta na ausência negra no território da USP; essa que, desde sua formação fora umas das motivações de organização do Núcleo, em 1994, originou o cursinho pré-vestibular para atender funcionários terceirizados da USP, jovens e adultos do entorno da universidade e de outros bairros da cidade de São Paulo, desta forma, para além de educar, o cursinho representa para o NCN, um projeto educacional que "proporciona a afirmação da identidade do negro, como sujeito político, dentro da sociedade"( SIQUEIRA, 2017, p.20)

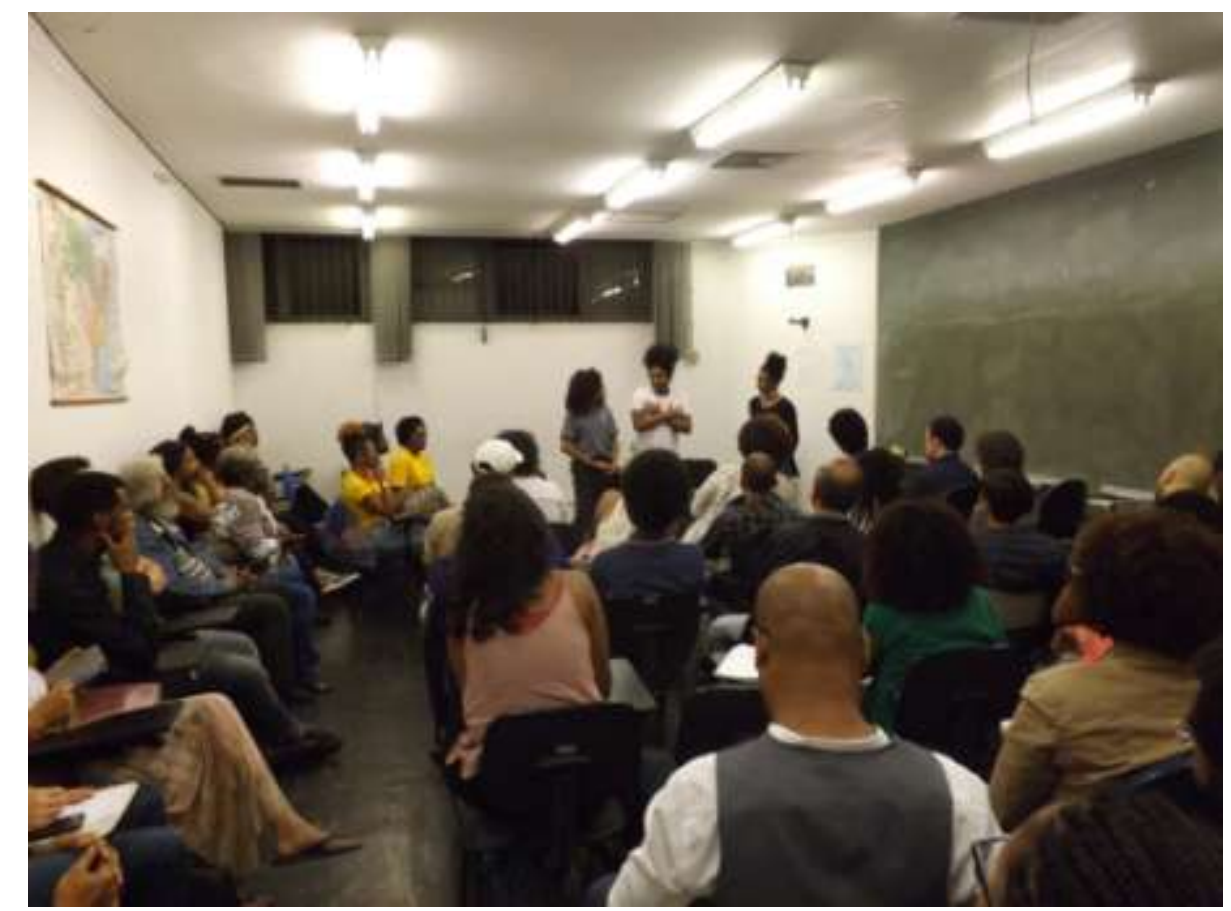

Figura 11: Reunião dos 30 anos do NCN.

Fonte: da pesquisa. 2018

Outra ação do NCN, foi ocupação do restaurante Maksould Plaza ${ }^{61}$ que marcou não somente história do grupo como resultou em um dos manifestos mais marcantes da história do movimento negro de São Paulo. Intitulado "Projeto Reparações", a ação de ocupação do restaurante visava divulgar a importância das cotas raciais no contexto das relações sócioraciais brasileiras, assim, "a ideia era que toso aqueles que fizessem parte do movimento negro participassem de um almoço em um caro restaurante, no caso de São Paulo, no Maksoud Plaza, e não pagassem a conta[..] não pagaria nada porque acreditavam que a conta já havia sido paga pelos seus ancestrais escravizados".(SIQUEIRA, 2017, p.16)

\footnotetext{
${ }^{61}$ Restaurante de lu xo localizado no bairro da Bela vista.
} 
O NCN é fundando no contexto da terceira fase do movimento negro( Domingues,2007), onde, logo no final da ditadura militar, no período de redemocratização, irá ocupar a USP para reintegrar o discurso sobre o corpo negro no território frisado pela ausência de narrativas negras.

Essa reintegração de discurso acaba trazendo para a relação entre USP e NCN, conflitos territoriais que acarretarão em uma série de dificuldades em relação ao reconhecimento e a visibilidade da Universidade para com o Núcleo (SIQUEIRA,2017). Os entraves em conseguir um espaços físico para realização das atividades tem sido uma destas problemáticas resultantes da relação que a instituição possui com o grupo e acaba caracterizando o olhar que se tem para o debate fomentado pelo NCN. A primeira sede ${ }^{62}$ foi o que chamavam de "Barracão" e que, mesmo precária, foi pelos membros revitalizada para a realização das atividades culturais, estudos e a realização de pesquisas estatísticas sobre o Negro Brasileiro(Ibid., 2017). Essas dificuldades em relação a um espaço dentro do território resultaram por outro lado, em uma importante autonomia perante a instituição o que, permitiu denunciar a discriminação racial( e o racismo institucional) dentro do território.

Neste gancho, que vincula a luta pelo acesso aos jovens negro (a)s à Universidade e o combate as desigualdades na intuição que, o NCN, irá travar a maior luta: As Cotas raciais. Essa política afirmativa irá se tornar uma ferramenta de enfrentamento, mas também, de possibilidade de transformação do território da USP, permitindo o MN universitário fazer uma rede territorial com outros grupo e instituição para consolidar aquilo que seria uma das maiores conquistas reparatória para a população negra.

\subsection{As cotas como instrumento de inclusão do território}

“A natureza do espaço" (SANTOS, 2011) das universidades públicas do Estado de São Paulo pode permitir uma discussão sobre a geografia dos movimentos sociais sob a ótica da participação na construção e no uso desses territórios.

Em se tratando de universidades públicas, pode-se perceber uma ascensão na forma como o Movimento Negro ${ }^{63}(\mathrm{MN})$ tem posto em prática a pauta da luta da população negra

\footnotetext{
${ }^{62}$ Hoje o NCN se encontra no antigo espaço dos Institutos de Estudos Brasileiros (IEB).

${ }^{63}$ Segundo Domingues (2007, p.101): “(...) pode-se caracterizar movimento social como um 'grupo mais ou menos organizado, sob uma liderança determinada ou não; possuindo programas, objetivos ou planos em comu m; baseando-se numa mes ma doutrina, princípios valorativos ou ideologia; visando um fim específico ou uma mudança social'. Mas, nesse cenário, como pode ser definido movimento negro? Movimento negro é a luta
} 
brasileira e, atrelado a isso, a discussão do direito ao espaço público. O movimento tem engajado a Geografia com uma proposta jurídica a respeito do território universitário, com base na norma associada às políticas públicas, mais especificamente às cotas raciais.

Santos (2011) pontua que a proposta atual da Geografia deve considerar a disciplina como um estudo indissociável do sistema de objetos e do sistema de ações para o entendimento de como se dá a produção e a formação do espaço. No caso do presente estudo, o que se percebe é que a compreensão separada da dinâmica dos objetos e das ações restringe e empobrece a análise da territorialidade da comunidade negra dentro do campus universitário, reduzindo a compreensão a respeito do modo como o movimento negro dialoga com as múltiplas características que envolvem a comunidade negra na proposta de transformação do espaço social, pois

Sistema de objetos e sistema de ações interagem. De um lado, os sistemas de objetos condicionam a forma como se dão as ações e, de outro, o sistema de ações leva à criação de objetos novos ou se realiza sobre objetos preexistentes. É assim que o espaço encontra a sua dinâmica e se transforma. (Ibid., p. 63)

É importante salientar que, quando estamos relacionando as ações do movimento negro com o conceito de objeto, não estamos atrelando esse grupo político a uma ideia de "coisa". Objeto aqui tem a conotação atribuída por Milton Santos (2011, p.63), ou seja, significa uma "elaboração social", ou preferencialmente, "resultado do trabalho", de maneira que as normas também podem ser consideradas um objeto (ANTAS JR., 2004, p. 82), já que "para a construção de uma ponte, por exemplo, é necessária a demanda e a produção de uma extensa normatização". No caso do grupo analisado - o movimento negro -, não estamos nos referindo a uma proposta analítica que os envolve em uma arquitetura e engenharia de estruturas fixas de concreto e que marcariam a paisagem de um grande cidade, mas à norma presente na figura das cotas raciais que se tornam, para a leitura do objeto geográfico, um importante instrumento para a produção do espaço.

As cotas raciais, como lei, são "formas sociais não-geográficas" que se tornam "um dia ou outro, formas sociais geográficas"(SANTOS, 2011, p. 75), uma vez que se relacionam

dos negros na perspectiva de resolver seus problemas na sociedade abrangente, em particular os provenientes dos preconceitos e das discriminações raciais, que os marginalizam no mercado de trabalho, no sistema educacional, político, social e cultural. Para o movimento negro, a "raça" e, por conseguinte, a identidade racial, é utilizada não só como elemento de mobilização, mas também de mediação das reivindicações políticas. Em outras palavras, para o movimento negro, a "raça" é o fator determinante de organização dos negros em torno de um projeto comum de ação". 
com um tipo de organização geográfica. Como uma política pública de ação afirmativa, as cotas acabam sendo assumidas como instrumento analítico de questões que tangem ações, metas e objetivos para o enfrentamento das mazelas que permeiam a formação histórica da população brasileira:

\begin{abstract}
Num país onde os preconceitos e a discriminação racial não foram zerados, ou seja, onde os alunos brancos pobres e negros pobres ainda não são iguais, pois uns são discriminados uma vez pela condição socioeconômica e outro são discriminados duas vezes, pela condição racial e pela condição socioeconômica, as políticas ditas universais[...] não atraíram mudanças substanciais esperadas para a população negra[...]É nesse contexto que colocamos a importância da implementação de políticas de Ação Afirmativa, entre as quais a experiência das cotas que, pela experiência de outros países, se afirmou como instrumento veloz de transformação, sobretudo no domínio da mobilidade socioeconômica, considerada como um dos aspectos não menos importantes da desigualdade racial. (MUNANGA, 2006, p.49)
\end{abstract}

A descrição do professor Kabengele Munanga sobre a importância das cotas raciais também levanta questões sobre a correlação entre o espaço e o contexto histórico, considerando que, em um país de raízes escravocratas, não há como discutir questões sociais sem vinculá-las ao debate sobre o negro (MOURA, 2014). As políticas de ações afirmativas seguem esse vínculo contextual, mas com um momento específico de aplicação, pois "toda criação de objetos reponde à condição social e técnica presente num dado momento histórico" (SANTOS, 2011, p. 68).

No caso do Brasil, as cotas começaram a ser pensadas em 2001, a partir da Conferência Mundial Contra o Racismo, a Discriminação Racial, a Xenofobia e Formas Correlatas de Intolerância em Durban, na África do Sul, que

(...) foi precedida por uma série de eventos e relatórios que gradativamente adquiriram visibilidade na mídia envolvendo, sobretudo, diversas agências do Estado brasileiro, políticos, acadêmicos, ONGs, organizações do movimento negro e fundações filantrópicas estadunidenses na denúncia do racismo e das desigualdades raciais no Brasil. Nesse último caso, basta lembrar o exemplo da Fundação Ford que, a partir dos anos 1990, redefine sua orientação científica-política ao privilegiar uma agenda de intervenção social no país. (MAIO; SANTOS, 2005, p.1)

Com a conferência mundial e a pressão vinda do movimento negro, o governo brasileiro definiu um programa de política de cotas no âmbito de alguns ministérios. Nesse contexto, a Universidade de Brasília (UnB) se tornou em 2004 a primeira universidade pública a adotar a norma do sistema de cotas para o ingresso dos alunos como uma forma de 
responder ao racismo (Ibid., p. 1). Nesse sentido, as cotas, depois da reivindicação do movimento negro e da Conferência de Durban, se transformam em uma ação de fato depois de serem fundamentadas técnica e institucionalmente nesse período.

Esse sistema de objetos, que converge para a norma das políticas públicas e é indissociável de um conjunto de sistema de ações, carrega uma especificidade que apenas as cotas raciais possuem: a influência de um passado escravocrata no corpo negro. Assim, o valor social que a lei de cotas historicamente fornece para o debate do movimento negro é repleto de diálogos entre diferentes lógicas temporais, importantes não só para a compreensão cronológica das pautas dos movimentos, mas também para o paralelo com o sistema de objetos e ações:

Esses objetos e essas ações são reunidos numa lógica que é, ao mesmo tempo a lógica da história passada(sua datação, sua realidade material, sua causalidade original)e a lógica da atualidade (seu funcionamento e sua significação presente).Trata-se de reconhecer o valor social dos objetos mediante o enfoque geográfico. A significação geográfica e o valor geográfico dos objetos vêm do papel que, pelo fato de estarem em contiguidade, formam uma extensão contínua e, sistemicamente interligados, eles desempenham no processo social. (SANTOS, 2011, p. 75)

Apesar da importante discussão que o debate sobre cotas provoca na luta contra o fosso social que existe entre a população negra e a branca (OSÓRIO, 2006), a abertura da discussão e o esforço para se discutir a democratização da universidade pública ainda se concentram no movimento negro como ator da mudança. Santos (2011) ressalta, inclusive, a importância de distinguir os atores que são realmente a mudança e "os outros", atores que decidem o que será difundido, “aquele capaz de escolher a ação” (Ibid., p. 75).

O movimento negro universitário tem levantado a bandeira da mudança no sistema de ingresso de estudantes negros nas universidades, alegando que, em um sistema racializado (SANTOS, 2012), os jovens negros com interesse em ingressar no ensino superior por meio do vestibular estão em desvantagem. Essa organização escreve, assim, não apenas uma agenda de luta, mas também propõe uma regulamentação do espaço das universidades, já que as cotas, como uma lei ${ }^{64}$, permitem uma territorialidade em diversos espaços das instituições e a presença de sujeitos que historicamente foram marginalizados. Assim, "a regulação social e territorial, quer nos parecer, é efetivamente exercida pela instância que detém poder de fato e não apenas um poder declarado" (ANTAS JR., 2004, p.84).

\footnotetext{
${ }^{64}$ Milton Santos (2011) se refere a Emile Durkheim (1895) para falar sobre a lei. Segundo ele, as leis seriam meios de ação cristalizada que vêm do passado e se impõem no presente.
} 
Esse poder de regulamentação de um espaço geográfico, presente em uma organização social, evidencia que o Estado não é o único a introduzir uma jurisprudência dentro de um território determinado. O MN ilustra, a partir da luta pela implementação de políticas afirmativas, que o Estado ocidental tem perdido o monopólio na produção de normas jurídicas (ANTAS JR., 2003), reivindicando, dessa maneira, o direito à revisão dos sujeitos que ocupam a universidade. Essa ideia, que o professor Ricardo Antas pontua como "pluralismo jurídico", confere não somente ao Estado a ação de regulamentação social, econômica e política, mas também a "vários sistemas e subsistemas de ações, em co-presença nos lugares" (Ibid., p. 83).

Essa dimensão, que faz com que as políticas ligadas a direitos não sejam centralizadas apenas na imagem do Estado - representado nesta pesquisa pela instituição universitária-, possibilita aos movimentos sociais a criação de uma expectativa de mudança nos diversos lugares em que se mobilizam. No caso do movimento negro universitário, o espaço de mobilização são as próprias universidades.

Nas universidades públicas estaduais de São Paulo, onde as cotas raciais foram efetivamente implantadas apenas recentemente, durante a execução desta pesquisa, percebese que o movimento negro tem sido o sujeito de pressão frente às decisões institucionalizadas das reitorias. Compreendendo a Universidade de São Paulo como a principal universidade brasileira e sua estrutura simbólica diante das decisões, observa-se que essa postura contraria a posição nacional das universidades federais, o que transforma seu território em um palco de discursos constantes de luta e de participação direta na implementação do pluralismo jurídico.

\subsection{O movime nto negro da USP e as cotas}

A bússola que guia as diversas decisões do movimento negro universitário da USP é o corpo negro. Sua especificidade histórica, assim como a forma de ocupar os espaços geográficos, são norteadas pela estrutura do corpo. Este, conceituado por Harvey (2004, p.137), não é "uma entidade fechada e lacrada, mas uma 'coisa relacional' que é criada, delimitada, sustentada e, em uma última análise, dissolvida num fluxo espaço-temporal de múltiplos processos", e conduzo nosso modo de olhar para a importância das cotas raciais dentro da universidade.

A luta pela consolidação das cotas como uma norma dentro da USP esteve na agenda do Núcleo de Consciência Negra da USP (NCN), organização negra fundada em 1987, a 
partir da solidariedade de funcionários, estudantes e professores da própria instituição, que se organizaram pela reciprocidade e convergência que envolve corpo negro. De forma autônoma, o Núcleo desenvolveu diversos projetos educacionais e sociais dentro do espaço universitário com o objetivo de emancipar um corpo colonizado ${ }^{65}$, formar jovens negros e brancos pobres e estruturar os caminhos para a conquistas das cotas na USP. Segundo o NCN, quando se discutia a implementação de políticas de ações afirmativas no interior da universidade, geralmente aparecia um ponto de vista que evidenciava a desvalorização,por parte da instituição, da legalidade das cotas, mesmo implementadas há anos ${ }^{66}$ em algumas instituições federais, como pontuou Maria José Menezes, membro da NCN, antes da implementação da política:

As universidades paulistas são um dos últimos resíduos de resistência da aplicação de políticas e ações afirmativas para a população negra e indígena no país. Cotas raciais na USP não são uma concessão dessa instituição nem um favor. Estamos cobrando das três instituições de ensino superior público de São Paulo que sejam aplicadas as políticas de reserva de vagas. Não queremos bônus ${ }^{67}$, mas reserva de vagas para a população negra e indígena por todo o histórico de luta e de contribuição que essas populações tiveram e têm na formação e na manutenção do país.

Quanto a essa questão, o professor Kabengele Munanga (2003, p. 48) complementa que:

O que se busca pela política de cotas para negro e indígena não é para terem direito a migalhas, mas sim para estarem no topo em todos os setores de responsabilidade e de comando na vida nacional, onde esses dois segmentos não são devidamente representados, como manda a verdadeira democracia.

A compreensão das especificidades que tangem a população negra, atribuindo a sua condição uma multiplicidade de outros aspectos que estão inscritos apenas em seu corpo por causa de diferentes virtudes (HARVEY, 2004), tem sido o maior embate para o movimento

\footnotetext{
${ }^{65}$ No caso do negro brasileiro, veremos que há inúmeras especificidades, criadas por práticas ideológicas raciais, que não só funcionarão como instrumentos de dominação colonial (QUIJANO, 2005).

${ }^{66}$ Disponível em: <http://www.planalto.gov.br/ccivil_03/_ato2011-2014/2012/Lei/L12711.htm>. Acesso: 16 dez. 2017.

${ }^{67}$ O Sistema de Inclusão Social (INCLUSP) é u m programa social da Universidade de São Paulo, desenvolvido para incentivar a participação de estudantes de escolas públicas no vestibular da FUVEST a partir de uma política de bonificação que serve para potencializar as chances dos ingressos através de um acréscimo (bônus) na nota do vestibular e para propiciar a permanência dos aprovados que sofram desvantagens socioeconômicas. Porém, essa política somente atende alunos que passaram na primeira fase, em que o acréscimo vale unicamente para a soma da nota da primeira fase e da segunda.
} 
negro universitário, que tem se articulado em rede para fortalecer a luta ${ }^{68}$ pela normatização das cotas nas universidades paulistas e das políticas de permanência dentro dos territórios universitário. Até mesmo dentro da Universidade de São Paulo proliferam, como sintoma desse ambiente de articulação social, inúmeros coletivos negros que têm demonstrado que a articulação do corpo é uma estratégia de luta, como a Ocupação Preta.

Boaventura de Sousa Santos (1991), em seu trabalho sobre a cartografia simbólica das representações sociais, faz uma analogia das leis com as representações cartográficas. Estas, como as leis, possuem o papel de representação da realidade, de "contextura espacial" para a “compreensão da realidade" (Ibid., p.140). O que vemos, a partir da leitura de Santos (1991), é que as instituições têm uma projeção e uma escala sobre o direito à lei de cotas raciais que é diferente das projeções e escalas dos movimentos sociais.

A projeção é um importante instrumento para, a partir da distorção, ter uma percepção da realidadeque pode causar diferentes interpretações sobre as cotas, já que cada tipo de projeção representa sempre um compromisso: “A decisão sobre o tipo e o grau de distorção a privilegiar é condicionada por fatores técnicos, mas não deixa de ser baseada na ideologia do cartógrafo e no uso específico a que o mapa se destina" (Ibid., p. 71). Em uma sociedade marcada pelo racismo, a clivagem racial é uma variável nas decisões sobre como é projetada a construção ou não da lei de cotas raciais dentro da USP, o que ocorre também pelo fato de a projeção ser um instrumento cartográfico não neutro, influenciado por elementos sociais externos.

Outra característica importante para entender essa leitura diferenciada sobre as cotas raciais está na escala. Esse instrumento permite compreender porque, mesmo em uma escala nacional e apesar da aceitação e incorporação institucional das cotas, a USP ainda insiste em ter uma realidade jurídica diferente de outras universidades. O fato é que, no Estado moderno, o tamanho da escala distingue o direito e a legalidade. Em um mesmo objeto jurídico, no caso das cotas, se impõem escalas e tamanhos de significados diferentes para cada lugar. Assim:

As diferentes ordens jurídicas operam, assim, em escalas diferentes e, com isso, traduzem objetos empíricos eventualmente iguais em objetos jurídicos distintos. Acontece, porém, que na prática social as diferentes escalas

\footnotetext{
${ }^{68}$ A Frente Pró-Cotas Raciais do Estado de São Paulo foi criada para aglutinar grupos e coletivos negros das universidades estaduais de São Paulo em prol da luta pela institucionalização das cotas raciais. Hoje a Frente tem se art iculado para imple mentação das cotas na pós -graduação.
} 
jurídicas não existem isoladas e, pelo contrário, interagem de diferentes maneiras. (Ibid., p. 68)

Também é fundamental salientar que a existência de diferentes escalas jurídicas em um mesmo espaço contraria o pressuposto de que o Direito no Estado moderno trabalha apenas em uma única escala (SANTOS, 1991), retomando a ideia de pluralismo jurídico apresentada anteriormente. Dessa forma, mesmo tendo uma escala de entendimento e de legitimidade diferente da escala do movimento negro, a instituição, em um espaço onde convivem dois sistemas de direitos que são reivindicados e legitimados constantemente, pode não ser a única a participar dos processos de decisão, pois é nítida, por exemplo, a pressão do movimento negro universitário, com inúmeras táticas ${ }^{69}$ voltadas à consolidação das leis de cotas raciais dentro da USP.

Mike Davis (2009,p.177), em seu livro sobre a Cidade de Quartzo, abordou a racialização do espaço de Los Angeles a partir dos zoneamentos de distritos "exclusivamente para residência de famílias de alto nível” - leia-se brancas. De modo análogo, embora envolva espaços e tempos diferentes, observamos a mesma prática sendo criticada pelo movimento negro da USP, que faz questionamentos a respeito de quem ocupa o território da universidade pública. Como em Los Angeles, a USP também se caracterizou, antes da aplicação da cotas, pelo "zoneamento exclusivista e a regulamentação severa dos loteamentos" (Ibid., p. 177), não da perspectiva de um bairro, mas do ingresso que, baseado em um vestibular que não distinguia as singularidades sociais e raciais, causava, para a realidade espacial do território, um zoneamento exclusivo entre cursos onde predominavam estudantes negros e cursos onde sua presença era quase nula.

A homogeneidade racial e social, articulada por uma legislação discriminatória (DAVIS, 2009), criou em Los Angeles restrições espaciais e desenvolveu um muro branco em torno da comunidade negra. Por isso, o que entendemos aqui é que as cotas raciais, como um objeto jurídico,se vinculam à ação de desconstrução de uma leitura homogênea de universidade para o desenvolvimento de uma imagem de universidade plural, que efetivamente represente a sociedade brasileira.

\footnotetext{
${ }^{69}$ As táticas variam desde atos, manifestações e passeatas pelas ruas de São Paulo até palestras com a temática e ocupações em salas de aula para sensibilizar a co munidade acadêmica.
} 


\section{CONSIDERAÇÕES FINAIS}

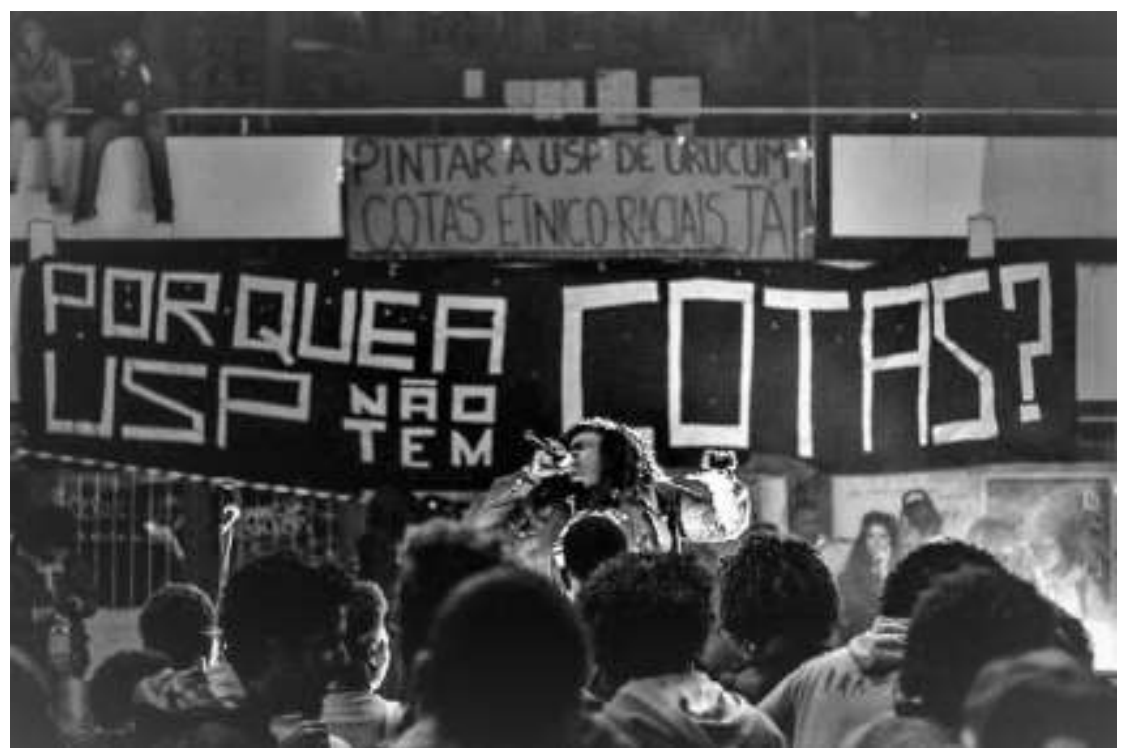

Figura 10 - Protesto a favor da implantação de cotas raciais na USP. Fonte: Alma Preta ${ }^{70}$

No dia 4 de julho de 2017, numa terça-feira, foram aprovadas as cotas no vestibular ${ }^{71}$ da Universidade de São Paulo. Foram necessários 75 votos e 300 assinaturas de docentes da universidade em uma reunião histórica do Conselho Universitário(CO) para ser quebrado o legado de retrocesso ${ }^{72}$ em relação à aplicação de reserva de vagas sociais e étnico-raciais no processo seletivo da USP.

Porém, ao contrário do que se possa imaginar, toda essa reação em favor das cotas não significou uma flexibilização da ação dos membros do Conselho $^{73}$, pois foi uma consequência da luta que o movimento negro universitário engendrava há anos em sua agenda. As cotas representam, assim, a materialização de um legado histórico construído pelo

\footnotetext{
${ }^{70}$ Dis ponível em: <http://www.almapreta.co m/editoria is/realidade/comite-para-fiscalizar-cotas-raciais-e-criadona-usp>. Acesso em 25 set. 2019.

71 É importante pontuar que, antes mesmo da implementação das cotas, a USP havia realizado algumas tentativas de ações afirmativas para o ingresso de estudantes nos diferentes cursos da universidade, como INCLUSP (Inclusão Social da USP), um sistema de bonificação em seu processo de seletivo.Essa medida afirmativa possibilitava que os estudantes oriundos de escola pública tives sem u m acréscimo porcentual na nota. Em 2012, a universidade adotaria também o Programa de Avaliação Serial da USP(PASUSP), voltado para alunos de escolas públicas ainda no ensino médio, que teriam também um acréscimo na nota nas duas fases do vestibular. Apenas em2015, com a adesão experimental ao SISU, que será pensada uma reserva racial e social das vagas, mas sendo a adoção opcional para cada faculdade e instituto.

${ }^{72}$ A USP foi a última a universidade a adotar as cotas no Estado de São Paulo.

${ }^{73} \mathrm{Ver}$ mais em: <https://www.cartacapital.co m.br/sociedade/cotas-na-usp-o-desafio-agora-e-garantir-apermanencia-dos-alunos/>. Acesso em 15 set. 2019.
} 
movimento negro ${ }^{74}$, que sempre viu na educação uma importante política para a redução das desigualdades socioeconômicas que envolvem a população negra.Sendo assim, muito antes da aprovação dessa política pública em uma reunião do $\mathrm{CO}$ o movimento negro universitário já se articulava, inclusive com propostas maduras ${ }^{75}$, para a implementação das cotas nos campi da USP.

Essa conquista, embora tardia, se tornou um marco para pensarmos as ações desenhadas pelo movimento negro, principalmente no campus da USP-Butantã. São ações que se apropriam das contradições existentes no território para fazer desse espaço um fator ativo(SANTOS,2012), onde os dados problemáticos em relação à presença negra serão fundamentalmente convertidos em formas de luta para fomentar encontros,passeatas e discussões sobre as disparidades do corpo negro no território universitário.

No caso do presente trabalho, revelamos dados por meio de gráficos e mapas que permitiram localizar no território da USP as distintas e desiguais densidades negras no espaço. Essa espacialização das diferenças nos possibilitou levantar um debate em que pessoas com as mesmas virtualidades, a mesma formação e até mesmo o mesmo salário, possuíam valores diferentes segundo o lugar que ocupavam (Santos, 2000), o que reforça a importância da luta pela democratização desse território.

Entretanto, além dos dados quantitativos, vimos que outras narrativas são necessárias para analisar esse envolvimento entre território e corpo negro. São narrativas que, como explica Correia (2017), acompanham o território e são um importante conteúdo para identificar o grupo observado e explicar, na ótica da população negra, o que faz esse território ser o que é.

Mesmo sendo significativas para um panorama sobre a universidade, essas narrativas negras muitas vezes são invisibilizadas e apagadas nos livros oficiais da instituição, reforçando a lógica de branqueamento que manipula as narrativas de um grupo sobre outro em favor de uma disputa de versões que incide sobre a imagem que se tem do

\footnotetext{
${ }^{74}$ Maria Conceição de Jesus(2015) trazem seu mestrado uma importante análise sobre o legado da militância negra para a democratização das relações étnico-raciais.Abordando pós-64, a pesquisadora, a partir de fontes documentais do período militar brasileiro, comprova ações e contribuições do movimento negro para a democratização da educação.

75 O movimento negro já havia apresentado para o Conselho de Graduação(COG) uma proposta de implementação de cotas que se baseava na Lei de Cotas de 2012, quando foi pensada uma reserva de vagas de $50 \%$ para alunos de escolas públicas, com 37,5\% para candidatos autodeclarados pretos, pardos ou indígenas(PPI), sendo esse último valor o equivalente à proporção de negros no estado de São Paulo.Porém, o COG negou a proposta enviada e considerou apenas uma proposta baseada em cotas sociais, desconsiderando o perfil étnico-racial dos candidatos.
} 
território(CORREIA, 2017). Apesar disso, acreditamos, como Milton Santos(2012,p.82), que o "território em que vivemos é mais que um simples conjunto de objetos, mediante os quais trabalhamos, circulamos, moramos", pois é “também um dado simbólico". Essa dimensão esteve presente nas entrevistas coletadas e cruzadas que tonalizaram tanto servidores como estudantes negros(as) como sujeitos que se percebem no espaço. Esse ato de se perceber:

Ultrapassa os sentidos e ganha a razão. É assim que se opera a metamorfose do sensorial, mudado em conhecimento. Este se alimenta da relação entre sujeito e objeto, relação em que este, permanecendo o que é, e interagindo com o suje ito, contribuem para que, nessa interação, o suje ito evolua. É essa mesma evolução que permite revisitar o objeto, vendo-o de forma nova, despojando-o de símbolos que escondem a sua realidade profunda. É a vitória da individualidade, da individualidade forte que ultrapassa a barreira da práxis repetitiva e se instala uma práxis libertadora. (SANTOS, 2012, p. 71)

Essa "individualidade forte", transbordou neste trabalho, aglutinando todo um arcabouço das relações étnico-raciais presente entre servidores e estudantes, nos fazendo pensar sobre a potência da existência desses sujeitos no território da USP e alimentando não somente um debate sobre sua ausência em determinados espaços, mas também a presença da universidade nas diferentes trajetórias negras reveladas.

As cotas ganharam sentido e razão a partir de tudo isso, e entendemos que é necessário que se opere essa política pública de reserva de vagas também para os(as)trabalhadores(as) negros(as). Ainda há muito para se territorializar nessa luta, mas é fato que essa territorialidade do corpo negro na USP não envolve ver a universidade apenas como um simples espaço para estudar ou trabalhar, pois esse território forma também uma comunhão que abarca toda uma (geo)grafia negra da população brasileira. 


\section{REFERÊNCIAS BIBLIOGRÁFICAS}

ACSELRAD, H. (org.). Cartografias sociais e território. Rio de Janeiro: Instituto de Pesquisa e Planejamento Urbano e Regional, 2008.

ADICHIE, C. N. O perigo de uma história única. CONFERÊNCIA ANUAL - TED GLOBAL, Oxford, 2009. Disponível em: <https://www.geledes.org.br/chimamanda-adichieo-perigo-de-uma-unica-historia/>. Acesso em 25 set. 2019.

ANTAS JR., R. M. Elementos para uma discussão epistemológica sobre a regulação do território.GEOUSP, São Paulo, v. 16, 2004, pp.81-86.

A norma e a técnica como elementos constitutivos do espaço geográfico: considerações sobre o ressurgimento do pluralismo jurídico. In: Território brasileiro: uso e abuso. São Paulo: Edições Territorial, 2003.

AZEVEDO, E.Raça: conceito e preconceito. São Paulo: Ática, 1987.

BANDEIRA, M. L. Território negro em espaço branco: estudo antropológico de Vila Be. São Paulo: Brasiliense, 1988.

ANTONGIOVANNI, L. L. Reflexões acerca dos usos dos territórios. IN: PERTILE, N. (Org.). Estado, Território e a Dinâmica das Fronteiras: Reflexões e Novos Desafios. Salvador: JM Gráfica e Editora LTDA, 2013.

BALDIN, N.; MUNHOZ, E. M. Snowball(bola de neve): Uma técnica metodológica para pesquisa em educação ambiental comunitária. X CONGRESSO NACIONAL DE EDUCAÇÃ̃ - EDUCERE, PUC-PR... Anais. Curitiba, 2011.

BRAGA, T. J. K. A territorialidade do servidor negro da UFV.Monografia (Trabalho de Conclusão de Curso em Geografia) - Universidade Federal de Viçosa, Viçosa, 2014.

CAMPOS, A. Do quilombo à favela: a produção do "espaço criminalizado" no Rio de Janeiro. Rio de Janeiro: Bertrand Brasil, 2005.

CAMPOS, P. F. S. História Social da Enfermagem Brasileira: Afro descendentes e formação profissional pós-30.Revista Brasileira de Enfermagem, São Paulo, v. 3, n. 6, pp.167-177, 2012.

CARDOSO, M. A. O movimento negro em Belo Horizonte, 1978-1998. Belo Horizonte:Mazza Edições,2002.

CARVALHO, J. D.Cadernos Negros: tramas entre políticas públicas, juventude, relações étnicos-raciais e formação em psicologia.Tese (Doutorado em Psicologia) - Instituto de Psicologia, Universidade Federal do Rio Grande do Sul, Porto Alegre, 2018. 
CIRQUEIRA, D. M. Entre o corpo e a teoria: questão étnico-racial na obra e na trajetória socioespacial de Milton Santos. Dissertação (Mestrado em Geografia) - Universidade Federal de Goiás, Goiânia, 2010.

Racismo e experiência do lugar em estudantes negras e negros. Geografia, Ensino \& Pesquisa, v. 21, n. 2, pp. 72-87, 2017.

COELHO, W. N.; COELHO, M. C.Raça, cor e diferença:a escola e a diversidade. $2^{\text {a }}$ ed. Belo Horizonte: Mazza, 2010.

CONCEIÇÃO, M. V. P. Rugosidade étnica e a espacialidade do preconceito racial. Dissertação (Mestrado em Geografia) - Universidade Estadual Paulista "Júlio de Mesquita Filho", Presidente Prudente, São Paulo, 2004.

DÁ VILA, J. Diploma de brancura: política social e racial no Brasil (1917-1945). Trad. Claudia Sant'Ana Martins. São Paulo: Editora UNESP, 2006.

DAVIS, M.Cidade de quartzo: escavando o futuro em Los Angeles. São Paulo: Boitempo, 2009.

DOMINGUES, P. Movimento negro brasileiro: alguns apontamentos históricos. Tempo, Rio de Janeiro, v. 12, n.23, pp.100-122, 2007.

EVARISTO, C.Literatura negra: uma poética de nossa afro-brasilidade. Scripta, v.13, n.25, pp. 17-31, 2009.

Becos da Memória. Rio de Janeiro: Pallas, 2007.

FANON, F. Pele negra, máscaras brancas. Salvador: EDUFBA, 2008.

FERNANDES, B. M. Movimentos Socioterritoriais e Movimentos Socioespaciais: Contribuição teórica para uma leitura geográfica dos movimentos sociais.Nera, Presidente Prudente, v. 8,n.6, pp.24-34, 2005.

FERNANDES, F. A integração do negro na sociedade de classes. $5^{\mathrm{a}}$ ed. São Paulo: Globo, 2008. O negro no mundo dos brancos. São Paulo: Difel,1972.

FREYRE, G.Casa-Grande \& Senzala. 50ª ed. Rio de Janeiro: Global Editora, 2005.

GERHARDT, T. E.; SILVEIRA, D. T. Métodos de pesquisa.Porto Alegre: Editora da UFRGS, 2009.

GOMES, N. L.; MARTINS;A. A.Acesso e permanência de jovens negros na universidade. $2^{\mathrm{a}}$ ed.Belo Horizonte: Autêntica,2006. 
GOMES, A. M. S. Rota e diálogo de saberes da etnobotânica transatlântica negroafricano:terreiros, quilombos, quintais da Grande BH. Tese(Doutorado em Geociências)Universidade Federal de Minas Gerais, Belo Horizonte, 2010.

GONÇALVES, C. W. P. Os (des)caminhos do meio ambiente. São Paulo: Contexto, 2006.

GONZAGA, Y. M. Trabalhadores e trabalhadoras técnicos-administrativo em educação na UFMG: relações raciais e a invisibilidade ativamente produzida. Dissertação (Mestrado em Educação) - Universidade Federal de Minas Gerais, Belo Horizonte, 2001.

GONZALES, L. Cultura, etnicidade e trabalho: efeitos lingüísticos e políticos da exploração da mulher. Annual Meeting of the Latin American Studies Association, Pittsburgh, 5-7 de abril, 1979. (mimeo).

O papel da mulher negra na sociedade brasileira. In: LUZ, M. T. Lugar da Mulher. Rio de Janeiro: Graal, 1982.

GUSMÃO, N. M. M. Questão racial e docência: olhares e trajetos. In: PRAXEDES, V. L. et. al. (org.). Memória e percurso de professores negros e negras da UFMG. Belo Horizonte: Autêntica, 2009.

HAESBAERT,R.Des-territorialização e identidade: a rede gaúcha no Nordeste.Niterói, RJ:EDUFF, 1997.

.O mito da desterritorialização:do fim dos territórios à multiterritorialidade. $4^{\mathrm{a}}$ ed. Rio de Janeiro: Bertrand Brasil, 2009.

23, pp. 35-52, 2004.

.Precarização reclusão e "exclusão" territorial.Terra Livre,Goiânia,v.2, n.

.Territórios alternativos. São Paulo: Contexto; Niterói, RJ: EDUFF,2002.

HASENBALG, C. A.; MUNANGA, K.; SCHWARCZ, L. M. (org.).Racismo: perspectiva para um estado contextualizado da sociedade. Niterói, RJ: EDUFF,1998.

HARVEY, D. Espaços da esperança. São Paulo: Edições Loyola, 2004.

JESUS, M. C. O legado da militância negra pós-64 para a democratização das relações étnico-raciais. Dissertação (Mestrado em Educação) - Universidade Federal Rural do Rio de Janeiro, Rio de Janeiro, 2015.

KILOMBA, Grada. The Mask. In: Plantation Memories: Episodes of Everyday Racism. Münster: Unrast Verlag, 2010.

LIMA, D. C. Luiza Mahin: história, mito, ficção?Repensando uma figura enigmática.África e Africanidades, v. 4, n.13, 2011.

MACHADO, C. E. D. População negra e escolarização na cidade de São Paulo nas décadas de 1920 e 1930. Dissertação (Mestrado em História) - Faculdade de Filosofia, Letras e Ciências Humanas, São Paulo, 2009. 
MAIO, M.C.; SANTOS, R. V. Política de Cotas raciais, os "olhos da sociedade" e os usos da antropologia: o caso do vestibular da Universidade de Brasília(UnB).Horiz. antropol., Porto Alegre, v.11, n. 23, pp.181-214, 2005.

MEDEIROS, R. M. V. Território, espaço de identidade.In:S AQUET,M; SPOSITO,E. S(org.). Território e territorialidade: teorias, processos e conflitos. $2^{\mathrm{a}}$ ed. Rio de Janeiro: Consequência Editora,2015.

MARCELINO, J. S.Geografia, Movimento Negro e Relações Étnico-Raciais: um diálogo necessário.Tese (Doutorado em Geografia) - Faculdade de Filosofia, Letras e Ciências Humanas, Universidade de São Paulo,São Paulo, 2018.

MINAYO, C. S. O desafio da pesquisa social. In:Pesquisa Social: teoria, método e criatividade. $28^{\text {a }}$ ed. Petrópolis, RJ: Vozes,2009.

MIRANDA, S. A.Diversidade e ações afirmativas: combatendo as desigualdades sociais. Belo Horizonte: Autêntica; Ouro Preto, MG: Universidade Federal de Ouro Preto, 2010.

MORAES, A. C. R.Território e história no Brasil. São Paulo: Hucitec, 2002.

MORAES, A. L.Memórias da população negra da cidade de São Paulo: Igreja Nossa Senhora do Rosário dos Homens Pretos (1725- 1904). Monografia (Trabalho de Graduação Integrado em Geografia) - Faculdade de Filosofia, Letras e Ciências Humanas, Universidade de São Paulo, São Paulo, 2017.

MOTOYAMA, S. USP 70 Anos: Imagens de uma História Vivida. São Paulo: EDUSP, 2006.

MOURA, C. Rebeliões da senzala: quilombos, insurreições, guerrilhas. $5^{\text {a }}$ ed.São Paulo: Anita Garibaldi, 2014.

MUNANGA, K.; GOMES, N. L.O negro no Brasil de hoje. São Paulo: Ação Educativa, 2006

MUNANGA, K. Políticas de ação afirmativa em benefício da população negra:um ponto de vista em defesa de cotas. In: GOMES, N. L. (org.). Afirmando direitos: acesso e permanência de jovens negros na universidade. $2^{\text {a }}$ ed. Belo Horizonte: Autêntica, 2006.

Sociedade, n. 29, pp. 46-52, 2003.

Ação Afirmativa em benefício da população negra. Universidade $e$ Para entender o negro no Brasil de hoje: história, realidades, problemas e caminhos. São Paulo: Ação Educativa, 2004.

.Rediscutindo a mestiçagem no Brasil: identidade nacional versus identidade negra.Petrópolis, RJ: Vozes, 1999.

Uma abordagem conceitual das noções de raça, racismo, identidade e etnia. In: BRANDÃO, A. A.Cadernos PENESB, Niterói, n.5, pp. 15-34, 2003. 
NASCIMENTO, A. O genocídio do negro brasileiro: processo de um racismo mascarado. São Paulo: Perspectiva, 2016.

OSÓRIO, R. G. Desigualdades raciais e de gênero no serviço público civil. Brasília: Secretaria Internacional do Trabalho, 2006.

PACHECO, A. C. L. Mulher negra: afetividade e solidão. Salvador: Edufba, 2013. . O sistema classificatório de "cor ou raça” do IBGE. Brasília: IPEA,2003.

QUIJANO, A. Colonialidade do poder, eurocentrismo e América Latina.In: LANDER, E. (org.). A colonialidade do saber: eurocentrismo e ciênciassociais. Perspectivas latinoamericanas. Buenos Aires: CLACSO, 2005.

O que é essa tal de raça? In:SANTOS,R. E. (org.).Diversidade,espaço e relações étnico-raciais: o Negro na geografia do Brasil. Belo Horizonte:Autêntica, 2007.

QUEIROZ, D. M.Universidade e desigualdade: brancos e negros no ensino superior. Brasília: Liber Livro, 2004.

RAFFESTIN, C.Por uma geografia do poder. Trad. de Maria Cecilia Franca. São Paulo: Ática, 1993.

RATTS, A. As Amefricanas: Mulheres Negras e feminismo na trajetória de Lélia Gonzales. In: FAZENDO GÊNERO 9: DIÁSPORA, DIVERSIDADE, DESLOCAMENTOS. Universidade Federal de Santa Catarina... Anais.Santa Catarina,2010.

Os lugares da gente negra: temas geográficos no pensamento de Beatriz Nascimento e Lélia Gonzales.In: SANTOS, R. E. (org.). Questões urbanas e racismo. Petrópolis, RJ: ABPN,2012.

.Fronteiras invisíveis: territórios negros e indígenas no Ceará. Dissertação (Mestrado em Geografia) -Faculdade de Filosofia, Letras e Ciências Humanas, Universidade de São Paulo, São Paulo, 1996.

ROCHA, M. M. Quando a favela é extensão da universidade: o Programa Avizinhar em meio às relações entre a USP e a São Remo. Dissertação (Mestrado em Educação) Faculdade de Educação, Universidade de São Paulo, São Paulo, 2016.

SANTOS, B. S. Democratizar o espaço, democratizar o território. Revista Punkto, 2013. Disponível em: <http://www.revistapunk to.com/2013/12/democratizar-oespaco-boaventurasousa.html > Acesso em 27 jan. 2014.

.Uma cartografia simbólica das representações sociais: Prolegômenos a uma concepção pós-moderna do direito.Espaço \& Debates, São Paulo, v. 11, 1991, pp.63-79, 1991.

SANTOS, R. E. O ensino de Geografia do Brasil e as relações raciais: reflexões a partir da lei 10.639. In: Diversidade, Espaço e Relações Étnico Raciais: O Negro na Geografia do Brasil. Belo Horizonte: Ed. Autêntica, 2007. 
- Sobre espacialidade das relações raciais:raça, racialidade e racismo no espaço urbano.In:Questões urbanas e racismo.Petrópolis, RJ:ABPN,2012.

SANTOS, M. O papel ativo da geografia, um manifesto. Publicação porocasião do XII Encontro Nacional de Geógrafos, Florianópolis,2000.

. Ser negro no Brasil. In: RIBEIRO, W.C (org.) O país distorcido: o Brasil, a globalização e a cidadania.São Paulo: Publifolha, 2002.

As cidades mutiladas. In: LENER, Júlio (org.).O preconceito.São Paulo: Imprensa Oficial do Estado,1996/1997.

O espaço do cidadão. São Paulo: Ed.Nobel, 1987.

Por uma Geografia cidadã: por uma Epistemologia da Existência.BoletimGaúcho de Geografia, Porto Alegre,n. 21, pp.7-192, 1996.

Por uma Geografia Nova: da crítica da Geografia a uma Geografia Crítica.São Paulo: Edusp, 2005.

SANTOS. G. E. Metropole, Cotidiano e Racismo: Morte e encarceramento da população Negra em São Paulo. Monografia (Trabalho de Graduação Integrado em Geografia) Faculdade de Filosofia, Letras e Ciências Humanas, Universidade de São Paulo, São Paulo, 2017.

SOUSA, N. S. Tornar-se negro: as vicissitudes do negro brasileiro em ascensão social. Rio de Janeiro: Edições Graal, 1983.

SACK, R. Human Territoriality: its theory an history. Cambridge:Cambridge University Press, 1986.

SANTUZA,A. S., PÁDUA, K. C.; SOUZA, A. X. "Pontos fora da curva": narrativas de professores negros da UFMG.In: PRAXEDES, V. L. et. al. (org.). Memória e percurso de professores negros e negras da UFMG. Belo Horizonte: Autêntica, 2009.

SAQUET, A. A abordagem territorial: considerações sobre a dialética do pensamento e do território.in:HEIDRICH, A. L. (org.).A emergência da multiterritorialidadee a ressign ificação da relação do humano com espaço.Canoas, RS: ULBRA/IUFRGS, 2008.

SILVA, P. S. Um projeto civilizatório e regenerador: análise sobre raça no projeto da Universidade de São Paulo (1900 -1940). Tese (Doutorado em Educação) - Faculdade de Educação, Universidade de São Paulo, São Paulo, 2016.

SILVA, M. J. Racismo à moda brasileira: raízes históricas: um novo nível de reflexão sobre a história do Brasil. $3^{a}$ ed. São Paulo: Anita Garibaldi, 1995.

SOUZA, M. L. O território: sobre espaço e poder, autonomia e desenvolvimento. In: CASTRO, I. et. al. (Org.). Geografia: Conceitos e temas. Rio de Janeiro: Bertrand Brasil, 1995. 
SCHUCMAN, L.V. Sim, nós somos racistas: estudo psicossocial da branquitude paulista.Psicologia \& Sociedade, Belo Horizonte, v. 26, n. 1, pp. 83-94,2014.

SCHWARCZ, L. M.O espetáculo das raças: cientistas, instituições e questões raciais no Brasil-1870-1930.São Paulo: Companhia das Letras,1993.

SIQUEIRA, J. S. A consciência negra da Universidade de São Paulo(1987 a 2016). Iniciação Cientifica em Educação - Faculdade de Educação, Universidade de São Paulo, São Paulo, 2017.

VAINER, C. B. Do corpo marcado ao território demarcado: uma leitura da transição para o trabalho livre como ponto de partida para uma história da mobilidade do trabalho no Brasil.Cadernos de Mig ração, São Paulo, n. 7, 2000.

VIEIRA, D.M. Territótios negros em Porto Alegre/Rs(1800-1970). Dissertação (Mestrado em Geografia) - UFRGS, Porto Alegre, 2017

TEIXEIRA, M. P. Negros na universidade: Identidade e trajetória de ascensão social no Rio de Janeiro. Rio de Janeiro: Pallas, 2003.

WITTER, J. S. USP 50 anos:Registro de um debate. $2^{\text {a }}$ Ed.São Paulo: EDUSP, 2006. 